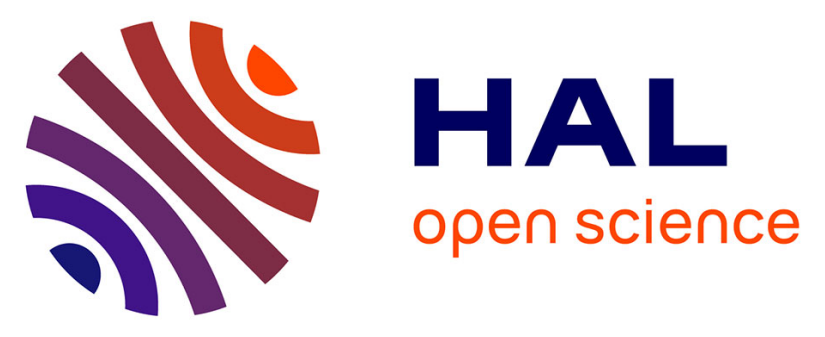

\title{
Latest Ordovician-earliest Silurian acritarchs and chitinozoans from subsurface samples in Jebel Asba, Kufra Basin, SE Libya
}

Bindra Thusu, Sayed Rasul, Florentin Paris, Guido Meinhold, James P. Howard, Youssef Abutarruma, Andrew G. Whitham

\section{To cite this version:}

Bindra Thusu, Sayed Rasul, Florentin Paris, Guido Meinhold, James P. Howard, et al.. Latest Ordovician-earliest Silurian acritarchs and chitinozoans from subsurface samples in Jebel Asba, Kufra Basin, SE Libya. Review of Palaeobotany and Palynology, 2013, 197, pp.90-118. 10.1016/j.revpalbo.2013.05.006 . insu-00843501

\section{HAL Id: insu-00843501 https://hal-insu.archives-ouvertes.fr/insu-00843501}

Submitted on 15 Jul 2013

HAL is a multi-disciplinary open access archive for the deposit and dissemination of scientific research documents, whether they are published or not. The documents may come from teaching and research institutions in France or abroad, or from public or private research centers.
L'archive ouverte pluridisciplinaire HAL, est destinée au dépôt et à la diffusion de documents scientifiques de niveau recherche, publiés ou non, émanant des établissements d'enseignement et de recherche français ou étrangers, des laboratoires publics ou privés. 


\section{Latest Ordovician-earliest Silurian acritarchs and chitinozoans from}

\section{2 subsurface samples in Jebel Asba, Kufra Basin, SE Libya}

3

4 Bindra Thusu ${ }^{1}$, Syed Rasul ${ }^{1}$, Florentin Paris ${ }^{2}$, Guido Meinhold ${ }^{3,4, *}$, James P. Howard ${ }^{3}$, Yousef

5 Abutarruma ${ }^{5}$, Andrew G. Whitham ${ }^{3}$

6

$7 \quad{ }^{1}$ Maghreb Petroleum Research Group, Department of Earth Sciences, University College

8 London, Gower Street, London WC1E 6BT, United Kingdom

$9{ }^{2}$ Rue des Jonquilles, 35235 Thorigné-Fouillard, France; Géosciences Rennes, CNRS UMR

10 6118, Université de Rennes 1, Rennes cedex, France

$11{ }^{3}$ CASP, University of Cambridge, West Building, 181 A Huntingdon Road, Cambridge CB3

$120 \mathrm{DH}$, United Kingdom

$13{ }^{4}$ Geowissenschaftliches Zentrum der Universität Göttingen, Abteilung

14 Sedimentologie/Umweltgeologie, Goldschmidtstraße 3, 37077 Göttingen, Germany

$15{ }^{5}$ Mellitah Oil \& Gas B.V., Dat Al Imad Complex Tower 5 Floor 13, P.O. Box 91651, Tripoli, 16 Libya

17

$18 *$ Corresponding author: Tel.: +49 551 393455; fax: +49 551397996.

19 E-mail address: guido.meinhold@geo.uni-goettingen.de (G. Meinhold)

20 


\section{Abstract}

35 Latest Ordovician-earliest Silurian Tanezzuft Formation shales recovered from core material of

36 the shallow borehole JA-2 drilled in Jebel Asba at the eastern margin of the Kufra Basin,

37 southeastern Libya, yielded well-diversified palynomorph assemblages with transparent and

38 brownish to yellowish vesicles and organic matter (visual kerogen Type 1 and 2) from depth

39 interval 46.20 to $67.82 \mathrm{~m}$. In addition, miospores including cryptospores, and Tasmanites sp.

40 ("Tasmanites with nodules"), scolecodonts, and a stratigraphically significant palaeo-marker, the

41 enigmatic, tubular organic structure Tortotubus protuberans, were also recorded frequently in 42 most samples. Kerogen colour based on miospores $(\mathrm{TAI}<3)$ and chitinozoan reflectance indicate 43 an immature facies for oil generation. The two uppermost samples (from $33.33 \mathrm{~m}$ and $46.20 \mathrm{~m}$ 44 depths) and the lowermost ones (from 67.92 to $73.21 \mathrm{~m}$ depth) contain rare palynomorphs and 45 other organic remains and have been partially affected by oxidation. Furthermore, palynological and palynofacies analysis was carried out on cuttings from an old well (UN-REMSA well), ca. $530 \mathrm{~m}$ towards the NNE from well JA-2. The composition of the organic residue is similar in both wells. However, the UN-REMSA well yields fairly numerous chitinozoans, scolecodonts and biofilms but lacks the "thread-like structures" and "Tasmanites with nodules" observed in well JA-2.

All the investigated samples in well JA-2 are dominated by a single chitinozoan species, Euconochitina moussegoudaensis Paris (in Le Hérissé et al., 2013). Based on correlation with

53 chitinozoan-bearing strata around the Ordovician-Silurian boundary, the analysed samples from 54 well JA-2 and from the UN-REMSA well are regarded as post-glacial, but still of either latest 55 Hirnantian age, or at least no younger than earliest Rhuddanian. A well-diversified acritarch, 
56 miospore and cryptospore assemblage recorded in well JA-2 supports a marginal marine

57 (nearshore) depositional environment. This assemblage is no older than earliest Rhuddanian yet

58 the latest Hirnantian age of the assemblage cannot be completely ruled out as our current

59 knowledge on the post-glacial, latest Hirnantian acritarch and miospore assemblages is poorly

60 documented in North Africa.

61

62 Keywords: biostratigraphy; acritarchs; chitinozoans; Hirnantian; Silurian, Gondwana; Libya

63

64 Research highlights

65 We describe palynomorphs from subsurface shales of SE Libya.

66 The shales are of latest Hirnantian-earliest Rhuddanian age.

67 The shales are immature for oil generation.

68 Dominant chitinozoan species Euconochitina moussegoudaensis Paris.

69 Discussion of the Ordovician-Silurian boundary.

70

71 1. Introduction

72

73 The precise location of the source rock horizons close to the Ordovician-Silurian boundary is an

74 important question for hydrocarbon exploration in northern Gondwana regions. In areas of

75 anoxic geological setting, typical "hot shale" horizons are easily identified by their peculiar

76 lithology (e.g., black shales), a sharp positive excursion of the gamma-ray curve in the well logs

77 and high total organic carbon (TOC) content (e.g., Lüning et al., 2000, 2005, 2006). These

78 characteristics can also be determined by the visual nature and the abundance of the organic 
matter including palynomorphs, animal remains and associated amorphous organic matter $(\mathrm{AOM})$

The main goal of the present study is to record for the first time moderately rich to rich assemblages of acritarchs, chitinozoans, miospores and cryptospores recovered from well JA-2 in Jebel Asba, Kufra Basin, drilled by CASP (formerly known as Cambridge Arctic Shelf Programme) in April-May 2009 (Fig. 1).

\section{Material and methods}

\subsection{Sampling}

Core samples from well JA-2 (geographic coordinates: $22^{\circ} 35^{\prime} 49.31^{\prime \prime} \mathrm{N}, 24^{\circ} 7^{\prime} 57.10^{\prime \prime} \mathrm{E}$ ) drilled in the Jebel Asba at the eastern margin of the Kufra Basin (Figs 1 and 2) and cuttings (single sample SJS0001) from a pile of drill cuttings surrounding the borehole collar of an abandoned well (geographic coordinates: $\left.22^{\circ} 36^{\prime} 4.52^{\prime \prime} \mathrm{N}, 24^{\circ} 8^{\prime} 4.67^{\prime \prime} \mathrm{E}\right)$, apparently drilled by REMSA (Repsol Exploración Murzuq S.A.), some $530 \mathrm{~m} \mathrm{NNE} \mathrm{of} \mathrm{well} \mathrm{JA-2} \mathrm{have} \mathrm{been} \mathrm{investigated} \mathrm{for}$ acritarchs and chitinozoans. However, we are not certain that the abandoned well was drilled by REMSA, and therefore we name it UN-REMSA well with UN standing for uncertain. Before starting the chemical processes, each core sample was observed under the binocular microscope in order to collect information on its grain size, petrology, and possible macrofossils. The degree of weathering of the rock sample was also evaluated as oxidation of the rock precludes the preservation of the organic matter (Table 1). This information is useful to interpret low chitinozoan abundances: low abundance in non-weathered and low-energy sediments is mainly caused by environmental conditions and the lack of palynomorphs in weathered or high-energy 
103 deposits, respectively, are due to oxidation of the organic matter, and to non-deposition of the

104 lighter particles such as acritarchs or chitinozoans.

In well JA-2 (Fig. 2), the lowermost core sample at $73.21 \mathrm{~m}$ depth is grey shale. Samples from 67.97 to $69.12 \mathrm{~m}$ show evidence of weathering (e.g., oxidation of pyrite crystals; brownish micas) in very fine light coloured sandstone and in whitish (altered?) shale. The uppermost processed samples $(33.33 \mathrm{~m}$ and $46.20 \mathrm{~m}$ ) also display evidence of weathering (i.e. beige colour

109 of the silty shale and oxidation of the organic matter). This alternation most likely corresponds to

110 the deepest part of the sub-Recent weathering profile developed in many Saharan regions. In the

111 interval $46.60-67.59 \mathrm{~m}$, the lithology is fairly constant and ranges from grey and greenish shale

112 to grey siltstone with micas. A lithological change is noticed between 67.59 and $67.82 \mathrm{~m}$ with

113 the occurrence of very fine sandstone. However, for the microfossils, a major change occurs at

$11467.97 \mathrm{~m}$ with a dramatic drop in abundance of the chitinozoans, possibly related to either the

115 oxidation, noticed in the core samples (Table 1), or to temporary emersion (e.g., during the latest

116 Hirnantian-earliest Rhuddanian post-glacial rebound), which permitted the weathering of the

117 older strata. Ground water circulation in a minor fault also might have caused oxidation of the

118 rock and of its organic matter between 67.82 and $69.12 \mathrm{~m}$. Because no biostratigraphical

119 information is available on the underlying strata, it is not possible to favour one or the other of

120 these hypotheses.

121 The cutting sample SJS0001 from the UN-REMSA well is susceptible to caving.

122 However, because no strong lithological disparity was noticed in the cuttings collected and

123 investigated, the drilled horizon represents likely dark grey silty shale, which is the most

124 common component of the sample.

125

126

\subsection{Sample preparation}


128 The core material was split into equal parts and prepared separately for acritarch and chitinozoan

129 analysis. For the acritarchs, the samples were treated according to standard palynological

130 preparation methods. A zinc bromide solution (specific gravity $2 \mathrm{~g} \mathrm{~cm}^{-3}$ ) was used for separation

131 of organic matter, which was then screened using a $15 \mu \mathrm{m}$ mesh for washing in order to separate

132 the larger organic-walled microfossils. If necessary, samples were also treated with nitric acid.

133 For chitinozoans, the processing technique developed in the palynological laboratory of Rennes

134 University (see Paris et al., 2012) was adopted. The palynological slides corresponding to the

135 illustrated material on Plates I to V are housed in the CASP Palaeontological Collection in

136 Cambridge, and the palynological slides corresponding to the illustrated material on Plates VI to

137 XII are housed in the collection of Rennes University under the repository numbers IGR 72951

138 to 72995.

139

140

\section{Palynological results}

141

142 Marine acritarchs, leiosphaerids, Tasmanites, land-derived plant elements (cryptospores,

143 miospores), and "thread-like structures" possibly related to cyanobacteria or to fungi in

144 association with nearshore chitinozoans, scolecodonts and eurypterid remains are reported in this

145 study (Tables 1 and 2). Large organic "blades" or "sheets", called "biofilm", are also present in

146 the organic residues.

147

148

3.1. Marine phytoplankton and land-derived plant element assemblages

149

150

3.1.1. Species from well JA-2 
152 The interval 33.33-69.12 m yielded rich to moderately rich assemblages of acritarchs (Plates I to

153 IV) dominated by Leiosphaeridia spp. The presence of Eupoikilofusa striatifera at $48.18 \mathrm{~m}$,

154 Moyeria cabbotti at $67.82 \mathrm{~m}$ and Leiosphaeridia acerscrabrella suggest an age no older than

155 Rhuddanian for this interval. Other accessory taxa present in the studied core samples include

156 Buedingiisphaeridium sp., Diexallophasis denticulata, Filisphaeridium sp., Geron cf. gracilis,

157 Tunisphaeiridium sp., Veryhachium europaeum, V. lairdii and V. trispinosum (Table 2).

158 The assemblage is dominated by miospores in the upper part of the interval 46.60-53.07

$159 \mathrm{~m}$. Tetrads and other cryptospores are dominant in the interval 48.18-67.82 m. Land-derived

160 spore tetrads are recorded in residues from various depths (see Tables 1 and 3) but mostly in the

161 interval 55.53-62.34 m. Miospores are represented by Ambitisporites dilutus,

162 Archaeozonotriletes chulus var. chulus and trilete spores. Cryptospores are represented by

163 Dyadospora murusdensa, Rugosphaera sp. and Tetrahedraletes medinensis. The presence of

164 these miospores and cryptospores are consistent with an early Silurian (Llandoverian,

165 Rhuddanian) age for the assemblage.

A few scolecodonts identified to the generic level (Plate XII, 1-2, 17) are present in the

167 upper part of the core (Table 1). These jaws of marine worms (polychaetes) occur in nearshore

168 as well as in pelagic deposits. Unusual thread-like and branched structures (Plate IX, 1, 6-8;

169 Plate XII, 9, 14, 18) of unknown biological affinities (plant, cyanobacteria or fungi?) are also

170 present in the organic residues (Tables 1 and 3). They are assigned to Tortotubus protuberans

171 Johnson, 1985, which seems restricted to latest Ordovician-earliest Llandovery nearshore

172 deposits in northern Gondwana localities (e.g., Chad, Libya, Oman, Saudi Arabia) and North

173 America (Pennsylvania). 
One of the peculiar characteristics of the palynological residues of JA-2 is the occurrence

175 of large "blades" or "sheets" (up to $1 \mathrm{~mm}$ thick) of amorphous organic matter (Plate IX, 2-5, 10;

176 Plate XII, 15-16). The chitinozoans and other palynomorphs are often adhesively associated with 177 amorphous organic matter (Plate IX, 9; Plate XI, 14-15, 17) as result of which the processes of

178 the Ancyrochitininae break frequently during sorting of the vesicles. These organic sheets are

179 composed of agglomerated minute particles of several $\mu \mathrm{m}$ in length and less than one $\mu \mathrm{m}$ thick

180 (Plate IX, 3 and 10). Pyrite framboids with $10 \mu \mathrm{m}$ in diameter are recorded, with the exception of 181 a sole specimen of about $500 \mathrm{~nm}$. Under transmitted light microscope, they appear as tiny black

182 spheres in the brownish to yellowish organic sheets. After oxidation with $\mathrm{HNO}_{3}$, the pyrite is

183 dissolved and the casts of the framboids are visible (Plate IX, 5 and 10). The organic sheets are

184 here called "biofilms", produced by algae or by bacteria. The organic matter in the northern

185 Gondwana "hot shale" has a similar structure with minute "flakes" of organic particles

186 adhesively clumped with the organic-walled microfossils. However, in the JA-2 well samples,

187 the AOM is concentrated in films coating the bedding plane, whereas in the classical "hot shale"

188 this organic matter is a major component of the sediment (up to $30 \%$ in some cases). This

189 organic matter may represent remnants of algae.

190

191 3.1.2. Species from the UN-REMSA well

192

193 Cutting samples (SJS0001) from the UN-REMSA well, located some $530 \mathrm{~m}$ NNE of JA-2,

194 yielded sparse acritarchs including Leiosphaeridia sp. and Eupoikilofusa striatifera (Table 2).

195 Land-derived palynomorphs include Ambitisporites dilutus and a spore tetrad along with

196 Tortotubus protuberance (Table 3). These taxa are also present in the core samples from JA-2. 
197 The sediment was deposited in a shallow marine environment. The sample is rich in AOM with

198 TAI $<3$, suggesting an immature kerogen with poor source potential.

199

3.2. Chitinozoan assemblages

3.2.1. Species from well $J A-2$

Most of the processed samples, except the two uppermost (33.33 and $46.20 \mathrm{~m}$ ) and the lowermost interval $(67.97-73.21 \mathrm{~m})$, which are likely to be affected by oxidation (see above), yield well-preserved chitinozoan assemblages with transparent and brownish to yellowish vesicles (Plates X-XI). They are poorly diversified and frequently monospecific assemblages (see Fig. 4). However, the chitinozoan abundance is fairly high as it exceeds 100 specimens per

209 gram of rock in half of the productive samples, and even reaches 430 specimens per gram of 210 rock at $57.58 \mathrm{~m}$ (Fig. 2; Table 1). In the other samples, the chitinozoan abundance ranges around 21160 to 80 specimens per gram of rock, except at 60.23 and $62.34 \mathrm{~m}$ depth where the abundance 212 drops significantly with 23 and 5 specimens respectively per gram of rock. It is worth noting that 213 eurypterid remains (Plate XII, 3-6) and Tasmanites tzadiensis Le Hérissé (in Le Hérissé et al., 214 2013) (Plate XII, 7-8, 11-13) are associated in these two samples (Table 1). This suggests 215 shallower environments with prominent agitation in which the sediment (siltstones with large 216 micas) becomes more mobile so that a selective sorting of the lighter particles occurs. All the investigated samples, except those from $67.59-67.97$ and $73.21 \mathrm{~m}$, are dominated

218 by a single species, Euconochitina moussegoudaensis Paris (in Le Hérissé et al., 2013), which 219 represents 95 to $100 \%$ of the recovered assemblages (Fig. 4). This species dominates also the 220 chitinozoan assemblages recorded in the Moussegouda shallow core in NW Chad (Le Hérissé et 
221 al., 2013) from grey silty shale intervals as in well JA-2. Furthermore, it has been described from 222 the Late Ordovician of Eastern Alborz in northern Iran (Ghavidel-Syooki, 2008).

224 Hérissé et al. 2013 and Plate VI, 4a-b, 8a-b; Plate VII, 5; Plate VIII, 3a-b, 4, 5a-b; Plate X, 1, $2255-8,10,12,14-16,18$; Plate XI, 16, 18-20). Its conical chamber has gently tapering flanks and a 226 flat to slightly convex bottom, which may be variously affected during the flattening (folded 227 inside or outside the chamber giving a more or less sharp aspect to the margin; see Plate X). No 228 mucron or basal scar has been observed on the available material. The sub-cylindrical neck 229 represents one third or less of the vesicle length, which ranges from ca. 100 to $200 \mu \mathrm{m}$. The 230 weak flexure is located at the base of prosome, near the junction of the rica on the chamber inner 231 wall (only visible on the transmitted light photos; Plate X). The wall surface is practically 232 smooth, but at high magnification, SEM observation reveals very tiny granules (Plate VI, 4b), 233 which are better expressed on, or near the margin (Plate VI, 8b). This species has no highly 234 distinctive features (i.e., ornamentation). However, it can be identified on large populations 235 allowing the appraisal of the intraspecific morphological variations. During the present study, elongate specimens sharing most of the characters of $E$.

237 moussegoudaensis Paris have been observed together with the typical form. These slender 238 individuals are tentatively separated from the main morphotype. They are referred to as 239 Euconochitina cf. moussegoudaensis Paris in Fig. 4 and on Plate X, 2-3, 9, 11, 19-20 and Plate $240 \mathrm{XI}, 3,5,11$. The vesicle length exceeds $200 \mu \mathrm{m}$ and may reach $230 \mu \mathrm{m}$. A weak constriction is 241 visible at a short distance above the margin (e.g., Plate X, 2, 19-20). It is not clear yet if these 242 elongate and slender vesicles correspond to the end forms within a polymorphic species or if 243 they represent a different species, with a stratigraphical range partly overlapping the total range 244 of E. moussegoudaensis Paris. 
Besides the dominating E. moussegoudaensis Paris are subordinate species restricted to

246 one or two samples. Calpichitina sp. (Plate X, 13) is restricted to one specimen recorded at 66.85

$247 \mathrm{~m}$ depth. The membranous remains visible on the margin are most likely residues of the biofilm

248 somehow glue the vesicle, and not part of a carina as in Pterochitina deichaii. Two species of Spinachitina - S. oulebsiri Paris et al. (2000) and Spinachitina verniersi

250 Vandenbroucke in Vandenbroucke et al. (2009) - are recorded in well JA-2. For the former, the 251 most abundant population is from $67.59 \mathrm{~m}$ (Fig. 4) but a few individuals are also recorded at 25267.21 and 67.40 m. Spinachitina oulebsiri (Plate VII, 1a-c, 3a-b, 4a-b, 6, 8 and 9a-c; Plate XI, 253 1, 6-10) has a conical chamber and a rather short sub-cylindrical neck (about one third of the 254 vesicle length) ended with a denticulate aperture (Plate VII, 9c). The margin bears a crown of ca. 25520 slender conical spines of up to $6 \mu \mathrm{m}$ length (Plate VII, 1b, 3b, 4b and 9b). Butcher (2009, p. 256 600) included S. oulebsiri in the synonymy list of S. fragilis, which is the index species for the 257 first Silurian chitinozoan biozone (Verniers et al., 1995). Even if they have close silhouettes, we 258 do not consider the two species as synonyms. This is in agreement with Vandenbroucke et al. 259 (2009) who reported S. oulebsiri from South Africa (see below). Indeed, S. oulebsiri has not the 260 conspicuous shoulder of the specimens Butcher assigned to S. fragilis from depth $42.50 \mathrm{~m}$ in 261 BG-14 in Jordan. Moreover, the populations of S. oulebsiri known in various localities from 262 Algeria (Paris et al., 2000; F. Paris, unpublished data) and South Africa (Vandenbroucke et al., $2632009)$ do not include large specimens $(>250 \mu \mathrm{m})$ as known in S. fragilis. Based on the discussion 264 below, S. oulebsiri ranges from the late Hirnantian to possibly earliest Rhuddanian (see Fig. 5). 265 Poorly preserved individuals from $62.34 \mathrm{~m}$ are tentatively referred to $S$. sp. aff. oulebsiri. In well JA-2 (Fig. 4), Spinachitina verniersi Vandenbroucke (in Vandenbroucke et al., 267 2009) (Plate VI, 3a-b; Plate VII, 2a-b) is fairly abundant at $67.59 \mathrm{~m}$ and is represented by a few 268 individuals at $65.74 \mathrm{~m}$ (see Fig. 4). This species, first described from the Soom Shale in South 
269 Africa (Vandenbroucke et al., 2009), has a vesicle very close to that of S. oulebsiri and even to 270 that of E. moussegoudaensis Paris. However, it is clearly distinguished from S. oulebsiri by the 271 design of the crown of ornaments running on its margin (more densely spaced and irregular 272 granules or blunt spines) (see Plate VII, 2a). Closely related specimens (S. cf. verniersi; Plate XI, 273 4) or more questionable individuals referred to as ?S. verniersi (Plate VI, $1 \mathrm{a}-\mathrm{b}, 2 \mathrm{a}-\mathrm{b}, 6 \mathrm{a}-\mathrm{b}$, $2747 \mathrm{a}-\mathrm{b}$; Plate VII, 7) due to a poor preservation of the crown on the margin are scattered from $27555.53 \mathrm{~m}$ depth to $67.82 \mathrm{~m}$ depth in well JA-2 (Fig. 4). S. verniersi does not benefit yet from an 276 accurate independent calibration by means of graptolites. However, in South Africa its FAD 277 (First Appearance Datum) is in the Soom Shale Formation, i.e. just above the last Hirnantian 278 glacial deposits (see discussion in Vandenbroucke et al., 2009). In Algeria, it also coexists with 279 S. oulebsiri in the M'Kratta Formation above the Hirnantian diamictites of the Hassi el Hadjar 280 Formation (see discussion in Paris et al., 2000). S. verniersi is also recorded in the cuttings from 281 the UN-REMSA well (Plate VIII, $6 \mathrm{a}-\mathrm{c}, 9 \mathrm{a}-\mathrm{b}, 10 \mathrm{a}-\mathrm{b}$ ) where it occurs in association with $E$. 282 moussegoudaensis Paris.

The Ancyrochitininae, abundant at $67.82 \mathrm{~m}$ depth, are present sporadically. Plectochitina 284 sp. (Fig. 4) is another form kept in open nomenclature because of its poor preservation. They 285 belong possibly to Plectochitina cf. longispina (Achab, 1978), which is the dominating species 286 at $67.82 \mathrm{~m}$ depth (Plate VI, 5, 10; Plate XI, 13-15, 17). These specimens are assigned to 287 Plectochitina rather than to Ancyrochitina because of the cell-like structure of their long 288 processes (Plate X, 15 and 17). The individuals recorded at $67.82 \mathrm{~m}$ depth are rather small, e.g. 289 vesicle length ranging from 100 to $120 \mu \mathrm{m}$. The length of the processes is about 40 to $60 \mu \mathrm{m}$. 290 These values are very close to the measurements of Ancyrochitina longispina described by 291 Achab (1978) in the Ellis Bay Formation of Anticosti Island, Eastern Canada. The Libyan and 292 the Canadian specimens have processes with similar branching. The main difference between the 
two populations is the less developed branching of the Libyan individuals ( 2 times branching as

294 a maximum). According to Achab (1978) and Soufiane and Achab (2000), A. longispina is

295 restricted to the lower member of the Ellis Bay Formation assigned to the early Hirnantian (i.e.

296 extraordinarius graptolite Zone) by Melchin (2008). Recently, Butcher (2009) published a form

297 he called Ancyrochitina sp. C, which displays most of the features of the individuals identified

298 here as Plectochitina cf. longispina, i.e. short vesicle. However, the form illustrated by Butcher

299 (2009) from BG-14 in Jordan is from the upper ascensus-acuminatus Biozone (early

300 Rhuddanian). Obviously, there is an urgent need of clarification of the Ancyrochitininae close to 301 the Ordovician-Silurian boundary, especially the forms with long processes.

\subsubsection{Species from the UN-REMSA well}

305 The composition of its organic residue is very similar to most of the residues recovered from 306 well JA-2. It includes fairly numerous chitinozoans, scolecodonts and biofilms. However, neither 307 "thread-like structures", nor "Tasmanites with nodules" (i.e. Tasmanites tzadiensis Le Hérissé in 308 Le Hérissé et al. 2013) have been observed in this residue.

309 The cuttings from the UN-REMSA well (sample SJS0001) yield a chitinozoan assemblage very

310 close to that observed in well JA-2. Euconochitina moussegoudaensis Paris (Plate VIII, 2a-b; 4,

$3115 \mathrm{a}-\mathrm{b})$ is again the dominant species. It is accompanied by rare Cyathochitina caputoi Da Costa, 3121971 (Plate VIII, 1). C. caputoi (the thick carina form), which is usually very abundant close to 313 the Ordovician-Silurian boundary is not observed in well JA-2. A few Spinachitina verniersi 314 (Plate VIII, 6a-c, 9a-b, 10a-b) and damaged Ancyrochitininae (Plate VIII, 7-8) (broken 315 processes do not allow any specific assignment) are also present in this assemblage and are 316 assigned to the latest Hirnantian-earliest Rhuddanian (see Fig. 5). 
320 Visual kerogen analysis using transmitted light microscopy was carried out on 23 samples from

321 the interval 33.33-73.21 m (Table 4). The analysis results are summarised in Figure 2. The

322 interval $33.33-46.20 \mathrm{~m}$ is completely dominated by semi-structured (Type 3), vitrinite-like

323 material. No acritarchs or miospores were recorded in this interval. The interval $46.60-67.40 \mathrm{~m}$

324 is generally dominated by AOM (Type 1) but semi-structured, vitrinite-like material continues to

325 show its presence throughout the interval (see Appendix A). A high number of acritarchs along

326 with miospores/cryptospores are also documented. Leiospheridia spp. dominate in numbers, and

327 spiny acanthomorph acritarchs are low in numbers. The interval $67.59-73.21 \mathrm{~m}$, with the

328 exception of core at $69.92 \mathrm{~m}$ depth, in which AOM dominates, is abundant in semi-structured,

329 vitrinite-like material.

Based on the colour of the miospores, the thermal alteration index (TAI) (Staplin, 1969)

331 is less than 3, indicating an immature palynofacies for oil generation. Acritarchs and

332 cryptospores are consistently pale and light yellow in colour, which probably indicates a lack of

333 thermal alteration. Chitinozoan reflectance yielded $\mathrm{R}_{\mathrm{ch}}$ values of about $0.6 \%$ (Table 5) which

334 equals vitrinite reflectance $\left(\mathrm{R}_{\mathrm{v}}\right)$ values of about $0.4 \%$ when using the equation of Tricker et al.

335 (1992). Sediment with $\mathrm{R}_{\mathrm{v}}$ of $0.4 \%$ is immature for oil generation, supporting the TAI

336 interpretation.

338 4. Biostratigraphy, palaeoecology and regional correlation 
342 The acritarchs assemblage is dominated by thin-walled Leiosphaeridia spp. often in clusters.

343 Dorning (1981) found dominance of thin-walled leiosphaerids in the shallow marine Silurian

344 (Ludlovian) sequence of the Welsh Borderland. The presence of land-derived vitrinite-like

345 macerals and miospores-cryptospores is also indicative of a marginal marine (nearshore)

346 depositional environment for the entire sequence of the studied well JA-2, although the interval

$347 \quad 33.33-60.23 \mathrm{~m}$ does seem much closer to land with the dominance of land-derived plant

348 remains.

349 In the late Silurian of the Ghadamis Basin, Al-Ameri (1983) erected six distinct types of

350 palynofacies of which four contained acritarchs indicating increasing distance from the

351 shoreline. Hill and Molyneux (1988) recognised two Llandoverian palynofacies assemblages in

352 NE Libya. Their southern assemblage located in southern Cyrenaica, north of the present study

353 area, was also dominated by leiosphaerids. Hill and Molyneux (1988) consider their acritarch

354 assemblage comparable most closely to Palynofacies 3 of Al-Ameri (1983), which is interpreted

355 as inner neritic.

356 The studied assemblage is also comparable to the land-derived palynoflora (miospores-

357 cryptospores and organic structures) of early Silurian (Rhuddanian) age from the Tuscarora

358 Formation in central Pennsylvania, USA (Johnson, 1985). Based on these comparisons the

359 present assemblage was probably deposited closer to the shoreline.

361 4.1.1. Libya

363 Acritarch assemblages recorded in well JA-2 are similar to those from other basins in North 364 Africa, the Middle East, and North America (Fig. 3). 
366 Kufra Basin

368 Grignani et al. (1991) established a zonation of the early Silurian Assemblage C based on the

369 chitinozoan Ancyrochitina ancyrea. However, the authors reported no early Silurian acritarchs.

370 The marker acritarchs such as Villosacapsula irrorata, V. setosapellicula and Veryhachium

371 subglobosum restricted to the Late Ordovician (Caradoc-Ashgill) were reported by Grignani et

372 al. (1991) and by Thusu et al. (2007) from cutting samples from Jebel Dalma.

Murzuq Basin

Paris et al. (2012) reported an early Llandovery palynomorph assemblage from well CDEG-2a in Dor el Gussa and recorded palynomorph species which are also present in the present study including Buedingiisphaeridium sp., Diexallophasis denticulate, Eupoikilofusa striatifera, Leiofusa estrecha, Veryhachium. europaeum, V. trispinosum, Dyodospora murusdensa and Tetrahedraletes medinensis.

Ghadamis Basin

384 Richardson and Ioannides (1973) reported a rich assemblage of Silurian acritarchs from two 385 wells, C1-34 and B2-34, from the Akakus and Tanezzuft formations in the Ghadamis Basin. The 386 recorded species in common with the present assemblage include Eupoikilofusa striatifera, 387 Veryhachium trispinosum, Diexallophasis denticulata, Leiosphaeridia acerscabrella, Leiofusa 388 estrecha, Geron cf. gracilis, Tetrahedraletes medinensis and Dyadospora murusdensa. 
$390 \quad$ Northeast Libya, Cyrenaica

392 Hill et al. (1985), Hill and Molyneux (1988) and Richardson (1988) recorded early Silurian

393 (Llandoverian) acritarchs from the Cyrenaica Platform. Several species recorded from Cyrenaica

394 are common with the present assemblage and include Eupoikilofusa striatifera, Diexallophasis

395 denticulata, Tunisphaeridium sp., and Buedingiisphaeridium sp..

Le Hérissé et al. (2013) reported latest Ordovician-earliest Silurian palynological assemblages

400 from the Moussegouda shallow borehole $\left(21^{\circ} 40^{\prime} \mathrm{N}, 18^{\circ} 36^{\prime} \mathrm{E}\right)$ drilled in the Erdi Basin, northern

401 Chad in the early 1960s. The Erdi Basin and the Mourdi Basin in northwest Sudan are

402 considered to be the southern extensions of the Kufra Basin to the north in Libya.

403 The presence of several stratigraphically restricted acritarchs reported from core 9 (220-221A

$404 \mathrm{~m})$ from the Moussegouda borehole such as Neoveryhachium sp. A, Veryhachium subglobosum 405 and Villosacapsula setosapellicula clearly support an age no younger than Late Ashgill for this 406 interval. V. subglobosum and V. setosapellicula were also recorded by Grignani et al. (1991) in 407 their assemblage ' $\mathrm{B}$ ' in the Kufra Basin. None of these species were recorded in our study. The 408 absence (except in the basal part) of these species together with the common presence of 409 Tasmanites tzadiaensis Le Hérissé et al. (2013) and many reported acritarchs and chitinozoans, 410 cryptospores and miospores in cores 8-2 from the Moussegouda well in Chad and those in well 411 JA-2 in Libya support their close chronostratigraphic and ecological similarities. 
412 The oldest recorded early Silurian (late Rhuddanian) local Biozone LI1 was first reported by Hill

413 and Molyneaux (1988) from an exploratory well (E1-81) in Cyrenaica northeast Libya and

414 recently by Paris et al. (2012) from a shallow borehole (CDEG-2) in Dor el Gussa, eastern

415 Murzuq Basin. In both areas, the incoming of marker species Diexallophasis caperoradiola,

416 Multiplicisphaeridium fisherii and Oppilatala eoplanktonica clearly support a Late Rhuddanian

417 age. None of these species were either recorded in Le Hérissé et al. (2013) in the Moussegouda

418 well or in the present study in the JA-2 well. Based on these observations, it is inferred that the

419 post-Ashgillian interval in the Moussegouda well (cores 8-2) and in well JA-2 may represent a

420 time interval between the latest Ordovician and earliest Silurian. However, the presence of

421 Geron cf. gracilis, Moyeria cabotii, Tunisphaeridium sp., Ambitisporites dilutus and

422 Archaeozonotriletes chulus var. chulus and Tortotubus protuberans in well JA-2 does appear to

423 demonstrate an early Silurian age for the JA-2 assemblage. Furthermore, we cannot rule out the

424 extension of the well JA-2 sequence to the post-glacial latest Hirnantian because the post-glacial

425 latest Hirnantian acritarch and miospore assemblage is poorly documented in North Africa.

426 The palynomorph content in both wells is supportive of a marginal marine (nearshore)

427 environment and may represent a post-glacial pre-Tanezzuft Formation (sensu stricto)

428 sedimentary sequence.

\subsubsection{Algeria}

432 Jardine et al. (1974) recorded early Silurian acritarch assemblages from the Algerian Sahara and

433 established Palynozones G1 and G2. Species common to the Algerian and present assemblage

434 include Diexallophasis denticulate, Eupoikilofusa striatifera, Leiofusa estrecha and

435 Veryhachium trispinosum. 
439 Le Hérissé et al. (1995) recorded early Silurian (Llandovery, Rhuddanian and Aeronian)

440 palynomorphs assemblage from Saudi Arabia. They recorded Buedingiisphaeridium sp., D.

441 denticulata, E. striatifera, Filisphaeridium sp., Geron sp., Moyeria cabottii and Tunisphaeridium 442 sp..

\subsubsection{Jordan}

446 Keegan et al. (1990) recorded early Silurian palynomorphs from two exploration wells of the

447 Hashemite Kingdom of Jordan. The morphotypes Geron gracilis, D. murusdensa, Ambitisporites 448 dilutus and Archaeozonotriletes chulus var. chulus are present in zone JS-3 (early Llandoverian) 449 of Jordan and are also recorded in the present study.

453 The studied assemblage in well JA-2 is closely comparable with the early Silurian (Rhuddanian) 454 assemblage from the Tuscarora Formation in central Pennsylvania, USA (Johnson, 1985).

455 Common species include L. acerscabrella, T. mediensis, A. dilutus, Rugosphaera $\mathrm{cf}$.

456 tuscarorensis and Tortotubus protuberans. 
460 Available data on chitinozoans from the Ordovician-Silurian boundary increased significantly

461 during the last ten years with the work of Bourahrouh (2002) (data on Algeria, Morocco, western

462 France and Czech Republic) and the papers of Vandenbroucke et al. (2009) on the chitinozoans

463 from the Soom Shale of South Africa, and of Butcher (2009) on those of the Mudawwara Shale

464 Formation in Jordan. A few new species are erected in these contributions. However, an

465 extensive taxonomical study of many undescribed new forms from the Late Ordovician-early

466 Silurian of northern Gondwana regions, based on large populations, is now urgently needed.

467 Independent biostratigraphical control by means of graptolites is now available for some

468 chitinozoan-bearing sections, e.g. Nseirat section, Mauritania (Underwood et al., 1998; Legrand,

469 2009), Jordan (Lüning et al., 2006; Loydell, 2007, 2012), Les Fresnaies section, southern

470 Brittany, France (Piçarra et al., 2009), and Hlasna Treban, Czech Republic (Štorch, 1996; Štorch

471 and Loydell, 1996). All these data now allow a reassessment of the chitinozoan assemblages

472 formerly described in NE Libya by Molyneux and Paris (1985) and by Paris (1988).

473 The occurrence of chitinozoans throughout the penetrated sequence in JA-2 (except the barren

474 lowermost samples; see above) clearly indicates a marine deposit. The rather low diversity of the 475 recorded assemblages, in spite of high abundance (up to 415 specimens per gram of rock), is 476 compatible with deposition in a rather proximal setting to the shoreline. This is consistent also 477 with the occurrence of land-derived cryptospores and miospores in association with vitrinite-like 478 organic matter in the residues. The presence of eurypterids (Plate XII, 3-6) is also in favour of 479 environments not very far from the shoreline as these animals are regarded as nearshore (e.g., 480 Jones and Kjellesvig-Waering, 1985), and in some cases occasionally terrestrial organisms 481 (especially in the late Silurian) (e.g., Braddy, 2001). The occurrence of Tortotubus protuberans 482 (Plate XII, 9, 14, 18) provides an additional indication of deposition fairly close to the shoreline, 
483 as this enigmatic microfossil is usually reported from shallow to terrestrial environments at the

484 Ordovician-Silurian boundary (e.g., Le Hérissé et al., 2013).

\subsection{Ordovician-Silurian boundary}

The definition of the base of the Silurian, and thus of the Rhuddanian Stage is a critical point for the calibration of the latest Ordovician-earliest Silurian chitinozoan assemblages. The

Ordovician-Silurian boundary first moved from its historical position at the base of the

491 persculptus Biozone, to the base of the succeeding acuminatus Biozone, with the GSSP of the

492 base of the Silurian defined at Dob's Linn in Scotland (see Williams and Ingham, 1989). The

493 basal Silurian acuminatus Biozone at Dob's Linn was subsequently subdivided into a lower

494 Akidograptus ascensus Biozone and a higher, more restricted Parakidograptus acuminatus

495 Biozone (Melchin and Williams, 2000). As a consequence, the base of the Silurian (base of the

496 Rhuddanian) is now defined by the first appearance of $A$. ascensus. This definition was ratified

497 by the International Subcomission on Silurian Stratigraphy (2007). Moreover, recent revisions of 498 graptolites from the ascensus-acuminatus Biozone (e.g., Loydell, 2007, 2012, and references 499 therein) confirm the three-fold divisions of this biozone by Štorch (1996) into lower, middle and 500 upper subzones. In this scheme (see Loydell, 2007, p. 10), A. ascensus ranges in the lower and 501 the middle subzones. All these successive changes had consequences on the accurate dating of 502 the chitinozoan biozones around the Ordovician-Silurian boundary, as there are no direct ties 503 with the GSSP at Dob's Linn (no workable chitinozoan assemblages are available yet; see

504 Verniers and Vandenbroucke, 2006). Delabroye and Vecoli (2010) briefly reviewed the 505 biostratigraphical inconsistencies persisting in the main diagnostic fossil groups close to the 506 Ordovician-Silurian boundary. 
510 Continuous chitinozoan-bearing strata of latest Ordovician to early Silurian age, i.e. not

511 disturbed by Hirnantian glacial events, are very rare in northern Gondwana regions (including 512 peri-Gondwana Europe, sensu Štorch, 1996). At a few localities this boundary can be located 513 with the greatest precision, for example, in the Nseirat section in the Hodh area (Mauritania), 514 which yielded associated abundant graptolites (Underwood et al., 1998; Legrand, 2009) and 515 chitinozoans (Paris et al., 1998; F. Paris, unpublished data). The Hlasna Treban section in the 516 Prague Basin (Czech Republic) also yielded well studied graptolites (Štorch, 1996; Štorch and 517 Loydell, 1996) and chitinozoan data (Dufka and Fatka, 1993; Bourahrouh, 2002). Another 518 section is at les Fresnaies, Ancenis Basin, western France, where Hirnantian chitinozoan-bearing 519 diamictites (Bourahrouh, 2002; F. Paris, unpublished data) are overlain by Rhuddanian black 520 shale with associated graptolites and chitinozoans (Bourahrouh, 2002; Piçarra et al., 2002; 521 Piçarra et al., 2009; F. Paris, unpublished data). The Ordovician-Silurian boundary can also be 522 located with the greatest precision in well BG-14 in southern Jordan where graptolites (Loydell, 523 2007) and chitinozoan (Butcher, 2009) have been studied. In southern Saudi Arabia chitinozoans 524 occur in the MKSR-1 well, just below and within graptolite-bearing black shale assigned to the 525 early Rhuddanian (Paris et al., 1995). Other important controls should be obtained from the 526 graptolite-bearing sequence in the E1-NC174 core in the Murzuq Basin (Libya) as chitinozoans 527 are also reported (Butcher, 2012) with abundant early Rhuddanian graptolites (Loydell, 2012).

528 The concurrent ranges of the chitinozoans and graptolites in these sections are used here for 529 more precise dating of numerous previously published chitinozoan assemblages close to the 530 Ordovician-Silurian boundary (Fig. 5). 
In the present study on core samples from JA-2, the comparison focuses chiefly on the

532 chitinozoan data available for Libya, with a particular attention paid to the chitinozoan

533 assemblages from the Kufra Basin, e.g. KW-2 core-drill (Grignani et al., 1991; Le Hérissé et al.,

534 2013; F. Paris, unpublished data), cores from wells A1-NC43 and B1-NC43 (Grignani et al.,

535 1991), and cuttings from H6000 and W5174 (Paris et al., 2008) (Fig. 5). Correlation is also

536 proposed with other Libyan regions, e.g. well CDEG-2a in the eastern Murzuq Basin (Paris et

537 al., 2012). The Silurian chitinozoans of Al-Ameri (1989) from Western Libya, however, are not

538 discussed here as they correspond to assemblages younger than the material recovered from the

539 sub-surface of the Kufra Basin. Older data from Cyrenaica (Molyneux and Paris, 1985; Paris,

540 1988), which did not benefit from an independent calibration in terms of graptolite biozones, can

541 now be updated. The correlations are extended to cores in other countries, e.g. Moussegouda,

542 northern Chad (Le Hérissé et al., 2004, 2013).

543 In Moussegouda, the occurrence of glacio-marine deposits with typical Late Ordovician

544 chitinozoans and acritarchs ca. $15 \mathrm{~m}$ below the first E. moussegoudaensis chitinozoan

545 assemblage must be stressed, as this demonstrates that the E. moussegoudaensis dominated

546 assemblage is clearly post-glacial. In well KW-2, E. moussegoudaensis occurs in the shale

547 referred to the Tanezzuft Formation (Le Hérissé et al., 2013). Below $54 \mathrm{~m}$ of this Tanezzuft

548 Formation shale, the well penetrated sandstone of the Mamuniyat Formation for $7 \mathrm{~m}$. No

549 chitinozoans are reported from this sandy member but typical latest Ordovician chitinozoan

550 assemblages are present in the neighbouring wells of A1-NC43 (core 3, Mamuniyat Formation)

551 and B1-NC43 (core 5; but supposed to belong to the Tanezzuft Formation in Grignani et al.,

552 1991). The lithostratigraphic position of the latter core sample, however, is confusing (see

553 discussion in Grignani et al., 1991, p. 1163). No graptolites have been identified in JA-2 or in

554 Moussegouda, but Grignani et al. (1991) reported "Climacograptus medius" (now 
Normalograptus medius) in the KW-2 cores. If the identification is correct, this means that the

556 corresponding samples can be of late Hirnantian as well as of Rhuddanian age as this species

557 ranges across the Ordovician-Silurian boundary (see Loydell, 2007, text in fig. 6). In areas of

558 JA-2 and KW-2, we do not have unweathered material from the overlying formations. In

559 Moussegouda, the shale sequence with the moussegoudaensis chitinozoan assemblage is directly

560 overlain by barren white sandstone referred to the Akakus Formation. No biostratigraphical data

561 are available in the Silurian part of A1-NC43 and B1-NC43. Consequently, the top of the

562 moussegoudaensis assemblage is not constrained in the Kufra Basin, even when this structure is

563 extended to northern Chad.

The ranges of S. oulebsiri and S. verniersi, two taxa represented in the moussegoudaensis assemblage, have been used to better constrain its chronostratigraphic assignment. S. oulebsiri

566 ranges in late Hirnantian post-glacial deposits, especially in the Nseirat section (Mauritania),

567 where it coexists briefly with Belonechitina pseudarabiensis and Cyathochitina caputoi. The

568 latter have their Last Appearance Datum (LAD) higher up in the section in the well-dated upper

569 ascensus-acuminatus Biozone of early Rhuddanian age. The lower part of the Nseirat section

570 (with S. oulebsiri) yields abundant Normalograptus graptolites attributed to the persculptus

571 Biozone (Underwood et al., 1998), i.e. of late Hirnantian age. However, the specific assignment

572 of these Normalograptus have been recently contested by Loydell (2007) who rejected the

573 specimens of N. persculptus illustrated by Underwood et al. (1998) from his well-documented

574 synonymy list for N. persculptus (Loydell, 2007, p. 43). Because the durations of the related glacial events are significantly shorter (ca. $10 \mathrm{ky}$ )

576 than the range of the recorded chitinozoan species (ca. 1 Ma or more), the Hirnantian glacial

577 climax can be regarded as isochronous at the scale of the northern Gondwana chitinozoan

578 biozonations. Indeed, several typical Late Katian species, e.g. Calpichitina lenticularis, 
580 et al., 2000, and references therein) range through the Hirnantian, up to the end of the main

581 melting phase of the ice cap, in the latest Hirnantian. Fortunately, some taxa have a more

582 restricted range and proved to be helpful for subdividing the latest Ordovician. Tanuchitina

583 elongata, the index species of the next to last Ordovician chitinozoan biozone (Paris, 1990) has

584 its FAD before the first drastic sea level fall characterising the beginning of the Hirnantian

585 glacial climax. This FAD is located just above the base of the Hirnantian as documented in the 586 Anti-Atlas, Morocco (Loi et al., 2010) and in the Prague Basin by Bourahrouh (2002) where $T$.

587 elongata is recorded in association with Normalograptus osjuensis. The latter graptolite is

588 regarded as slightly preceding the FAD of $N$. extraordinarius, the index graptolite of the base of

589 the "new" Hirnantian stage (see Chen et al., 2000, 2006) and thus T. elongata begins also just

590 below the base of the Hirnantian. The species is recorded up to the uppermost Kosov Formation

591 (Hirnantian) in the Prague Basin (Bourahrouh, 2002) where N. persculptus is present (Štorch and 592 Loydell, 1996). The total range of T. elongata is therefore latest Katian-late Hirnantian. At present, Spinachitina oulebsiri Biozone is the last Ordovician chitinozoan biozone in 594 the northern Gondwana biozonation (Webby et al., 2004). This species coexists for a time with 595 the last typical Ordovician chitinozoan species (see above) and thus its lower part is late 596 Hirnantian in age. The LAD of S. oulebsiri is documented in the lower part of the Nseirat section 597 (up to MSE-10) where it is associated with other chitinozoans with dominating Cyathochitina 598 caputoi and rare Belonechitina pseudarabiensis. This chitinozoan assemblage coexists with 599 numerous Normalograptus assigned to N. persculptus by Underwood et al. (1998), but not 600 included in the synonymy list of this species proposed by Loydell (2007). Additional 601 information is available from the MKSR-1 well (southern Saudi Arabia) where S. oulebsiri is 602 restricted to strata below the 'hot shale' horizon yielding numerous $C$. caputoi associated with 
603 graptolites of the acuminatus Zone (Paris et al., 1995, and discussion in Paris et al., 2013).

604 According to the graptolites, S. oulebsiri may therefore extend into the uppermost Hirnantian or 605 the lowermost Rhuddanian. Based on the synonymy proposed by Vandenbroucke et al. (2009), 606 S. oulebsiri is present in the United Kingdom (Vandenbroucke et al., 2005; Vandenbroucke, 607 2008). This species is reported from other localities devoid of accurate independent age control, 608 e.g. Soom Shale in South Africa (Vandenbroucke et al., 2009), several wells in Algeria, 609 including N1-2 (Paris et al., 2000), and sections in Argentina (De La Puente, 2009). It is also 610 present in JA-2 in SE Libya (see Fig. 4). In these localities, it is worth noting that S. oulebsiri 611 without the typical Late Ordovician species but associated with $S$. verniersi, occurs in post612 glacial deposits. This confirms that the climax of the Late Ordovician glaciation ended within the 613 persculptus Biozone.

614 Slightly higher in the Nseirat section (from NSE-11 to NSE-18) B. pseudarabiensis and 615 C. caputoi dominate the chitinozoan assemblages. They are associated with $S$. debbajae in strata 616 referred to the lower-middle subzone of the ascensus-acuminatus Biozone based on its 617 graptolite content (Underwood et al., 1998) and on the comments provided by Loydell (2007). 618 From NSE-18 onward, B. pseudarabiensis is associated with S. fragilis (morphotype with a 619 shoulder) and with graptolites of the ascensus-acuminatus Biozone from NSE-18. A similar 620 situation occurs also in Jordan (Butcher, 2009), in BG-14 core sample at $42.5 \mathrm{~m}$ depth assigned 621 by Loydell (2007) to the upper subzone ascensus-acuminatus Biozone. In the Les Fesnaies 622 section, western France (Bourahrouh, 2002; F. Paris, unpublished data), and in Hlasna Treban 623 section, Czech Republic (Dufka and Fatka, 1993; Bourahrouh, 2002) identical S. fragilis 624 specimens are associated with graptolites of the ascensus-acuminatus graptolite Biozone 625 described respectively by Piçarra et al. (2009) and by Štorch (1996). 
In Libya, in the Murzuq Basin, a chitinozoan assemblage similar to that of the upper

627 middle part of the Nseirat section, i.e. S. fragilis "with shoulder" associated with

628 Ancyrochitininae specimens with long branched processes (provisionally identified as $A$. cf.

629 ramosaspina) is reported from the interval $47.48-50.64 \mathrm{~m}$ (core 20 to core 23 ) in well CDGE-2a

630 (see Paris et al., 2012). In the Kufra Basin, in cuttings samples (W5174 and H6000) abundant $B$.

631 pseudarabiensis coexist with Ancyrochitininae (long processes branched at their distal end,

632 provisionally referred to as $A$. gr. ancyrea in Paris et al. (2008a). Based on the chitinozoan data

633 from Jordan newly published by Butcher (2009) on BG-14 core samples accurately dated by

634 graptolites (Loydell, 2007), the two Kufra assemblages from W5174 and H6000 can be

635 correlated with the upper part of the ascensus-acuminatus graptolite Biozone of Jordan, where

636 S. fragilis is no longer present (Butcher, 2009, text in fig. 7).

The re-evaluation of previous chitinozoans from Libya enables more accurate dates for 638 assemblages. For instance, the chitinozoans recovered from JI-81A, E1-81 and A1-81 wells of 639 southern Cyrenaica (Molyneux and Paris, 1985; Hill et al., 1985; Paris, 1988) are updated with 640 regards to the range of the chitinozoan key species selected in the present report (Fig. 5). In well $641 \mathrm{~J} 1-81 \mathrm{~A}$, cuttings from $12150 \mathrm{ft}$ to $13240 \mathrm{ft}$, yielded caved specimens of $S$. debbajae, S. oulebsiri, 642 and E. moussegoudaensis mixed with well-characterised in-situ Hirnantian species. This means 643 that below the Middle Devonian, and above the Upper Ordovician strata, this well penetrated 644 Rhuddanian deposits (see stratigraphical interpretation on Figure 5). In well E1-81, the 645 Ordovician-Silurian beds seem rather better developed, as there is a large interval of ca. $100 \mathrm{~m}$ 646 separating core 4 of early Rhuddanian age (abundant Sphaerochitina solitudina consistent with 647 the upper subzone of the ascensus-accuminatus Biozone), from core 5 of Hirnantian age 648 (elongata Biozone) (Fig. 5). 


\section{Conclusions}

651

652 The chitinozoan assemblages recovered from the $35 \mathrm{~m}$ thick shaly to silty sequence in well JA-2

653 are characterised by dominant Euconochitina moussegoudaensis and by the sporadic, but

654 stratigraphically important presence of Spinachitina oulebsiri, S. verniersi, and highly branched

655 Angochitininae. These characteristics are shared by the chitinozoan assemblages observed in the

656 ca. $100 \mathrm{~m}$ thick shale dominated sequence penetrated by the Moussegouda well (northern Chad;

657 Le Hérissé et al., 2013) and in the 4 core samples analysed previously in the KW-2 shallow core

658 (Kufra Basin, Libya; see Grignani et al., 1991; F. Paris in Le Hérissé et al., 2013). The

659 Moussegouda area is geologically regarded as part of the Kufra Basin (see e.g., Lüning et al.,

660 2006) and therefore, the more complete data available on this well can be of some help in

661 interpreting the core from well JA-2 and cuttings from the UN-REMSA well where the

662 overlying and underlying strata are not documented by samples.

663 The analysed samples from well JA-2 and the UN-REMSA well are regarded as post

664 glacial, but are still either of latest Hirnantian age, or at least no younger than earliest

665 Rhuddanian if one follows Loydell's (2007) arguments for the Mauritania material. This

666 uncertainty is indicated by a blue stripe on the graph (Fig. 5) summarising the reassessment of

667 previously reported chitinozoan assemblages from Libya. However, an alternative interpretation,

668 based on an environmental control of the range of the chitinozoans, cannot be definitively ruled

669 out, even if the chitinozoans are not usually deeply affected by environmental factors. Because

670 the moussegoudensis chitinozoan assemblages are so far restricted to the rather nearshore

671 environments of the Kufra Basin (including Chad), the proliferation of E. moussegoudaensis

672 may reflect an environmental control rather than a stratigraphically restricted range. If so, the

673 absence of E. moussegoudaensis in Rhuddanian sections with a graptolite control (deeper 
environments) would simply be a result of differences in the bathymetry of the depositional

675 areas.

Based on the discussion above on chitinozoan biostratigraphy and palaeoecology, it

677 appears that the studied section records an assemblage of latest Ordovician to earliest Silurian

678 age. The acritarchs, miospores and cryptospores assemblage recorded seem to be no older than

679 earliest Rhuddanian. However, several key post-glacial, latest Hirnantian sections, especially the

680 Nseirat section in Mauritania and Anti-Atlas section in Morocco, where post-glacial Hirnantian

681 chitinozoan assemblages have been documented, need to be investigated for acritarch and

682 miospore content, for possible extension of the reported earliest Rhuddanian species to the latest

683 Hirnantian.

684

685 Acknowledgments

686

687 We are very grateful to Faraj Said (National Oil Corporation, Tripoli, Libya), Ahmed I. Asbali

688 (Arabian Gulf Oil Company, Benghazi, Libya), Ramadan Aburawi (Exploration Director, Libya

689 Holdings Co.) and Bourima Belgasem (Libyan Petroleum Institute, Tripoli, Libya) for their

690 scientific support and guidance during the project work in Libya. We also would like to thank

691 the logistics team, provided by Bashir Grenat, for assistance in the field. The administrative and

692 logistical support of staff at the Libyan Petroleum Institute is gratefully acknowledged. Support

693 by the Earth Science Society of Libya is much appreciated. Special thanks go to James Stewart

694 and Clive Johnson for their support during the drilling campaign in the Sahara Desert, to Shir

695 Akbari for palynological sample preparation, and to John E.A. Marshall for providing

696 chitinozoan reflectance data for some of the JA-2 core samples. The consortium of oil and gas

697 industry subscribers is thanked for its financial support to the CASP Southern Basins of Libya 
698 Project. Thijs R.A. Vandenbroucke and an anonoymous reviewer contributed with thoughtful

699 comments to improve the manuscript. This paper is a contribution to the International

700 Geoscience Programme (IGCP) Project 591 - 'The Early to Middle Paleozoic Revolution'.

701

702

Appendix A. Supplementary data

703 Supplementary data associated with this article can be found, in the online version, at xxx.

704

705

\section{References}

Achab, A., 1978. Les chitinozoaires de l'Ordovicien supérieur (Formations de Vauréal et d'Ellis Bay) de l'ïle d'Anticosti, Québec. Palinologia, num. extraord., 1, 1-19.

Al-Ameri, T.K., 1983. Acid resistant microfossils used in the determination of Palaeozoic palaeoenvironment in Libya. Palaeogeography, Palaeoclimatology, Palaeoecology 44, 103

Al-Ameri, T.K., 1989. Chitinozoa of the Tanezzuft and Acacus Formations, Libya. Iraqi Journal 116.

713 Becip, 1974. Regional subsurface biostratigraphy of Ghadamas Basin (Internal Report). National Oil Corporation (Arabian Gulf Oil Co. Benghazi, Libya), Exploration Division Technical

716 Bourahrouh, A., 2002. Chitinozoaires et Palynomorphes de l'Ordovicien supérieur Nordgondwanien; Impact de la Glaciation Ashgilienne. Unpublished Doctoral Thesis, Rennes University, $300 \mathrm{pp}$.

Braddy, S.J., 2001. Eurypterid palaeoecology: palaeobiological, ichnological and comparative evidence for a 'mass-moult-mate' hypothesis. Palaeogeography, Palaeoclimatology, Palaeoecology 172, 115-132. 
Butcher, A., 2009. Early Llandovery chitinozoans from Jordan. Palaeontology 52, 593-629.

723 Butcher, A., 2012. Chitinozoans from the middle Rhuddanian (lower Llandovery, Silurian) 'hot' shale in the E1-NC174 core, Murzuq Basin, SW Libya. Review of Palaeobotany and Palynology, doi:10.1016/j.revpalbo.2012.11.009

Chen, Xu, Rong, J., Mitchell, C.E., Harper, D.A.T., Fan, J.-X., Zhan, R., Zhang, Y., Li, R., from the Yangtze region, South China, with a global correlation. Geological Magazine 137, 623-650.

Chen, Xu, Rong, J., Fan, J.-X., Zhan, R., Mitchell, C.E., Harper, D.A.T., Melchin, M.J., Peng, P., Finney, S.C., Wang, X.-F., 2006. The global boundary stratotype section (GSSP) for the base of the Hirnantian Stage (the uppermost of the Ordovician System). Episodes 29, $183-$ 196.

Da Costa, N.M., 1971. Quitinozoários silurianos do Igarapé da Rainha, Estado do Para. Estado do Pará. Departamento Nacional da Produção Mineral. Divisão de Geologia e Mineralogia Boletim 255, 1-101.

Delabroye, A., Vecoli, M., 2010. The end-Ordovician glaciation and the Hirnantian Stage: global review and questions about Late Ordovician event stratigraphy. Earth-Science Reviews 98, 269-282.

De La Puente, S., 2009. Quitinozoos del Ordovicico de la Cuenca Andina central (noroeste Argentino) y su aplicacion a la bioestratigrafia, paleobiologeigrafia y paleoambientes. Unpublished Thesis, University of Cordoba, 246 pp.

Dorning, J. K., 1981. Silurian acritarch distribution in the Ludlovian shelf sea of South Wales and the Welsh Borderland. In: Neale, J.W., Brasier, M.D. (Eds.), Microfossils from Recent and Fossil Shelf Seas. Ellis Horwood, Chichester, 31-36. 
Dufka, P., Fatka, O., 1993. Chitinozoans and acritarchs from the Ordovician-Silurian boundary of the Prague Basin, Czech Republic. Special Papers in Palaeontology 48, 17-28.

Ghavidel-Syooki, M., 2008. Palynostratigraphy and palaeogeography of the Upper Ordovician Gorgan schists (southeastern Caspian Sea), Eastern Alborz mountain ranges, northern Iran. Comunicações Geológicas 95, 123-155.

Grignani, D., Lanzoni, E., Elatrash, H., 1991. Palaeozoic and Mesozoic subsurface palynostratigraphy in the Al Kufrah Basin, Libya. In: Salem, M. J., Hammuda, O.S., Eliagoubi, B.A. (Eds.), The Geology of Libya, Vol. IV. Elsevier, Amsterdam, 1159-1227. Hill, P.J., Molyneux, S.G., 1988. Biostratigraphy, palynofacies and provincialism of Late Ordovician-Early Silurian acritarchs from northeast Libya. In: El-Arnauti, A. Owens, B., Thusu, B. (Eds.), Subsurface palynostratigraphy of northeast Libya. Garyounis University Publications, Benghazi, 27-43.

Hill, P.J., Paris, F., Richardson, J.B., 1985. Silurian palynomorphs. In: Thusu, B., Owens, B. (Eds.), Palynostratigraphy of North-East Libya. Journal of Micropalaeontology 4, 27-48. International Subcomission on Silurian Stratigraphy, 2007. Final report of the Subcommission on Silurian Stratigraphy restudying the Global Stratotype for the base of the Silurian: A report of the restudy of the defined Global Stratotype of the base of the Silurian System. Silurian Times 14, 10-13.

Jardiné, S., Combaz, A., Magloire, L., Peniguel, G., Vachey, G., 1974. Distribution stratigraphique des Acritarches dans le Paleozoïque du Sahara Algerien. Review of Palaeobotany and Palynology 18, 99-129.

Johnson, N.G., 1985. Early Silurian palynomorphs from the Tuscarora Formation in central Pennsylvania and their paleobotanical and geological significance. Review of Palaeobotany and Palynology 45, 307-360. 
Jones, B., Kjellesvig-Waering, E.N., 1985. Upper Silurian eurypterids from the Leopold Formation, Somerset Island, Arctic Canada. Journal of Paleontology 59, 411-417. Keegan, J.B., Rasul, S.M., Shaheen, Y., 1990. Palynostratigraphy of the Lower Palaeozoic, Cambrian to Silurian, sediment of the Hashemite Kingdom of Jordan. Review of Palaeobotany and Palynology 66, 167-180.

Legrand, P., 2009. Faunal specificity, endemism and paleobiogeography: the post-glacial (Hirnantian-early Rhuddanian) graptolite fauna of the North-African border of Gondwana: a case study. Bulletin de la Société Géologique de France 180, 353-367.

Le Hérissé, A., Al-Tayyar, H., van der Eem, H., 1995. Stratigraphy and paleogeographic significance of Silurian acritarchs from Saudi Arabia. Review of Palaeobotany and Palynology 89, 49-74.

Le Hérissé, A., Massa, D., Paris, F., Steemans, P., 2004. Northern Gondwana palynomorphs from the Ordovician-Silurian boundary beds: The example of northern Chad. Sedimentary basins of Libya, Third Symposium: Geology of East Libya, Benghazi, 21-23 November 2004, Abstract.

Le Hérissé, A., Paris, F., Steemans, P., 2013. Late Ordovician-earliest Silurian palynomorphs from northern Chad and correlation with contemporaneous deposits of southeastern Libya. Bulletin of Geosciences, doi:10.3140/bull.geosci.1383

Loi, A., Ghienne, J.F., Dabard, M.P., Paris, F., Botquelen, A., Christ, N., Elaouad-Debbaj, Z., Gorini, A., Vidal, M., Videt, B., Destombes, J., 2010. The Late Ordovician glacio-eustatic record from a high-latitude storm-dominated shelf succession; the Bou Ingarf section (AntiAtlas, Southern Morocco). Palaeogeography, Palaeoclimatology, Palaeoecology 296, 332358. 
Loydell, D.K., 2007. Graptolites from the Upper Ordovician and Lower Silurian of Jordan.

$$
\text { Special Papers in Palaeontology 78, 1-66. }
$$

Loydell, D.K., 2012. Graptolite biostratigraphy of the E1-NC174 core, Rhuddanian (lower Llandovery, Silurian), Murzuq Basin (Libya). Bulletin of Geosciences 87, 651-660.

Lüning, S., Craig, J., Loydell, D.K., Štorch, P., Fitches, B., 2000. Lower Silurian 'hot shales' in North Africa and Arabia: regional distribution and depositional model. Earth-Science Reviews 49, 121-200.

Lüning, S., Shahin, Y.M., Loydell, D., Al-Rabi, H.T., Masri, A., Tarawneh, B., Kolonic, S., 2005. Anatomy of a world-class source rock: Distribution and depositional model of Silurian organic-rich shales in Jordan and implications for hydrocarbon potential. American Association of Petroleum Geologists Bulletin 89, 1397-1427.

Lüning, S., Loydell, D.K., Štorch, P., Shain, Y., Craig, J., 2006. Origin, sequence stratigraphy, and depositional environment of an Upper Ordovician (Hirnantian) deglacial black shale, Jordan-Discussion. Palaeogeography, Palaeoclimatology, Palaeoecology 230, 352-355.

Melchin, M.J., 2008. Restudy of some Ordovician-Silurian boundary graptolites from Anticosti Island, Canada, and their biostratigraphic significance. Lethaia 41, 155-162.

Melchin, M.J., Williams, S.H., 2000. A restudy of the Akidograptine graptolites from Dob' Linn and a proposed redefined zonation of the Silurian stratotype. In: Cockel P., Wilson, G.A., Brock, G.A., Engelbretsen, M.J., Simpson, A., Winchester-Seeto, T. (Eds.), Palaeontology Down-Under 2000. Geological Society of Australia, Abstracts 61, 63.

Molyneux, S.G., Paris, F., 1985. Late Ordovician palynomorphs. In: Thusu, B., Owens, B. (Eds.), Palynostratigraphy of North-East Libya. Journal of Micropalaeontology 4, 11-26. 
815 Paris, F., 1988. Late Ordovician and Early Silurian chitinozoans from central and southern

816 Cyrenaica. In: El-Arnauti, A., Owens, B., Thusu, B. (Eds.), Subsurface palynostratigraphy 817 of Northeast Libya. Garyounis University Publications, Benghazi, Libya, 61-71.

818 Paris, F., 1990. The Ordovician chitinozoan biozones of the northern Gondwana Domain.

819 Review of Palaeobotany and Palynology 66, 181-209.

820 Paris, F., Bourahrouh, A., Le Hérissé, A., 2000. The effects of the final stages of the Late 821 Ordovician glaciation on marine palynomorphs (chitinozoans, acritarchs, leiospheres) in 822 well N1-2 (NE Algerian Sahara). Review of Palaeobotany Palynology 113, 87-104.

823 Paris, F., Verniers, J., Al-Hajri, S., Al-Tayyar, H., 1995. Biostratigraphy and palaeogeographic 824 affinities of Early Silurian chitinozoans from central Saudi Arabia. Review of Palaeobotany 825 and Palynology 89, 75-90.

826 Paris, F., Deynoux, M., Ghienne, J.F., 1998. Découverte de chitinozoaires à la limite 827 Ordovicien-Silurien en Mauritanie; implications paléogéographiques. Comptes rendus de $828 \quad$ l'Academie des sciences, Series II, 326, 499-504.

829 Paris, F., Thusu, B., Whitham, A., Abutarruma, Y., El Dieb, M., Elkatarry, F.M., Hamhoom, 830 A.M., Howard, J., Lüning, S., Phillips, R., 2008. Late Ordovician-Early Silurian 831 chitinozoan biostratigraphy in Jebel Dalma, Kufra Basin, Libya. Kufra Basin Project, 832 Unpublished CASP Report 9, 43 pp.

833 Paris, F., Thusu, B., Rasul, S., Meinhold, G., Strogen, D., Howard, J.P., Abutarruma, Y., 834 Elgadry, M., Whitham, A.G., 2012. Palynological and palynofacies analysis of early 835 Silurian shales from borehole CDEG-2a in Dor el Gussa, eastern Murzuq Basin, Libya. 836 Review of Palaeobotany and Palynology 174, 1-26. 
Paris, F., Verniers, J., Miller, M., Al-Hajri, S., Melvin, J., Wellman, C.H., 2013. Late Ordovician-earliest Silurian chitinozoans from the Qusaiba core hole (North Central Saudi Arabia) and relation to the Hirnantian glaciation. GeoArabia, Special Publication (in press) Piçarra, J.M., Robardet, M., Bourahrouh, A., Paris, F., Pereira, Z., Le Menn, J., Gourvennec, R., Oliveira, T., Lardeux, H., 2002. Le passage Ordovicien-Silurien et la partie inférieure du Silurien (Sud-Est du Massif Armoricain, France). Comptes Rendus Geosciences 334, 11371183.

Piçarra, J.M., Robardet, M., Oliveira, J.T., Paris, F., Lardeux, H., 2009. Graptolite faunas of the Llandovery "phtanites" at Les Fresnaies (Chalonnes-sur-Loire, southeastern Armorican Massif): Palaeontology and biostratigraphy. Bulletin of Geosciences 84, 41-50.

Richardson, J.B., 1988. Late Ordovician and Early Silurian cryptospores and miospores from northeast Libya. In: El-Arnauti, A., Owens, B., Thusu, B. (Eds.), Subsurface palynostratigraphy of northeast Libya. Garyounis University Publications, Benghazi, Libya, 89-109.

Richardson, J.B., Ioannides, N., 1973. Silurian palynomorphs from the Tanezzuft and Acacus Formations, Tripolitania, North Africa. Micropaleontology 19, 257-307.

Soufiane, A., Achab, A., 2000. Chitinozoan zonation of the Late Ordovician and the Early Silurian of the Island of Anticosti, Québec, Canada. Review of Palaeobotany and Palynology 109, 85-111.

Staplin, F.L., 1969. Sedimentary organic matter, organic metamorphism, and oil and gas occurrences. Bulletin of Canadian Petroleum Geology 17, 47-66.

Štorch, P., 1996. The basal Silurian Akidograptus ascensus-Parakidograptus acuminatus Biozone in peri-Gondwana Europe: graptolite assemblages, stratigraphical ranges and palaeobiogeography. Vestnik Cekeho Geologickeho Ustavu 71, 177-188. 
861 Štorch, P., Loydell, D.K., 1996. The Hirnantian graptolites Normalograptus persculptus and 'Glyptograptus' bohemicus: stratigraphical consequences of their synonymy. Palaeontology 39, 869-881.

864 Taugourdeau, P., 1962. Association de Chitinozoaires dans quelques sondages de la région de 865 Edjelé (Sahara). Revue de Micropaléontologie 4, 229-236.

866 Thusu, B., Syed, R., Whitham, A., Abtarruma, Y., El Dieb, M., Elkatarry, F.M., Hamhoom, 867 A.M., Howard, J., Lüning, S., Phillips, R., 2007. Sub-surface Lower Paleozoic 868 palynostratigraphy in the Kufra Basin, Libya. Kufra Basin Project, Unpublished CASP $869 \quad$ Report 6, 47 pp.

870 Tricker, P.M., Marshall, J.E.A., Badman, T.D., 1992. Chitinozoan reflectance: a Lower 871 Palaeozoic thermal maturity indicator. Marine and Petroleum Geology 9, 302-307. 872 Underwood, C.J., Deynoux, M., Ghienne, J.F., 1998. High palaeolatitude (Hodh, Mauritania) 873 recovery of graptolite faunas after the Hirnantian (end Ordovician) extinction event. Palaeogeography, Palaeoclimatology, Palaeoecology 142, 91-105.

875 Vandenbroucke, T.R.A., 2008. An Upper Ordovician chitinozoan biozonation in British 876 Avalonia (England and Wales). Lethaia 41, 275-294.

877 Vandenbroucke, T.R.A., Rickards, B., Verniers, J., 2005. Upper Ordovician chitinozoan 878 biostratigraphy from the Asghill (Cautley district) and Pus Gill section (Dufton dsistrict, 879 Cross Fell Inlier), Cumbria, Northern England. Geological Magazine 142, 783-807.

880 Vandenbroucke, T.R.A., Gabott, S.E., Paris, F., Aldridge, R.L., Theron, J.N., 2009. Chitinozoans 881 and the age of the Soom Shale, an Ordovician black shale Lagerstätte, South Africa. Journal 882 of Micropalaeontology 28, 53-66. 
883 Verniers, J., Vandenbroucke, T.R.A., 2006. Chitinozoan biostratigraphy in the Dob's Linn 884 Ordovician-Silurian GSSP, Southern Uplands, Scotland. Geologiska Föreningens i $885 \quad$ Stockholm Förhandlingar 128, 195-202.

886 Verniers, J., Nestor, V., Paris, F., Dufka, P., Sutherland, S., Van Grootel, G., 1995. A global 887 Chitinozoa biozonation for the Silurian. Geological Magazine 132, 651-666.

888 Webby, B.D., Cooper, R.A., Bergström, S.M., Paris, F., 2004. Stratigraphic Framework and time 889 slices. In: Webby, B.D., Paris, F., Droser, M., Percival, I. (Eds.), The Great Ordovician 890 Biodiversification Event. Columbia University Press, New York, 41-47.

891 Wellman, C.H., Richardson, J.B., 1993. Terrestrial plant microfossils from Silurian inliers of the $892 \quad$ Midland Valley of Scotland. Palaeontology 36, 155-193.

893 Williams, S.H., Ingham, J.K., 1989. Stratotypes, 4. The Ordovician-Silurian boundary at Dob's 894 Linn, southern Scotland. In: Holland, C.H., Bassett, M.G. (Eds.), A global Standard for the 895 Silurian System. National Museum of Wales, Geological Series 9, 27-35.

896

897 Tables

898

899 Table 1. List of the main palynological and lithological data for the samples processed from well 900 JA-2 and the UN-REMSA well for chitinozoan analysis.

901

902 Table 2. Range and relative frequencies (counted number of species) of the acritarchs recorded 903 in the processed samples from well JA-2 and the UN-REMSA well. 
905 Table 3. Range and relative frequencies (counted number of species) of the sporomorphs and

906 Tortubus portuberans recorded in the processed samples from well JA-2 and the UN-REMSA 907 well.

908

909 Table 4. Kerogen analysis data (grain count of all sizes undertaken under transmitted light) on

910 samples from well JA-2 and on cutting samples (SJS0001) from the UN-REMSA well. Numbers

911 are in percentages.

912

913 Table 5. Chitinozoan reflectance $\left(\mathrm{R}_{\mathrm{ch}}\right)$ values in \% of core samples from well JA-2 (provided by

914 John E. A. Marshall, University of Southampton). The measured reflectance values (average)

915 have been corrected against a standard which was measured at the start and end of every sample

916 series. For every sample the corrected value is close to the average value, showing that there has

917 been not much instrumental drift during reflectance measurements. The vitrinite reflectance $\left(\mathrm{R}_{\mathrm{v}}\right)$

918 values in \% were calculated using the equation in Tricker et al. (1992).

919

920 FIGURE CAPTIONS

921

922 Fig. 1. Map of Libya showing surface outcrops with Paleozoic rocks (dark grey colour) and the 923 location of Jebel Asba at the eastern margin of the Kufra Basin (after Paris et al., 2012). The drill 924 site localities of well CDEG-2a in central Dor el Gussa (Paris et al., 2012) and well JA-2 in 925 southern Jebel Asba (this study) are indicated. The UN-REMSA well was found some $530 \mathrm{~m}$ 926 towards the NNE from JA-2 (not shown in the map). 
928 Fig. 2. Lithological $\log$ of the core from well JA-2 together with biostratigraphic age, 929 chitinozoan abundance and kerogen analysis data (see also Table 4). See text for explanation 930

931 Fig. 3. Selected palynomorph species with stratigraphic ranges and regional occurrences in 932 North Africa, the Middle East and USA (Becip, 1974; Jardiné et al., 1974; Johnson, 1985; 933 Molyneux and Paris, 1985; Hill and Molyneux, 1988; Keegan et al., 1990; Le Hérissé et al., 934 1995; Paris et al., 2012) and comparison with the present study.

936 Fig. 4. Range, relative frequencies and abundances of the chitinozoans recorded in the processed 937 samples from well JA-2.

939 Fig. 5. Correlation table for some Gondwana chitinozoan-bearing strata around the Ordovician-

940 Silurian boundary and their relative stratigraphical position with regard to the range of the main

941 diagnostic chitinozoan species, and to the standard graptolite biozones. 1: F. Paris, unpublished 942 data, 2: Grignani et al., 1991; 3: Paris et al., 2008; 4: Molyneux and Paris, 1985; 5: Paris, 1988;

943 6: Paris et al., 2012; 7: Le Hérissé et al., 2013; 8: Butcher, 2009; 9: Paris et al., 1998; 10 :

944 Vandenbroucke et al., 2009; 11, Bourahrouh, 2002; 12: Piçarra et al., 2002; 13: Dufka and Fatka, 945 1993. Red line: exclusive Late Ordovician species; blue line: exclusive early Silurian taxa; black 946 line: taxa ranging possibly through the Ordovician-Silurian boundary. The blue stripe 947 corresponds to a brief but poorly constrained time slice of uppermost Hirnantian or lowermost 948 Rhuddanian age (i.e. "interregnum" between the top of the persculptus and the base of the 949 ascensus graptolite biozones; see discussion in Legrand, 2009).

950

951 PLATES 
953 Plate I. Scale bar $=10 \mu \mathrm{m}$.

954 1: Rugosphaera tuscarorensis Strother \& Traverse, 1979. Slide no. 5758-3. Core

955 sample at $57.58 \mathrm{~m}$ depth. England finder location: S34-1.

$956 \quad$ 2: $\quad$ Lophozonotriletes sp. Slide no. 5758-3. Core sample at $57.58 \mathrm{~m}$ depth. England

$957 \quad$ finder location: S34-4.

$958 \quad 3: \quad$ Tortotubus protuberans Johnson, 1985. Slide no. 5758. Core sample at $57.58 \mathrm{~m}$

959 depth. England finder location: L28.

960 4: $\quad$ Ambitisporites dilutus (Hoffmeister) Richardson \& Lister, 1969. Slide no. 5553.

$961 \quad$ Core sample at $55.53 \mathrm{~m}$ depth. England finder location: T10.

962 5: Dyadosphaera murusdensa Strother \& Traverse, 1979. Slide no. 5758. Core

$963 \quad$ sample at $57.58 \mathrm{~m}$ depth. England finder location: V37.

964 6: $\quad$ Ambitisporites dilutus (Hoffmeister) Richardson \& Lister, 1969. Slide no. 6759.

965 Core sample at $67.59 \mathrm{~m}$ depth. England finder location: H45-2. Note: The slide

966

$967 \quad 7:$ number corresponds to the core sample depth in $\mathrm{cm}$.

968

969 8:

Ambitisporites dilutus (Hoffmeister) Richardson \& Lister, 1969. Slide no. 6782-5.

970

971

972

973

974

975

976

977

978 Core sample at $67.82 \mathrm{~m}$ depth. England finder location: L31-2.

8: $\quad$ Tetrahedraletes medinensis Strother \& Traverse, 1979, emend. Wellman and Richardson, 1993. Slide no. 6782-5. Core sample at $67.82 \mathrm{~m}$ depth. England finder location: K31-2.

Plate II. Scale bar $=10 \mu \mathrm{m}$.

1: $\quad$ Rugosphaera tuscarorensis Strother \& Traverse, 1979. Slide no. 5758. Core sample at $57.58 \mathrm{~m}$ depth. England finder location: J37-1.

2: $\quad$ Dyadosphaera murusdensa Strother \& Traverse, 1979. Slide no. 5758. Core sample at $57.58 \mathrm{~m}$ depth. England finder location: $\mathrm{f} 41-2$.

979

980

981 4: $\quad$ Veryhachium lairdii group (Deflandre) Deunff, 1954 ex Loeblich, 1970. Slide no.

982

983 5:

984

985 6:

986

$987 \quad 7:$

988

989 8:

990

991

992

993

994

995 2:

996 Tetrahedraletes medinensis Strother \& Traverse, 1979, emend. Wellman \& Richardson, 1993. Slide no. 5758. Core sample at $57.58 \mathrm{~m}$ depth. England finder location: J29-2. 6782-5. Core sample at $67.82 \mathrm{~m}$ depth. England finder location: W28.

: Archaeozonotriletes chulus var. chulus (Cramer) Richardson \& Lister, 1969.

Slide no. 6759. Core sample at $67.59 \mathrm{~m}$ depth. England finder location: J29-3. Dyadosphaera murusdensa Strother \& Traverse, 1979. Slide no. 6782. Core sample at $67.82 \mathrm{~m}$ depth. England finder location: F21-1.

7: $\quad$ Tasmanites sp. Slide no. 4818. Core sample at $48.18 \mathrm{~m}$ depth. England finder location: J41.

8: $\quad$ Veryhachium lairdii group (Deflandre) Deunff, 1954 ex Loeblich, 1970. Slide no. 6782-5. Core sample at $67.82 \mathrm{~m}$ depth. England finder location: X21-1.

Plate III. Scale bar $=10 \mu \mathrm{m}$.

1:
Leiosphaeridia sp. Slide no. 5758-1. Core sample at $57.58 \mathrm{~m}$ depth. England finder location: R44-3.

Rugosphaera sp. Slide no. 5758-2. Core sample at $57.58 \mathrm{~m}$ depth. England finder location: T22. 


\begin{tabular}{|c|c|c|}
\hline $\begin{array}{l}997 \\
998\end{array}$ & 3: & $\begin{array}{l}\text { Leiosphaeridia acerscabrella Johnson, } 1985 . \text { Slide no. } 6782-5 . \text { Core sample at } \\
67.82 \text { m depth. England finder location: T34-2. }\end{array}$ \\
\hline 999 & 4: & Leiosphaerida sp. (in clusters). Slide no. $6782-5$. Core sample at $67.82 \mathrm{~m}$ depth. \\
\hline 1000 & & England finder location: K32 \\
\hline 001 & 5: & $\begin{array}{l}\text { Filisphaeridium sp. Slide no. } 6782-5 \text {. Core sample at } 67.82 \mathrm{~m} \text { depth. England } \\
\text { finder location: H32-4. }\end{array}$ \\
\hline $\begin{array}{l}1003 \\
1004\end{array}$ & 6: & $\begin{array}{l}\text { Solisphaeridium sp. Slide no. } 6759 . \text { Core sample at } 67.59 \mathrm{~m} \text { depth. England } \\
\text { finder location: W23-4. }\end{array}$ \\
\hline $\begin{array}{l}1005 \\
1006\end{array}$ & 7: & $\begin{array}{l}\text { Diexallophasis denticulata (Stockmans \& Williere) Loeblich, 1970. Slide no. } \\
6782 \text {. Core sample at } 67.82 \text { m depth. England finder location: V31-2. }\end{array}$ \\
\hline 1007 & 8: & $\begin{array}{l}\text { Diexallophasis denticulata (Stockmans \& Williere) Loeblich, 1970. Slide no. } \\
\text { 6782-5. Core sample at } 67.82 \text { m depth. England finder location: F18-2. }\end{array}$ \\
\hline
\end{tabular}

1009

1010

1011

Plate IV. Scale bar $=10 \mu \mathrm{m}$.

1: $\quad$ Eupoikilofusa striatifera Cramer, 1970. Slide no. 4818-4. Core sample at $48.18 \mathrm{~m}$

1012

1013

1014

1015

1016

1017

1018

1019

1020

1021

$2:$ depth. England finder location: M19.

Eupoikilofusa striatifera Cramer, 1970. Slide no. 5758-3. Core sample at $57.58 \mathrm{~m}$

3: $\quad$ Leiofusa estrecha Cramer, 1964. Slide no. 6782-5. Core sample at $67.82 \mathrm{~m}$ depth. depth. England finder location: W22.

4: England finder location: H31-4.

4: $\quad$ Moyeria cabottii (Cramer) Miller \& Eames, 1982. Slide no. 6782-5. Core sample

5: at $67.82 \mathrm{~m}$ depth. England finder location: K32-2.

5: $\quad$ Veryhachium trispinosum (Eisenack) Stockmans \& Williere, 1962. Slide no.

$6:$ 4818-4. Core sample at $48.18 \mathrm{~m}$ depth. England finder location: V24

1022

1023

1024 7:

1025

1026

1027

1028

1029

1030

1031

1032

1033

1034 3:

1035

1036

1037

1038

1039

1040 6:

1041

1042 7:

1043 Geron cf. gracilis Cramer, 1969. Note that the tail like feature characteristic in genus Geron is visible in phase contrast only. Slide no. 5758-1. Core sample at $57.58 \mathrm{~m}$ depth. England finder location: D3-2.

7: $\quad$ Veryhachium trispinosum (Eisenack) Stockmans \& Williere, 1962. Slide no. 5758-1. Core sample at $57.58 \mathrm{~m}$ depth. England finder location: W19-2.

8: $\quad$ Veryhachium europaeum Stockmans \& Williere, 1960, 1954 ex Loeblich, 1970. Slide no. 5758-2. Core sample at $57.58 \mathrm{~m}$ depth. England finder location: Q27-3.

Plate V. Scale bar $=10 \mu \mathrm{m}$.

1: $\quad$ Micrhystridium sp. (8 spined form). Slide no. 6721. Core sample at $67.21 \mathrm{~m}$ depth. England finder location: U23.

2. Veryhachium trispinosum (Eisenack) Stockmans \& Williere, 1962. Slide no. 6721. Core sample at $67.21 \mathrm{~m}$ depth. England finder location: M13.

3: Veryhachium trispinosum (Eisenack) Stockmans \& Williere, 1962. Slide no. 6782-5. Core sample at $67.82 \mathrm{~m}$ depth. England finder location: K26-2.

4: $\quad$ Veryhachium europaeum Stockmans \& Williere, 1960. Slide no. 6782-5. Core sample at $67.82 \mathrm{~m}$ depth. England finder location: G28-1.

5: $\quad$ Veryhachium trispinosum (Eisenack) Stockmans \& Williere, 1962. Slide no. 6782-5. Sample at $67.82 \mathrm{~m}$ depth. England finder location: G33-3.

6: Veryhachium sp. (4 spined). Slide no. 6782-5. Core sample at $67.82 \mathrm{~m}$ depth.

England finder location: J24-4.

Micrhystridium sp. (8 spined). Slide no. 6782-5. Core sample at $67.82 \mathrm{~m}$ depth. England finder location: K34-1. 
Plate VI. Scale bar $=100 \mu \mathrm{m}$, except for $1 \mathrm{~b}, 2 \mathrm{~b}, 3 \mathrm{~b}, 4 \mathrm{~b}, 6 \mathrm{~b}, 7 \mathrm{~b}$ and $9 \mathrm{~b}(10 \mu \mathrm{m})$.

1a-b, 2a-b: ?Spinachitina verniersi Vandenbroucke, in Vandenbroucke et al., 2009. Core sample at $55.53 \mathrm{~m}$ depth; IGR 72962. 1a (O49/3): conical specimen with gently tapering flanks and granules/spines concentrated on the margin. $1 \mathrm{~b}$ : close-up of the granules/spines (less than 2 microns length, but possibly eroded) concentrated on the margin. Some granules seem also scattered on the chamber. 2a (N44/4): flattened specimen (vesicle of $150 \mu \mathrm{m}$ length) with a tilted bottom. $2 \mathrm{~b}$ : close-up of the spines (up to $2 \mu \mathrm{m}$ length) erected on the margin (not exactly arranged in a single row).

3a-b: $\quad$ Spinachitina verniersi Vandenbroucke, in Vandenbroucke et al., 2009. Core sample at $55.53 \mathrm{~m}$ depth; IGR 72962 (L47/4). 3a: conical vesicle showing the diagnostic crown of densely distributed spines/granules on the margin. $3 \mathrm{~b}$ : detail of the spines/granules (up to $3 \mu \mathrm{m}$ length) forming a crown around the carina.

4a-b, 8a-b: Euconochitina moussegoudaensis Paris, in Le Hérissé et al., 2013. Core sample at $67.82 \mathrm{~m}$ depth; IGR 72987. 4a (O47/2): conical specimen with gently tapering flanks and a slightly flaring collarette. $4 \mathrm{~b}$ : close-up of the smooth wall surface. $8 \mathrm{a}$ (O47/3): specimen (vesicle of $146 \mu \mathrm{m}$ length) with a partly tilted bottom. 8b: close-up of the margin devoid of spines or granules.

5: $\quad$ Plectochitina cf. longispina (Achab, 1978). Core sample at $67.82 \mathrm{~m}$ depth; 72987 (L38/3).

6a-b: $\quad$ ?Spinachitina verniersi Vandenbroucke, in Vandenbroucke et al., 2009. Core sample at $60.23 \mathrm{~m}$ depth; IGR 729864 (O47). 6a (O47/2): conical specimen with gently tapering flanks. $6 \mathrm{~b}$ : close-up of the margin showing possible granules in row.

7a-b: $\quad$ ?Spinachitina verniersi Vandenbroucke, in Vandenbroucke et al., 2009. Core sample at $67.82 \mathrm{~m}$ depth; IGR 72987 (L43/1). 7a: long conical specimen with a gently flaring collarette and spines concentrated on the margin. $7 \mathrm{~b}$ : close-up showing the spines (up to $3 \mu \mathrm{m}$ length) concentrated on the margin. Some granules (less than $1 \mu \mathrm{m}$ length) seem also scattered on the lower part of the chamber.

9: $\quad$ Plectochitina sp. Core sample at $60.23 \mathrm{~m}$ depth; IGR 72964 (N45/1). Note the long processes branched at their distal part (most of them are broken). The neck is likely damaged.

10: $\quad$ Plectochitina cf. longispina (Achab, 1978). Core sample at $67.82 \mathrm{~m} \mathrm{depth}$; IGR 72987 (M46). Specimen with a long neck ended by a flaring collarette. The processes branch at their about $2 / 3$ of their length.

Plate VII. Scale bar $=100 \mu \mathrm{m}$, except for $1 \mathrm{~b}, 1 \mathrm{c}, 2 \mathrm{~b}, 3 \mathrm{~b}, 4 \mathrm{~b}, 9 \mathrm{~b}$ and $9 \mathrm{c}(10 \mu \mathrm{m})$. $1 \mathrm{a}-\mathrm{c}, 3 \mathrm{a}-\mathrm{b}, 4 \mathrm{a}-\mathrm{b}, 6,8,9 \mathrm{a}-\mathrm{c}$ : Spinachitina oulebsiri Paris et al., 2000. Core sample at $67.59 \mathrm{~m}$ depth; IGR 72981. 1a (M44/1): typical specimen with a well-developed crown of spines (about 20 spines) erected around its margin. 1b: close-up of the spines (up to $8 \mu \mathrm{m}$ length) showing their slender conical shape and their widened hollow base. 1c: detail of the wall surface, which seems rough at high magnification (possibly covered by a bacterial mat). 3a (Q47/1): fairly long specimen (vesicle of 
$170 \mu \mathrm{m}$ length) with a well-developed crown of spines (about 24 spines) around its margin and a conspicuous supra-margin constriction. $3 \mathrm{~b}$ : close-up of the spines (up to $8 \mu \mathrm{m}$ length) erected on the margin showing their slender conical shape and their widened hollow base. 4a (L48): long specimen (vesicle of $190 \mu \mathrm{m}$ length) with a well-developed crown of spines (about 20 spines) around its margin. The supra-margin constriction is weak. $4 \mathrm{~b}$ : close-up of the slender conical spines (up to $11 \mu \mathrm{m}$ length); note the bi-rooted base (possibly resulting of the collapse of the wall of the hollow base). 6 (L48/4): short conical vesicle (vesicle of $130 \mu \mathrm{m}$ length). 8 (O49): very short vesicle (close to $100 \mu \mathrm{m}$ ), note the serrated aperture. 9a (Q49/4): unusual long vesicle (length close to $300 \mu \mathrm{m}$ ) with a conspicuous supra-margin constriction and a fenestrate aperture. $9 \mathrm{~b}$ : close-up of the crown of densely distributed spines (about 30). 9c: close-up of the fenestrate aperture.

2a-b: $\quad$ Spinachitina verniersi Vandenbroucke, in Vandenbroucke et al., 2009. Core sample at $67.59 \mathrm{~m}$ depth; IGR 72981 (Q47). 2a: conical vesicle showing the diagnostic crown of densely distributed granules on the margin. $2 \mathrm{~b}$ : detail of the granules arranged in a crown on the carina.

5: $\quad$ Euconochitina moussegoudaensis Paris, in Le Hérissé et al., 2013. Core sample at 67.59 m depth; IGR 72981 (P47/3).

7. ?Spinachitina verniersi Vandenbroucke, in Vandenbroucke et al., 2009. Core sample at $67.59 \mathrm{~m}$ depth; IGR 72981 (N49/3). Vesicle with granules concentrated on the margin. However, they are not clearly arranged in crown.

Plate VIII. Chitinozoans and one scolecodont from cuttings (no depth provided) from the UNREMSA well, Kufra Basin, Libya; IGR 72995. Scale bar $=100 \mu \mathrm{m}$, except for $3 \mathrm{~b}, 5 \mathrm{~b}, 6 \mathrm{~b}, 8,9 \mathrm{~b}, 10 \mathrm{~b}(10 \mu \mathrm{m})$ and $6 \mathrm{c}(1 \mu \mathrm{m})$.

1: $\quad$ Cyathochitina caputoi Da Costa, 1971. (Q44); note the thick carina and the longitudinal ridges at the junction of the chamber and of the neck.

2: $\quad$ Scolecodont partly "coated" with amorphous organic matter (R45/4).

3a-b, 4, 5a-b: Euconochitina moussegoudaensis Paris, in Le Hérissé et al., 2013. 3a (S46): slightly conical specimen with a well-developed cylindrical neck. $3 \mathrm{~b}$ : close-up of the margin devoid of spines. The granules (about $1 \mu \mathrm{m}$ ) represent likely organic particles stuck on the margin. 4 (U48): gently tapering conical vesicle without any ornamentation on its margin. 5a (S48): slender conical specimen (vesicle of 161 $\mu \mathrm{m}$ length). $5 \mathrm{~b}$ : close-up of the margin showing minute granules (less than one $\mu \mathrm{m})$ concentrated around the base.

$6 \mathrm{a}-\mathrm{c}, 9 \mathrm{a}-\mathrm{b}, 10 \mathrm{a}-\mathrm{b}$ : Spinachitina verniersi Vandenbroucke, in Vandenbroucke et al., 2009. 6 a (P45/2): conical vesicle showing the diagnostic crown of densely distributed granules on the margin. $6 \mathrm{~b}$ : detail of the crown of granules. $6 \mathrm{c}$ : close-up of the granules more or les in row on the margin. 9a (O48/1): long conical vesicle (190 $\mu \mathrm{m}$ length). 9b: detail of the crown of eroded granules. 10a (P49/3): conical vesicle (161 $\mu \mathrm{m}$ length) with densely distributed granules more or less forming a crown on the margin. 10b: detail of the crown of granules on the margin; additional minute granules are randomly scattered on the lower part of the chamber.

7-8: $\quad$ Ancyrochitininae indet. 7 (N44): damaged vesicle (broken processes) coated with amorphous organic matter. 8 (L47/4): antiapertural view of a specimen with broken processes. 
1139 Plate IX. Scale bar $=100 \mu \mathrm{m}$, except for 4, 7, $8(10 \mu \mathrm{m})$ and 3, 5 and $10(1 \mu \mathrm{m})$.

1140 1, 6-8: $\quad$ Tortotubus protuberans Johnson, 1985. 1: Core sample at $60.23 \mathrm{~m}$ depth; IGR

72964 (O43); long branched structure. 6: Core sample at $67.59 \mathrm{~m}$ depth; IGR 72981 (P45/3); fragment of branched structure. 7: Close up of fig. 6 showing bulb-like "vesicles" at the junction between the four branches. 8: Close up showing detail of the bulb-like "vesicles" protruding on the surface of the longest branch of fig. 6.

2-5: $\quad$ Amorphous organic matter (biofilm) after oxidation with $\mathrm{HNO}_{3}$. Core sample at $67.40 \mathrm{~m}$ depth; IGR 72979. 2: Large fragment of organic "sheet". 3: Tilted view of the "sheet" showing the spongy structure of the section. 4: Fragment of "sheet"; see the straight border of a few $\mu \mathrm{m}$ thick. 5: Casts of framboids of pyrite after dissolution with $\mathrm{HNO}_{3}$.

9: $\quad$ Chitinozoan specimen (Ancyrochitininae) adhesively associated with amorphous organic matter (biofilm). Core sample at $67.82 \mathrm{~m}$ depth; IGR 72987 (K43/2).

10: "Sheets" of amorphous organic matter (biofilm). Core sample at $67.82 \mathrm{~m}$ depth, IGR 72987. Detail of the cast of framboids of pyrite when dissolved with $\mathrm{HNO}_{3}$.

Plate X. Scale bar $=100 \mu \mathrm{m}$, except for 13 and $21 \mathrm{~b}(50 \mu \mathrm{m})$.

1: $\quad$ Euconochitina moussegoudaensis Paris, in Le Hérissé et al., 2013. Core sample at 46.60 m depth; IGR 72954 (L48). Short thickset specimen.

2: $\quad$ Euconochitina cf. moussegoudaensis Paris, in Le Hérissé et al., 2013. Core sample at $46.60 \mathrm{~m}$ depth; IGR 72954 (H40). Elongate and slender specimen showing a supra-margin constriction.

3: $\quad$ Euconochitina cf. moussegoudaensis Paris, in Le Hérissé et al., 2013. Core sample at $48.18 \mathrm{~m}$ depth; IGR 72957 (H50/1). Very long specimen.

4: $\quad$ ?Euconochitina moussegoudaensis Paris, in Le Hérissé et al., 2013. Core sample at $50.73 \mathrm{~m}$ depth; IGR 72962 (M46). Teratological specimen with a sleeve gaining the lower vesicle and extending around the succeeding one .

5: $\quad$ Euconochitina moussegoudaensis Paris, in Le Hérissé et al., 2013. Core sample at 50.73 m depth; IGR 72958 (R40/3).

6: $\quad$ Euconochitina moussegoudaensis Paris, in Le Hérissé et al., 2013. Core sample at 55.07 m depth; IGR 72959 (S36).

7: $\quad$ Euconochitina moussegoudaensis Paris, in Le Hérissé et al., 2013. Core sample at 60.23 m depth; IGR 72965 (M39/1). Short specimen.

8, 10: Euconochitina moussegoudaensis Paris, in Le Hérissé et al., 2013. Core sample at 64.02 m depth; IGR 72967. 8 (G32/4). 10: short specimen (G41/2).

9: $\quad$ Euconochitina cf. moussegoudaensis Paris, in Le Hérissé et al., 2013. Core sample at $64.02 \mathrm{~m}$ depth; IGR 72967 (G38/4). Elongate and slender specimen with a supra-margin constriction.

11: Euconochitina cf. moussegoudaensis Paris, in Le Hérissé et al., 2013. Core sample at $65.74 \mathrm{~m}$ depth; IGR 72968 (O42). Elongate and slender specimen with a supra-margin constriction.

12: $\quad$ Euconochitina moussegoudaensis Paris, in Le Hérissé et al., 2013. Core sample at 65.74 m depth; IGR 72968 (P43/3). Short and thickset specimen.

13: $\quad$ Calpichitina sp. Core sample at $66.85 \mathrm{~m}$ depth; IGR 72970 (J50/2). 
1184 14-16: $\quad$ Euconochitina moussegoudaensis Paris, in Le Hérissé et al., 2013. Core sample at

1185

1186 17:

1187 18:

1188

1189

1190

1191

1192

1193

1194

1195

1196

1197

1198

1199

1200

1201

1202

1203

1204

1205

1206

1207

1208

1209

1210

1211

1212

1213

1214

1215

1216

1217

1218

1219

1220

1221

1222

1223

1224

1225

1226

1227

1228

1229

1230

66.85 m depth. 14: (N39); 15: (L45); 16 (T34/4).

Ancyrochitinidae indet. Core sample at $67.05 \mathrm{~m}$ depth (H44).

Euconochitina moussegoudaensis Paris, in Le Hérissé et al., 2013. Core sample at $67.05 \mathrm{~m}$ depth. Short and thickset specimen (Q41/1).

19-20: $\quad$ Euconochitina cf. moussegoudaensis Paris, in Le Hérissé et al., 2013. Core sample at $67.05 \mathrm{~m}$ depth; IGR 72974. Elongate and slender specimens with a weakly expressed supra-margin constriction. 19 (Q42); 20 (K49/1).

21a-b: $\quad$ Spinachitina cf. S. oulebsiri Paris et al., 2000. Core sample at $62.34 \mathrm{~m}$ depth; IGR 72966 (F.35/4); 21b: close-up showing the spines on the margin.

Plate XI. Scale bar $=100 \mu \mathrm{m}$.

1: $\quad$ Spinachitina oulebsiri Paris et al., 2000. Core sample at $67.21 \mathrm{~m}$ depth; IGR 72975 (F37/4).

2: $\quad$ Spinachitina cf. verniersi Vandenbroucke, in Vandenbroucke et al., 2009. Core sample at $67.21 \mathrm{~m}$ depth; IGR 72975 (M45). Specimen showing a conspicuous supra-margin constriction.

3: $\quad$ Euconochitina cf. moussegoudaensis Paris, in Le Hérissé et al., 2013. Core sample at $67.21 \mathrm{~m}$ depth; IGR 72975 (N47/2).

4: $\quad$ Spinachitina cf. verniersi Vandenbroucke, in Vandenbroucke et al., 2009. Core sample at $67.40 \mathrm{~m}$ depth; IGR 72976 (M38/2). Short specimen.

5: $\quad$ Euconochitina cf. moussegoudaensis Paris, in Le Hérissé et al., 2013. Core sample at $67.40 \mathrm{~m}$ depth; IGR 72976 (035).

6: $\quad$ Spinachitina oulebsiri Paris et al., 2000. Core sample at $67.59 \mathrm{~m}$ depth;72982 (L52). Abnormally short specimen.

7-10: $\quad$ Spinachitina oulebsiri Paris et al., 2000. Core sample at $67.59 \mathrm{~m}$ depth; 72982.7 : short specimen (M45). 8: (O36). 9: slender specimen (V49). 10: (O47)

11: Euconochitina cf. moussegoudaensis Paris, in Le Hérissé et al., 2013. Core sample at $67.82 \mathrm{~m}$ depth; 72982 (K44/2). Elongate and slender specimen with a supra-margin constriction and a uncommon well-developed neck.

12: $\quad$ Euconochitina sp. aff. vitrea (Taugourdeau, 1962). Core sample at $67.82 \mathrm{~m}$ depth; IGR 72985 (K40/1).

13-15, 17: Plectochitina cf. longispina (Achab, 1978). Core sample at $67.82 \mathrm{~m}$ depth; IGR 72985. 13: well-developed neck and broken processes (L48/4). 14: long branched processes (R34/3). 15: note the spongy processes (K46/1). 17: specimen with well-branched processes stuck on a biofilm (S37/4).

16: Euconochitina moussegoudaensis Paris, in Le Hérissé et al., 2013. Core sample at 67.97 m depth; IGR 72988 (O44/3).

18-20: $\quad$ Euconochitina moussegoudaensis Paris, in Le Hérissé et al., 2013. Cuttings from UN-REMSA well; IGR 72955 18: (L43/2); 19: (O37/3); 20: (P39/4).

21: Cyathochitina caputoi Da Costa, 1971. Cuttings from UN-REMSA well; IGR 72995 (K38).

Plate XII. Scale bar $=100 \mu \mathrm{m}$, except for $7,8,10-13$ and $19(50 \mu \mathrm{m})$.

1-2, 17: $\quad$ Scolecodont indet. 1: Core sample at $46.60 \mathrm{~m}$ depth; IGR 72954 (O43/3). 2: Core sample at $48.18 \mathrm{~m}$ depth; IGR 72957 (U42). 17: Core sample at $67.21 \mathrm{~m}$ depth; IGR 729575 (M39/3). 
1231 3-6: $\quad$ Eurypterid remains. Core sample at $50.73 \mathrm{~m}$ depth; IGR 72958. 3: fragment of

1232

1233

1234

1235

1236

1237

1238

1239

1240

1241

1242

1243

1244

1245

1246

1247

1248

1249 cuticle (M41/1). 4: fragment of cuticle of a ventral segment (P44/1). 5: "sensorial hair" (P34/1). 6: claw? (M41/1).

7: $\quad$ Ornamented palynomorph recalling Tasmanites tzadiensis La Hérissé, in Le Hérissé et al., 2013. Core sample at $50.73 \mathrm{~m}$ depth; IGR 72958 (S34).

8, 11-13: Tasmanites tzadiensis Le Hérissé, in Le Hérissé et al., 2013. 7: Core sample at $50.73 \mathrm{~m}$ depth (S34). 8: Core sample at $50.73 \mathrm{~m}$ depth (Q42/3). 11: Core sample at $60.23 \mathrm{~m}$ depth (J28/1). 12: Core sample at $62.34 \mathrm{~m}$ depth (M39). 13: Core sample at $66.85 \mathrm{~m}$ depth (L47/1).

9, 14, 18: Tortotubus protuberans Johnson, 1985. 9: Core sample at $57.58 \mathrm{~m}$ depth; IGR 72963 (M51); branched structure. 14: Core sample at $66.85 \mathrm{~m}$ depth; IGR 72970 (U48/1); fragment. 18: Core sample at $67.21 \mathrm{~m}$ depth; IGR 72975 (S43); branched element.

10: $\quad$ Connected palynomorphs. Core sample at $57.58 \mathrm{~m}$ depth; IGR 72963 (N47/4).

15-16: "Sheets or blades" of amorphous organic matter (biofilm). Core sample at 66.85 $\mathrm{m}$ depth. 15: framboids of pyrite removed (circular depressions) after oxidation with $\mathrm{HNO}_{3}$. IGR 72973 (N39/2). 16: biofilm without oxidation by $\mathrm{HNO}_{3}$ showing black microspheres representing framboids of pyrite; IGR $72972(\mathrm{P} 45 / 1)$.

19: $\quad$ Colony of cyanobacteria. Core sample at $67.97 \mathrm{~m}$ depth; IGR 72988 (R50/2). 


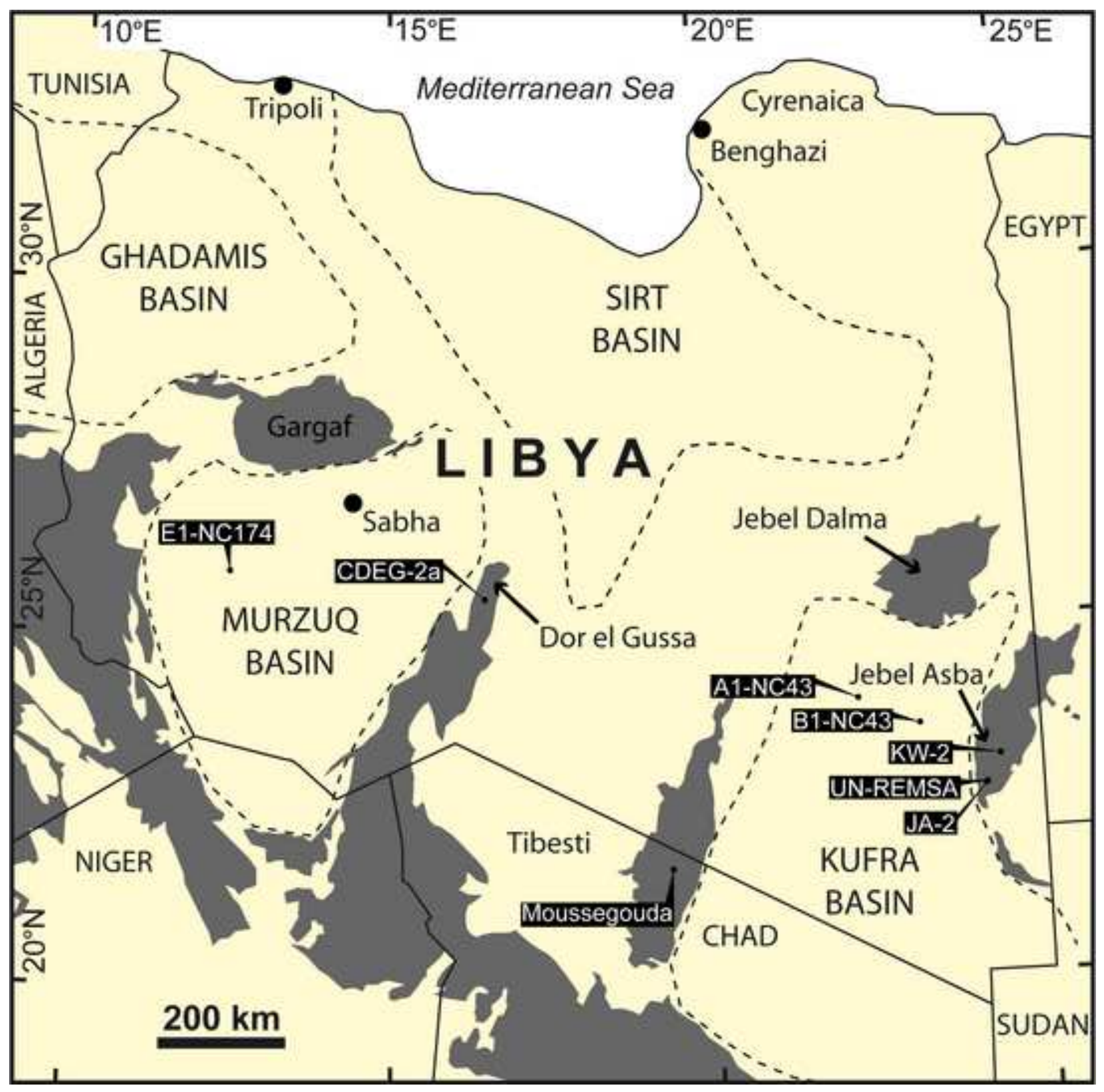




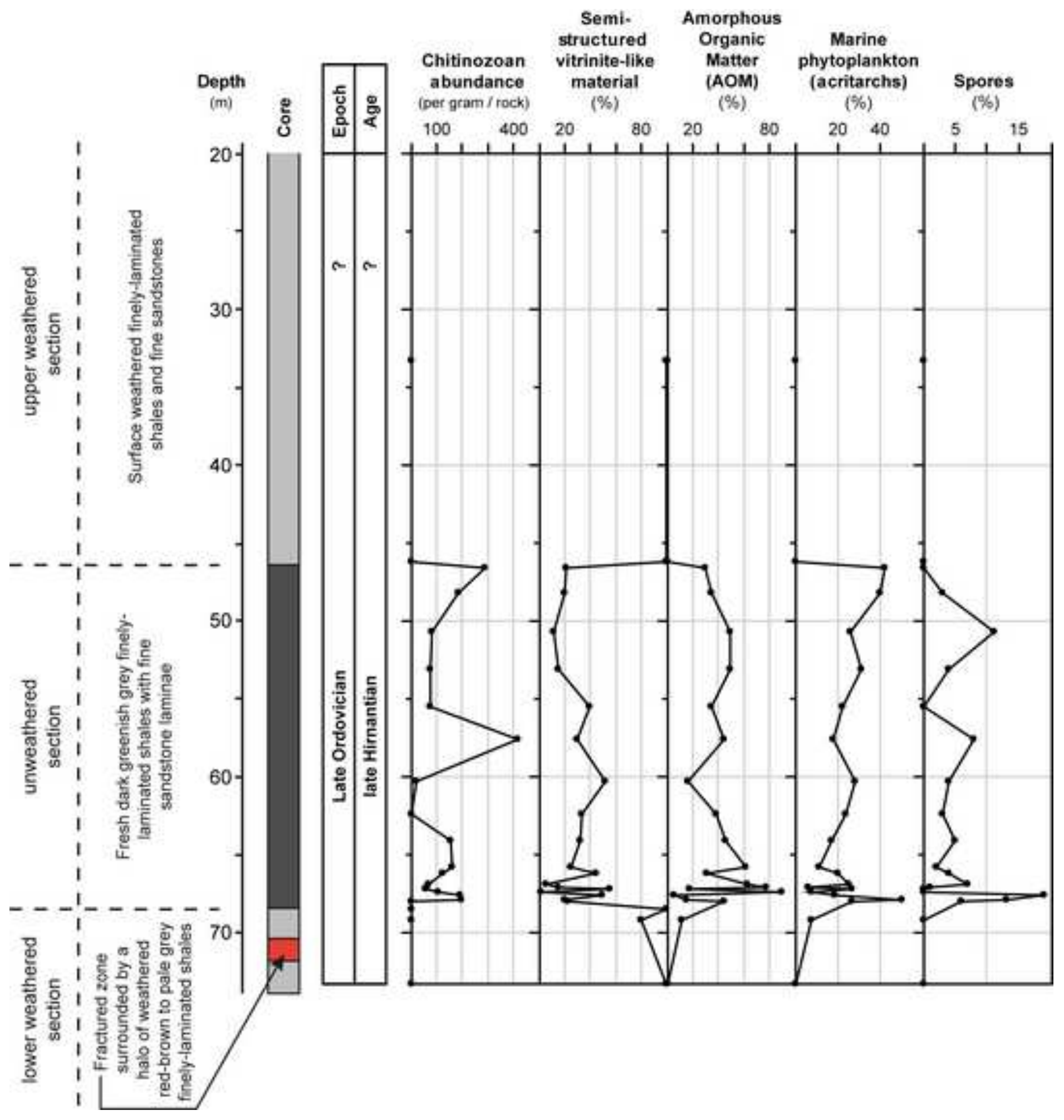




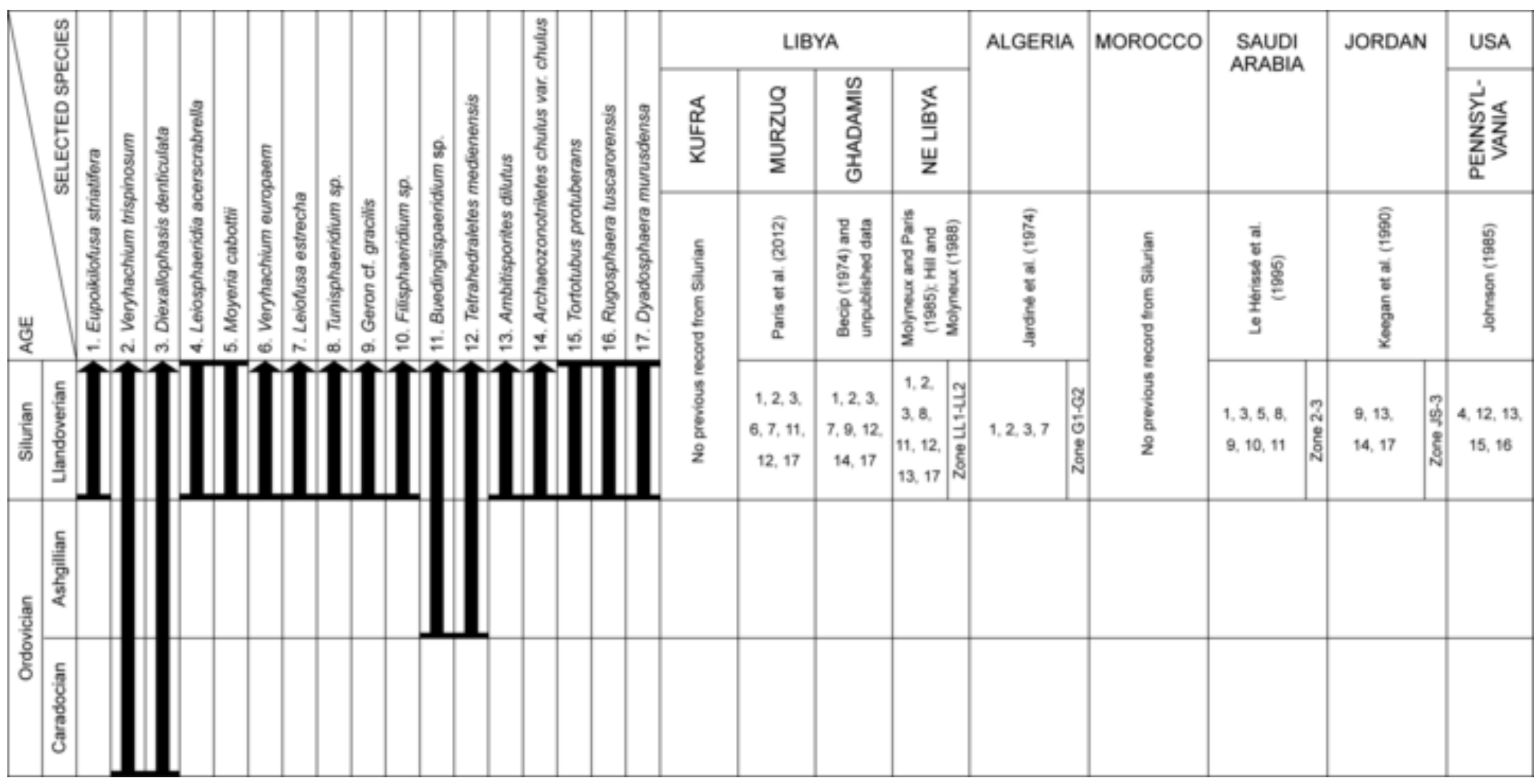




\begin{tabular}{|c|c|c|c|c|c|c|c|c|c|c|c|c|c|c|}
\hline 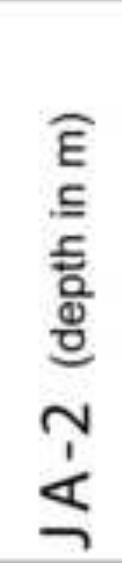 & 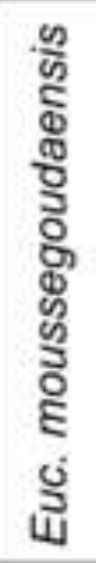 & 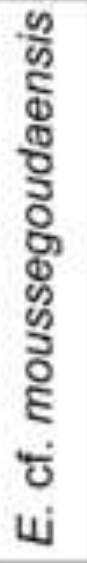 & 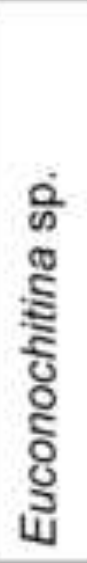 & 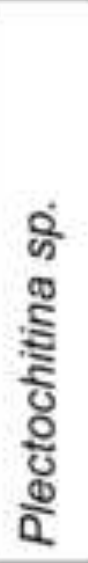 & 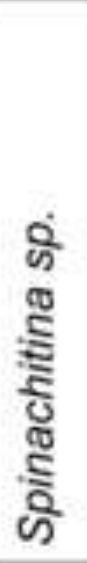 & 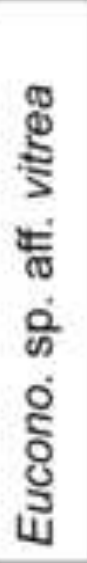 & 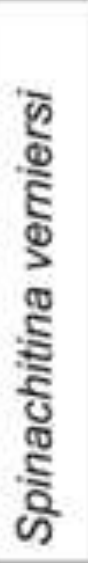 & 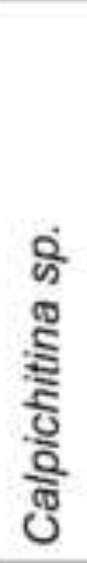 & 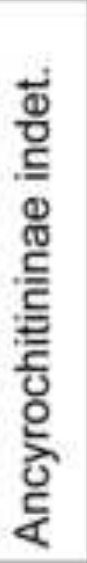 & 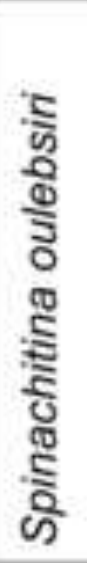 & 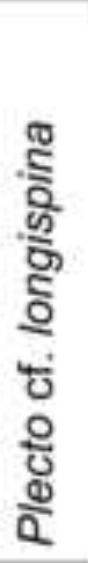 & 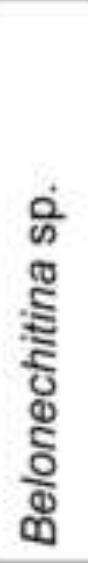 & 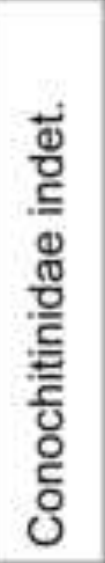 & 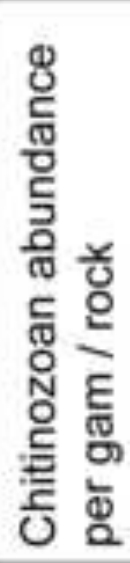 \\
\hline 33.33 & 100 & & & & & & & & & & & & & $<1$ \\
\hline 46.20 & 100 & & & & & & & & & & & & & $<1$ \\
\hline 46.60 & 98 & $<1$ & $<1$ & & & & & & & & & & & 292 \\
\hline 48.18 & 98 & $<1$ & $<1$ & $<1$ & & & & & & & & & & 189 \\
\hline 50.73 & 98 & & 2 & & & & & & & & & & & 82 \\
\hline 53.07 & 99 & & $<1$ & & & & & & & & & & & 74 \\
\hline 55.53 & 99 & & & & & & $<1$ & & & & & & & 75 \\
\hline 57.58 & 98 & $<1$ & $<1$ & & & & & & & & & & & 415 \\
\hline 60.23 & 98 & & & & & & $?$ & & & & $<1$ & & & 23 \\
\hline 62.34 & 96 & & & & 3 & & & & & cf. & & & & 5 \\
\hline 64.02 & 95 & 1 & 4 & & & & & & & & & & & 128 \\
\hline 65.74 & 96 & 2 & & & & $<1$ & $<1$ & & & & & & & 160 \\
\hline 66.21 & 99 & & $<1$ & & & & & & & & & & & 157 \\
\hline 66.85 & 98 & & $<1$ & & & & & $<1$ & & & & & & 72 \\
\hline 67.05 & 96 & 2 & & & & & & & $<1$ & cf. & & & & 61 \\
\hline 67.21 & 96 & $<1$ & & & & & cf. & & 1 & 2 & & & & 59 \\
\hline 67.40 & 96 & & & & & & 2 & & & 2 & & & & 109 \\
\hline 67.59 & 44 & $<1$ & & & & & 20 & & $<1$ & 35 & & & & 190 \\
\hline 67.82 & 26 & $<1$ & & $<1$ & & $<1$ & $?$ & & & & 70 & $<1$ & & 197 \\
\hline 67.97 & 85 & & & 15 & & & & & & & & & & 3 \\
\hline 68.42 & & & & & & & & & & & & & & 1 \\
\hline 69.12 & 100 & & & & & & & & & & & & & $<1$ \\
\hline 73.21 & & & & & & & & & & & & & 100 & $<1$ \\
\hline
\end{tabular}




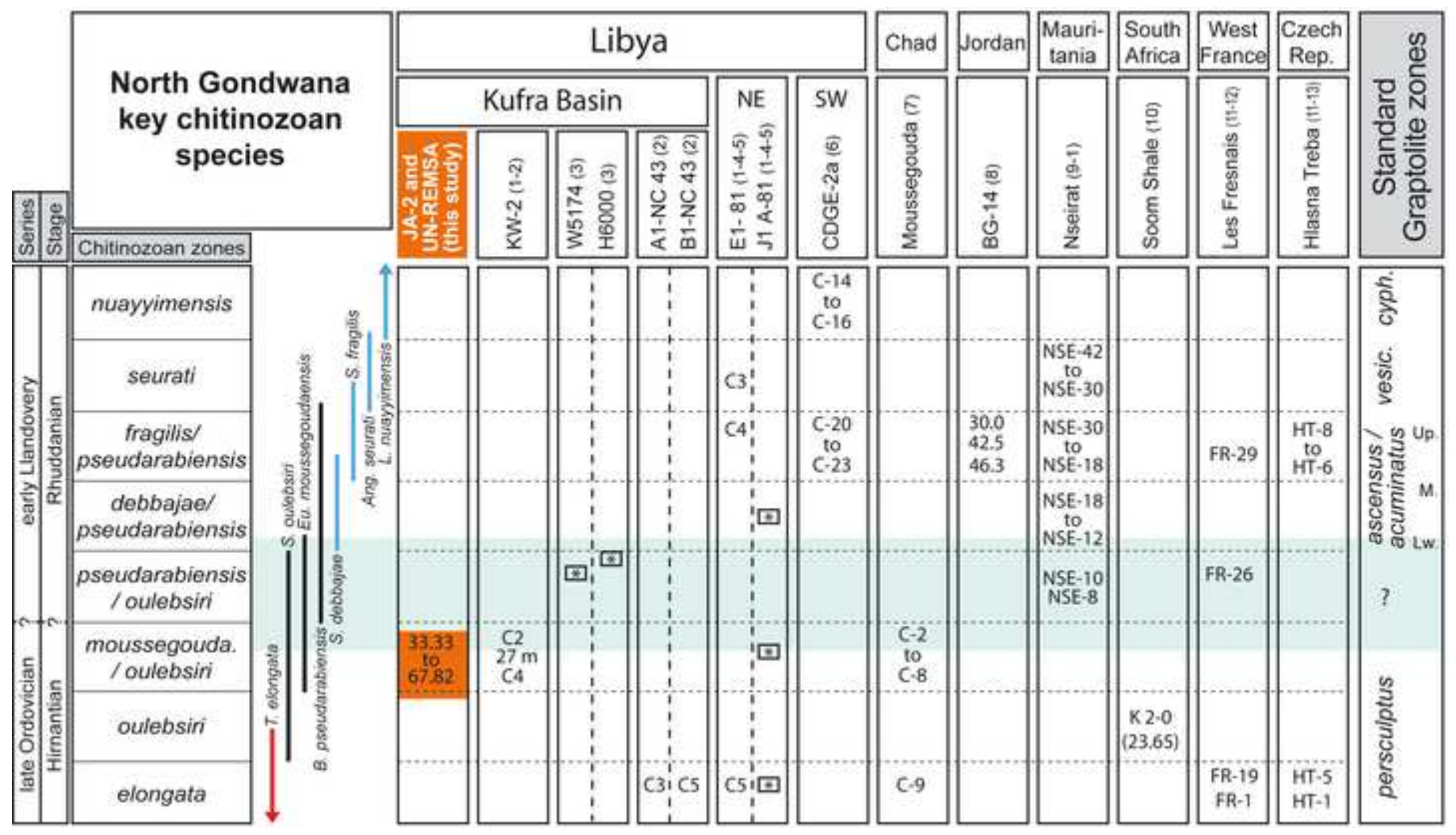


Table 1.

\begin{tabular}{|c|c|c|c|c|c|c|c|c|c|c|c|}
\hline 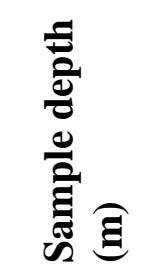 & 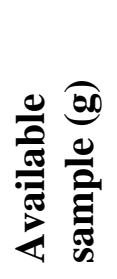 & 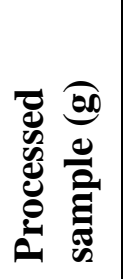 & 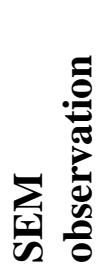 & 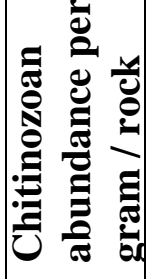 & 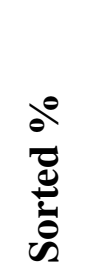 & 昜 & $\frac{\mathscr{n}}{\stackrel{0}{0}}$ & 绨 & 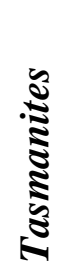 & & 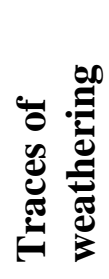 \\
\hline \multicolumn{12}{|l|}{ JA-2 } \\
\hline 33.33 & 10.4 & 4.0 & & $<1$ & 100 & $\mathrm{X}$ & & & & beige silty shale & $\mathrm{XX}$ \\
\hline 46.20 & 10.9 & 5.6 & & $<1$ & 100 & $\mathrm{X}$ & $\mathrm{X}$ & & & beige silty shale & $\mathrm{X}$ \\
\hline 46.60 & 10.2 & 5.0 & YES & 292 & 10 & $\mathrm{X}$ & $\mathrm{X}$ & & $\mathrm{X}$ & grey silty shale & \\
\hline 48.18 & 11.3 & 5.6 & & 189 & 62 & & $\mathrm{X}$ & & & grey silty shale & \\
\hline 50.73 & 9.3 & 4.3 & & 82 & 90 & & $\mathrm{X}$ & $\mathrm{X}$ & $\mathrm{X}$ & grey silty shale & \\
\hline 53.07 & 6.7 & 4.0 & & 74 & 50 & $\mathrm{XX}$ & & & & grey silty shale & \\
\hline 55.53 & 14.3 & 6.0 & YES & 75 & 100 & & & & & grey shale & \\
\hline 57.58 & 11.6 & 5.1 & & 415 & 10 & & & & & grey siltst., micas & \\
\hline 60.23 & 7.1 & 5.1 & YES & 23 & 100 & & & $X$ & $\mathrm{X}$ & grey siltst., micas & \\
\hline 62.34 & 8.5 & 5.1 & & 5 & 100 & & & $\mathrm{X}$ & $\mathrm{X}$ & grey siltst., micas & \\
\hline 64.02 & 11.3 & 7.0 & & 154 & 10 & $\mathrm{X}$ & & $\mathrm{X}$ & & grey siltstone & \\
\hline 65.74 & 7.7 & 5.0 & & 160 & 10 & $\mathrm{X}$ & & & & grey shale & \\
\hline 66.21 & 14.5 & 7.0 & & 128 & 10 & $\mathrm{XX}$ & & & & grey shale & \\
\hline 66.85 & 10.0 & 5.1 & & 72 & 20 & $\mathrm{XX}$ & & & $\mathrm{X}$ & grey shale & \\
\hline 67.05 & 5.0 & 3.5 & & 61 & 80 & $\mathrm{XX}$ & & & & greenish shale & \\
\hline 67.21 & 5.6 & 3.7 & & 59 & 90 & $\mathrm{XX}$ & $X$ & & & greenish shale & \\
\hline 67.40 & 4.6 & 3.3 & YES & 109 & 80 & $\mathrm{XX}$ & & & & greenish shale & \\
\hline 67.59 & 8.0 & 5.0 & YES & 190 & 10 & $\mathrm{X}$ & & & & grey shale & \\
\hline 67.82 & 4.4 & 3.2 & YES & 197 & 50 & $\mathrm{XX}$ & & & & fine beige sand. & \\
\hline 67.97 & 3.8 & 2.4 & & 3 & 100 & & & & $\mathrm{X}$ & fine beige sand. & $\mathrm{X}$ \\
\hline 68.42 & 5.2 & 3.2 & & I & 100 & & & & & fine beige sand. & $X$ \\
\hline 69.12 & 8.6 & 5.2 & & $<1$ & 100 & $X$ & & & & whitish & $\mathrm{XX}$ \\
\hline 73.21 & 11.3 & 5.0 & & $<1$ & 100 & $\mathrm{X}$ & & & & grey shale & \\
\hline \multicolumn{12}{|l|}{$\begin{array}{c}\text { UN- } \\
\text { REMSA }\end{array}$} \\
\hline SJS0001 & & 4.0 & YES & 125 & 10 & $\mathrm{X}$ & $\mathrm{X}$ & & & dark silty shale & \\
\hline
\end{tabular}

Explanation: X (present), XX (abundant) 
Table 2.

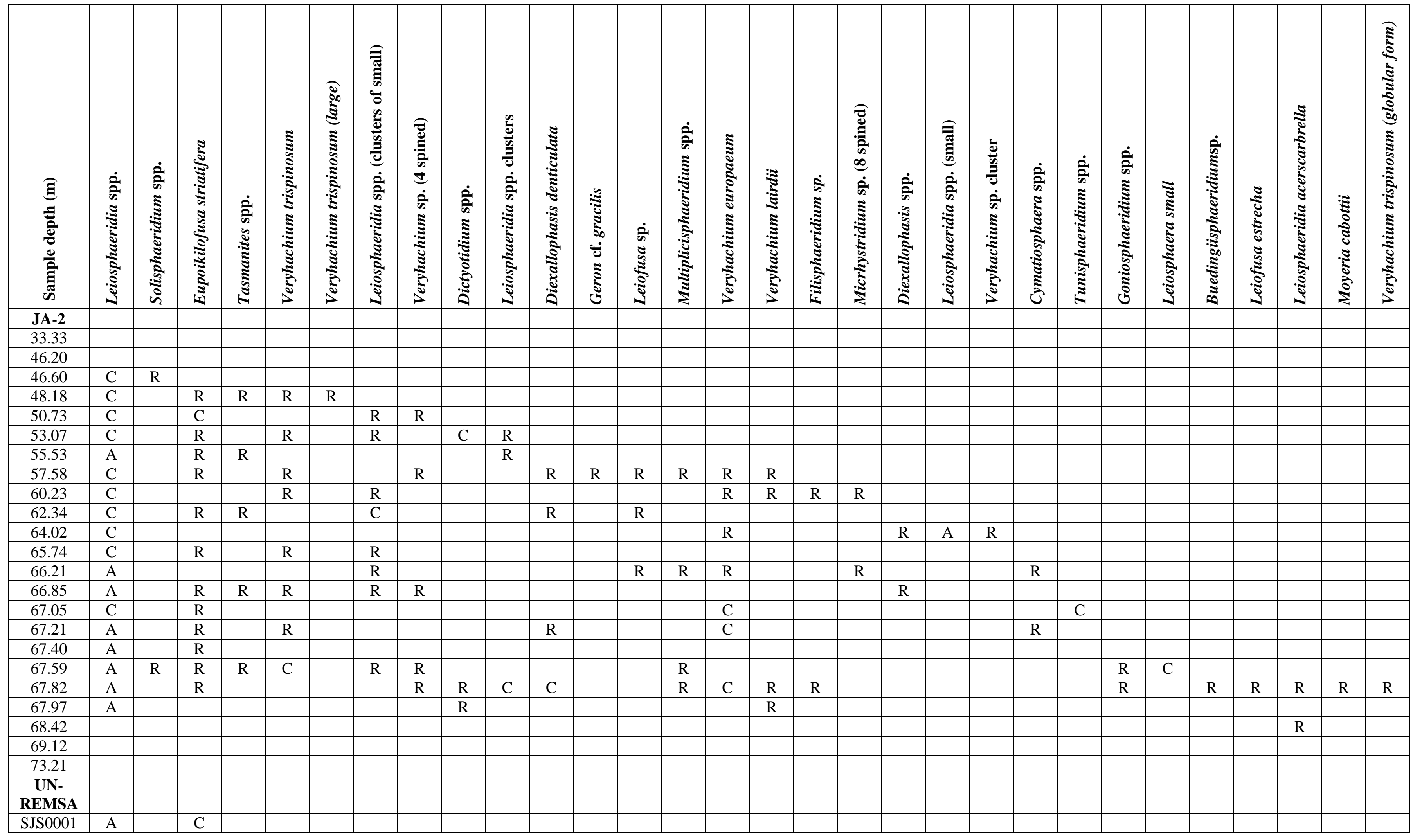

Explanation: R: Rare (1-5), C: Common (6-19), A: Abundant (20+) 
Table 3.

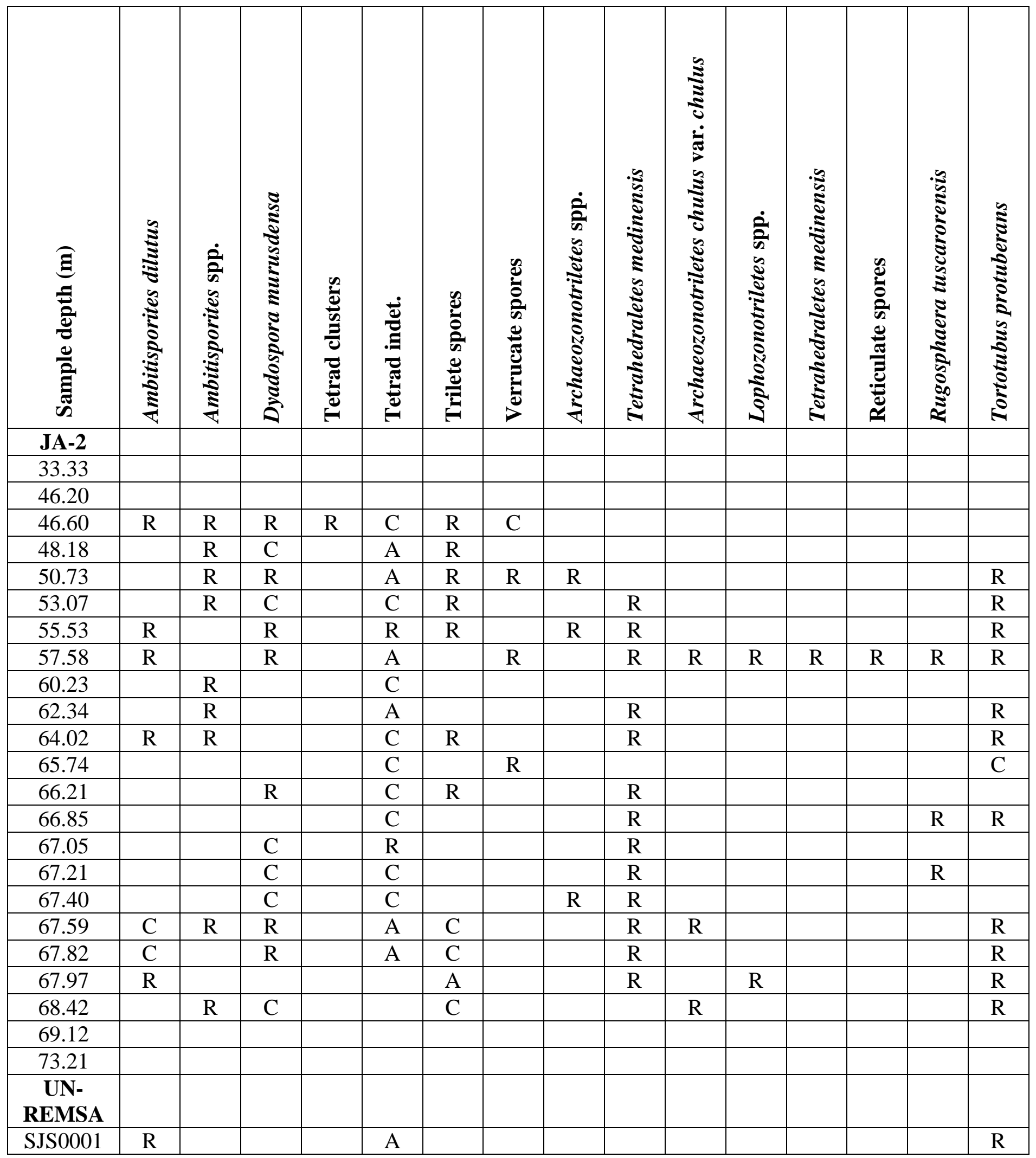

Explanation: R: Rare (1-5), C: Common (6-19), A: Abundant (20+) 
Table 4.

\begin{tabular}{|c|c|c|c|c|c|c|c|c|c|c|}
\hline 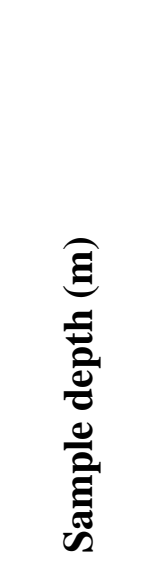 & 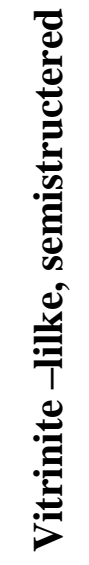 & 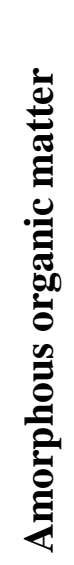 & שٍ & 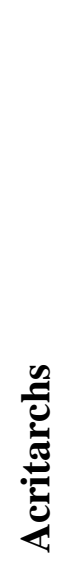 & : & 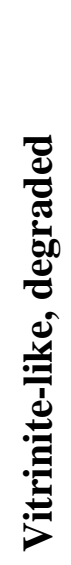 & 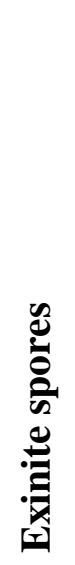 & 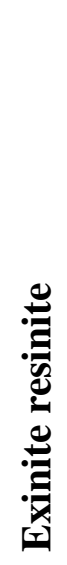 & 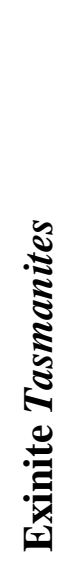 & 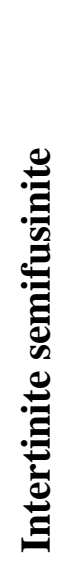 \\
\hline \multicolumn{11}{|l|}{ JA-2 } \\
\hline 33.33 & 100 & & & & & & & & & \\
\hline 46.20 & 100 & & & & & & & & & \\
\hline 46.60 & 21 & 30 & 1 & 42 & 1 & 4 & & & & \\
\hline 48.18 & 20 & 35 & & 40 & 1 & 1 & 3 & & & \\
\hline 50.73 & 12 & 50 & & 26 & 1 & & 11 & & & \\
\hline 53.07 & 15 & 50 & & 31 & & & 4 & & & \\
\hline 55.53 & 40 & 35 & & 22 & & & & 3 & & \\
\hline 57.58 & 30 & 44 & & 18 & & & 8 & & & \\
\hline 60.23 & 52 & 16 & & 28 & & & 4 & & & \\
\hline 62.34 & 34 & 38 & & 24 & & & 3 & & & \\
\hline 64.02 & 32 & 46 & & 17 & & & 5 & & & \\
\hline 65.74 & 25 & 61 & & 11 & 1 & & 2 & & & \\
\hline 66.21 & 45 & 31 & & 20 & & & 4 & & & \\
\hline 66.85 & 5 & 63 & & 25 & & & 7 & & & \\
\hline 67.05 & 15 & 78 & & 6 & & & 1 & & & \\
\hline 67.21 & 55 & 18 & & 27 & & & & & & \\
\hline 67.40 & 2 & 90 & & 8 & & & & & & \\
\hline 67.59 & 50 & 6 & & 19 & 6 & & 19 & & & \\
\hline 67.82 & 20 & 15 & & 50 & & 1 & 13 & & 1 & \\
\hline 67.97 & 22 & 45 & & 27 & & & 6 & & & \\
\hline 68.42 & 100 & & & & & & & & & \\
\hline 69.12 & 80 & 11 & & 8 & & & & & & 1 \\
\hline 73.21 & 100 & & & & & & & & & \\
\hline \multicolumn{11}{|l|}{$\begin{array}{c}\text { UN- } \\
\text { REMSA }\end{array}$} \\
\hline SJS0001 & 5 & 89 & & 2 & & 2 & 2 & & & \\
\hline
\end{tabular}


Table 5.

\begin{tabular}{cccccccc}
\hline $\begin{array}{c}\text { Sample } \\
\text { depth }(\mathbf{m})\end{array}$ & $\begin{array}{c}\mathbf{R}_{\text {ch }} \\
\text { average }\end{array}$ & $\begin{array}{c}\text { Corrected } \\
\text { average }\end{array}$ & Count & $\begin{array}{c}\text { Standard } \\
\text { deviation }\end{array}$ & Minimum & Maximum & $\begin{array}{c}\mathbf{R}_{\mathbf{v}} \\
\text { calculated }\end{array}$ \\
\hline 46.60 & 0.59 & 0.57 & 49 & 0.029 & 0.54 & 0.65 & 0.44 \\
46.60 & 0.56 & 0.55 & 66 & 0.036 & 0.48 & 0.63 & 0.41 \\
48.18 & 0.60 & 0.58 & 4 & 0.021 & 0.58 & 0.62 & 0.45 \\
57.58 & 0.55 & 0.56 & 72 & 0.043 & 0.47 & 0.63 & 0.41 \\
64.02 & 0.63 & 0.63 & 20 & 0.031 & 0.58 & 0.68 & 0.48 \\
64.02 & 0.63 & 0.61 & 22 & 0.065 & 0.55 & 0.74 & 0.48 \\
65.74 & 0.50 & 0.49 & 74 & 0.031 & 0.45 & 0.55 & 0.36 \\
65.74 & 0.54 & 0.53 & 22 & 0.019 & 0.52 & 0.57 & 0.40 \\
67.82 & 0.52 & 0.51 & 5 & 0.026 & 0.49 & 0.55 & 0.38 \\
\hline
\end{tabular}



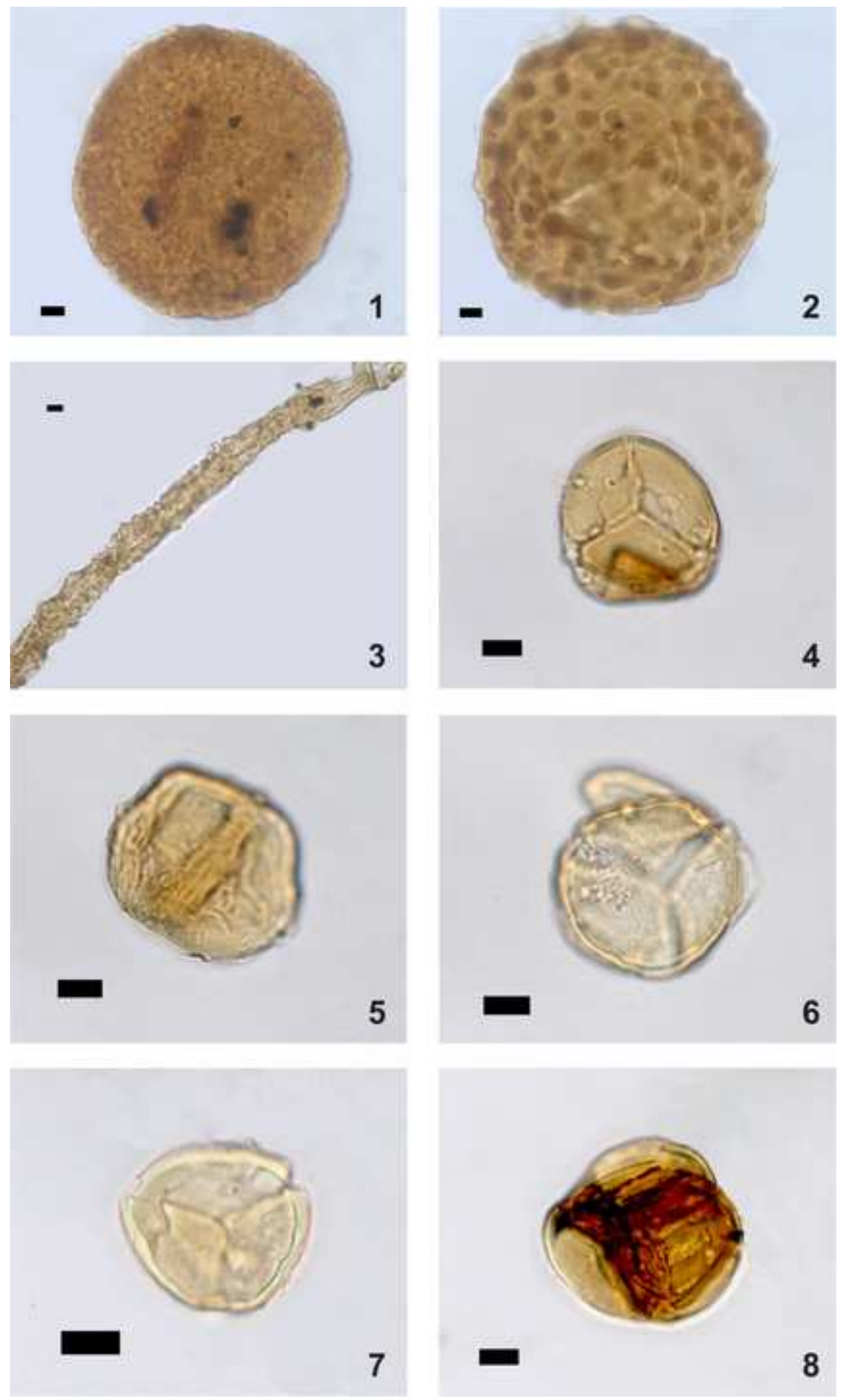

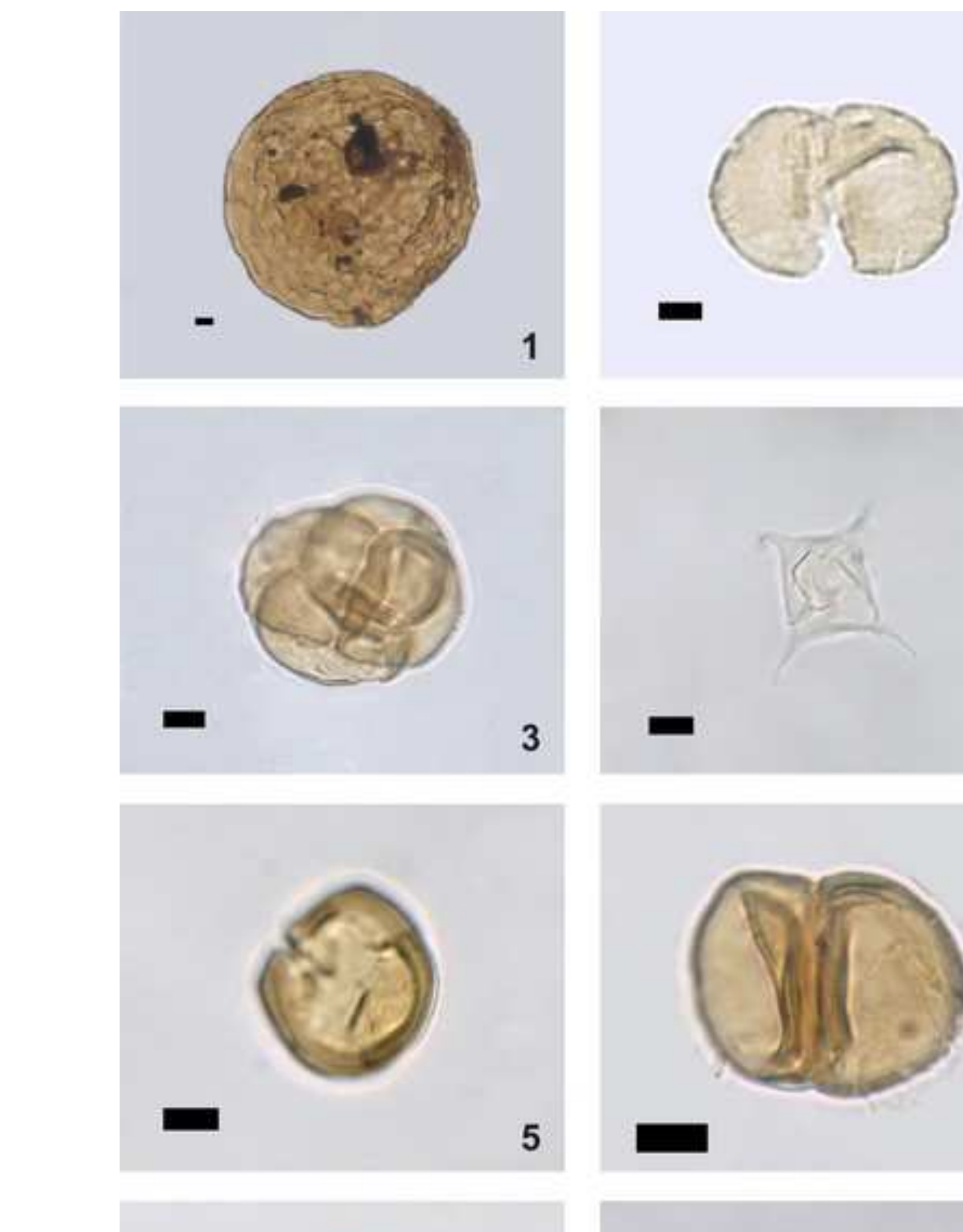

2

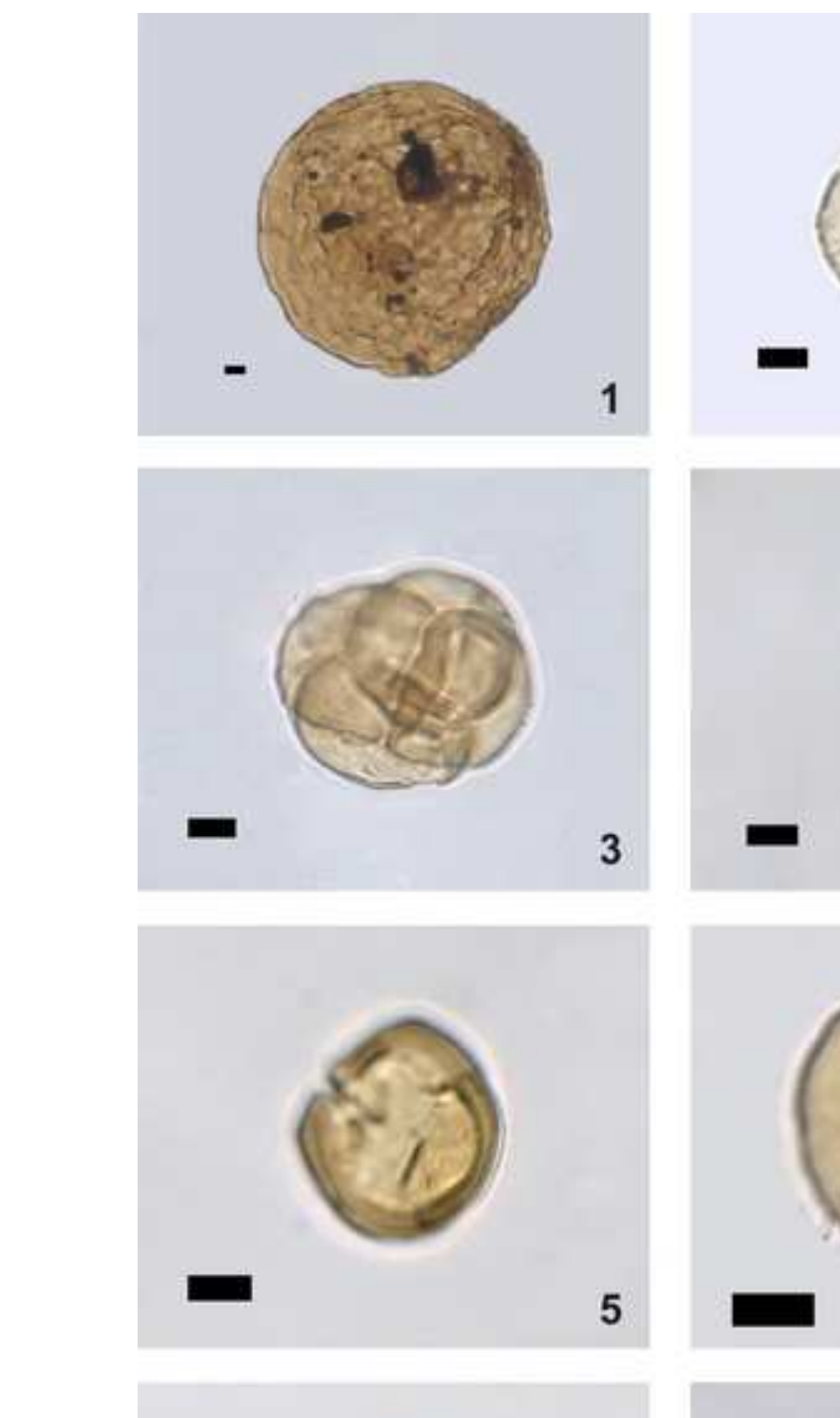

3
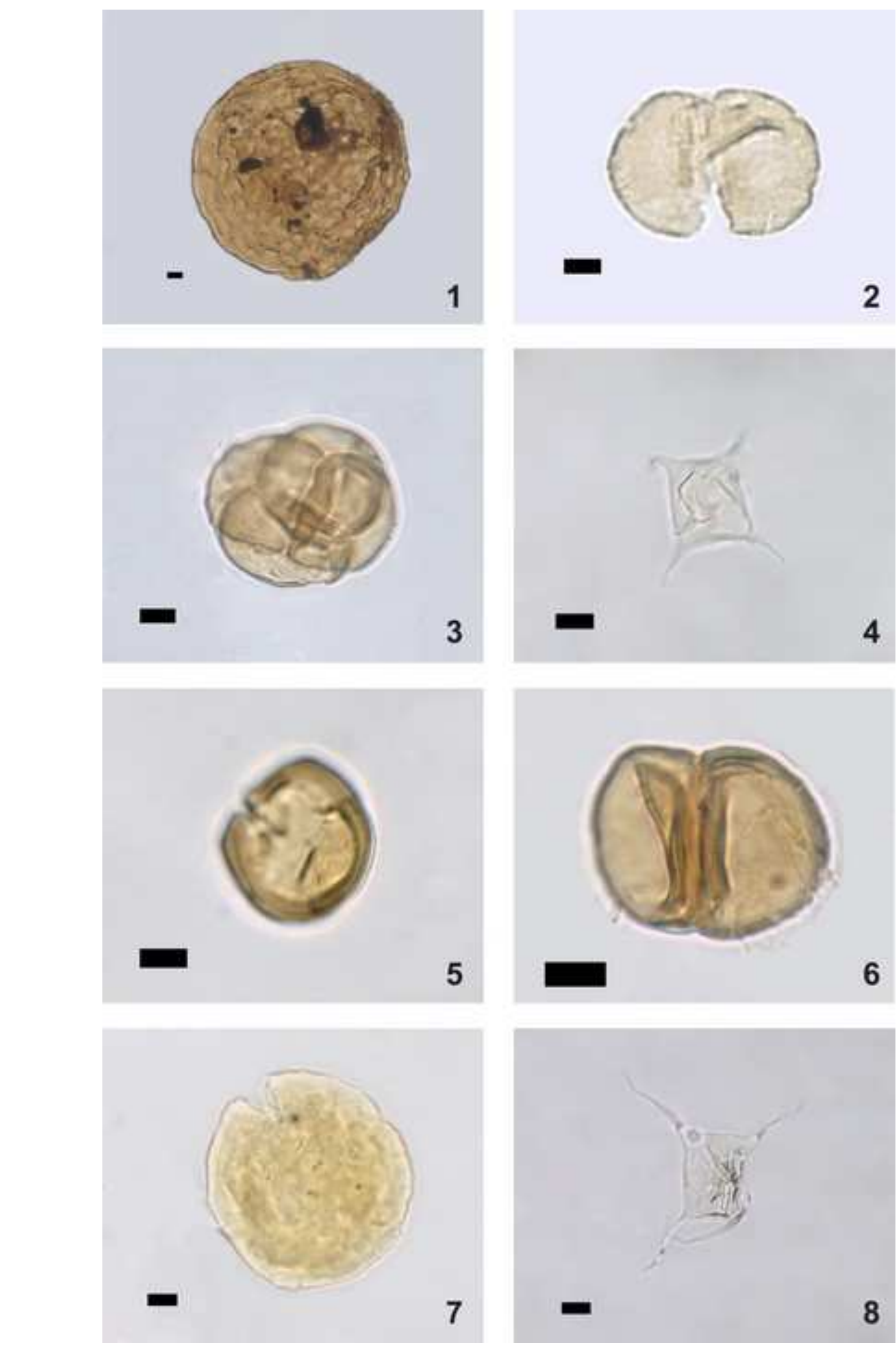

6 

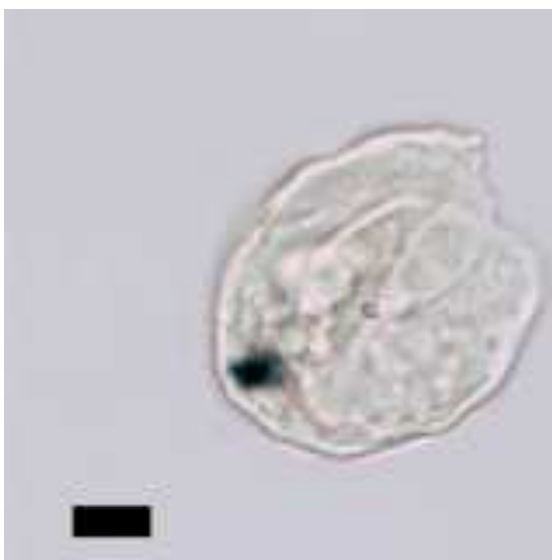

1
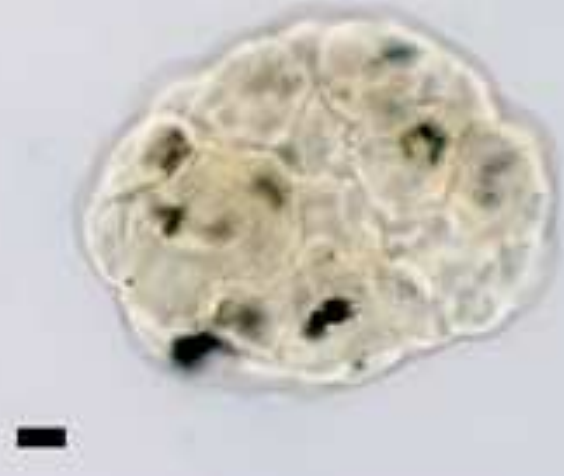

2
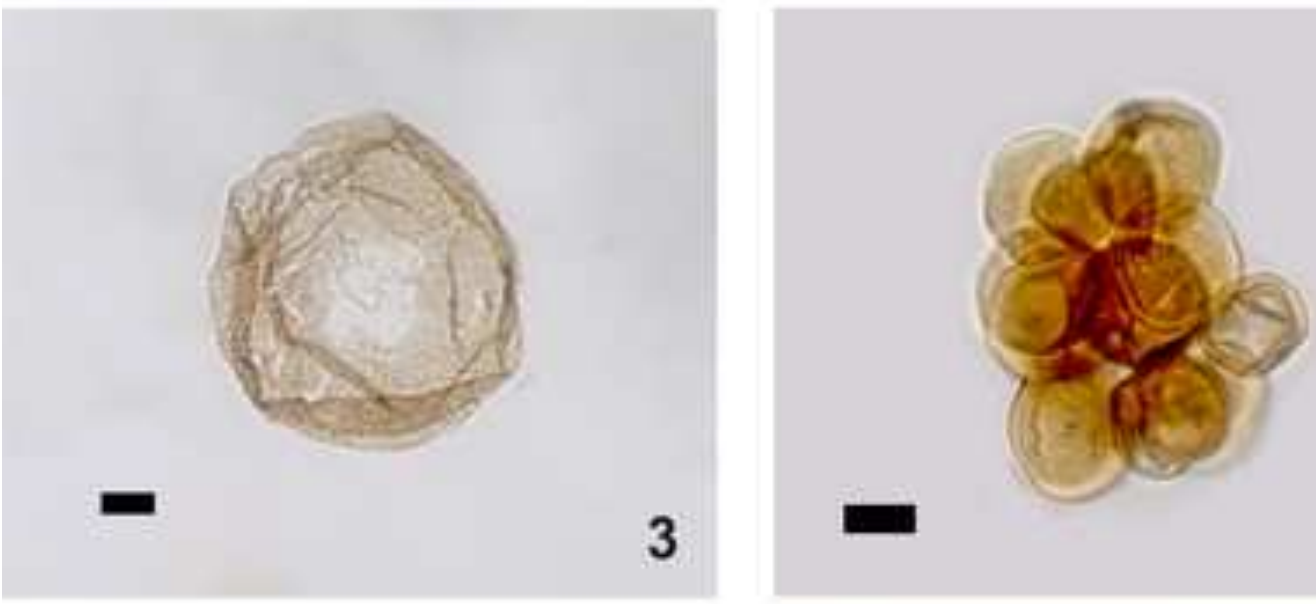

4

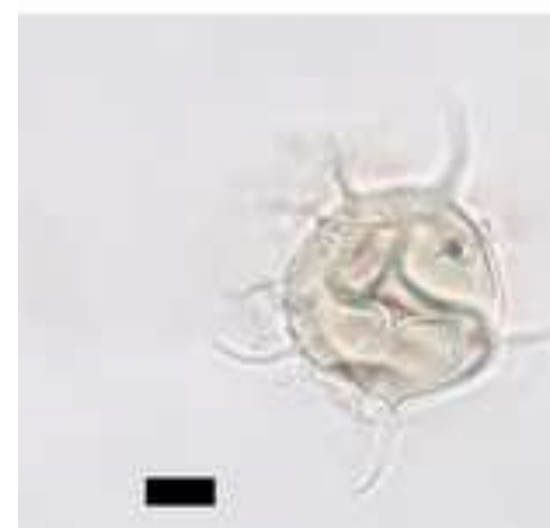

5

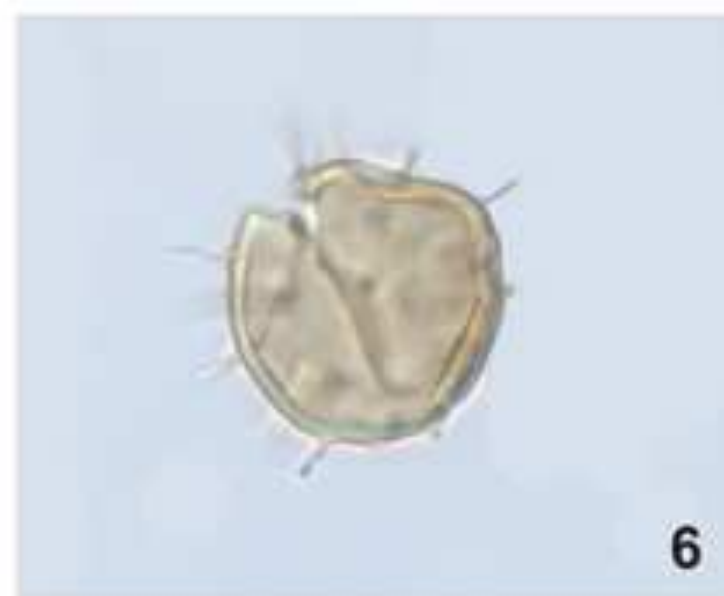

5

6
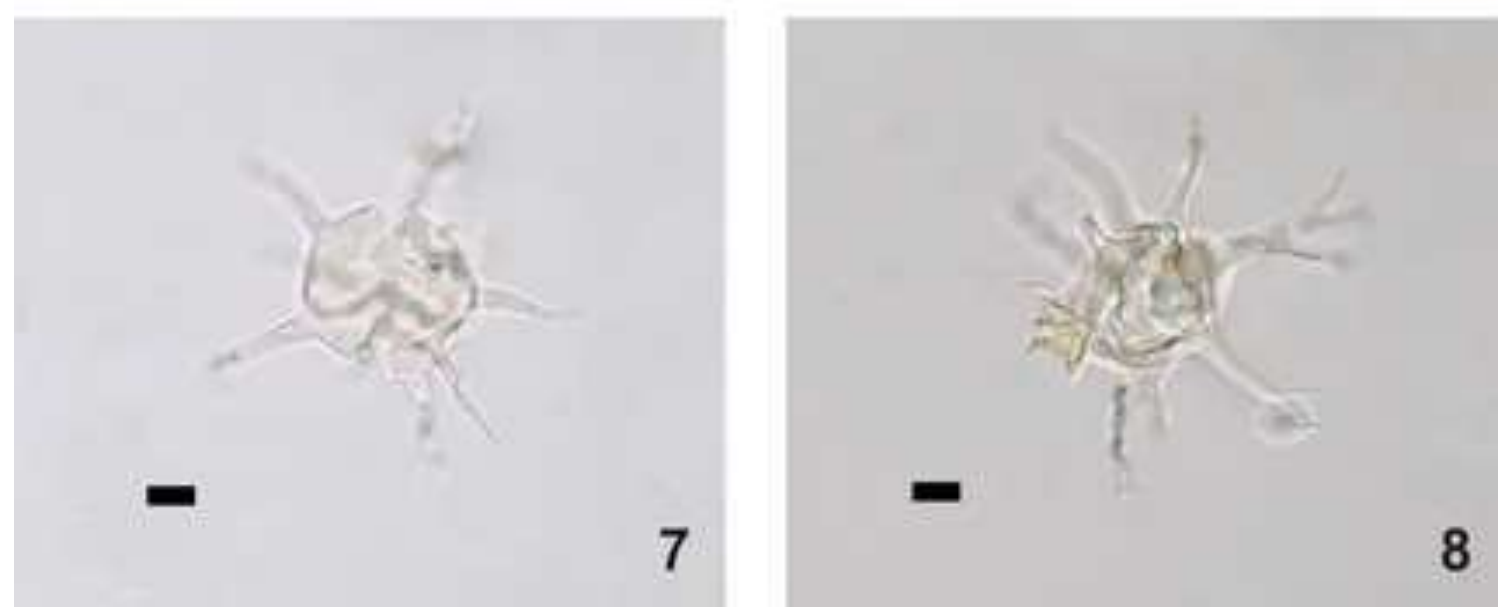

Plate 3

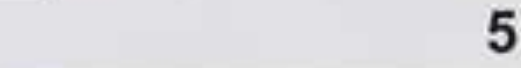



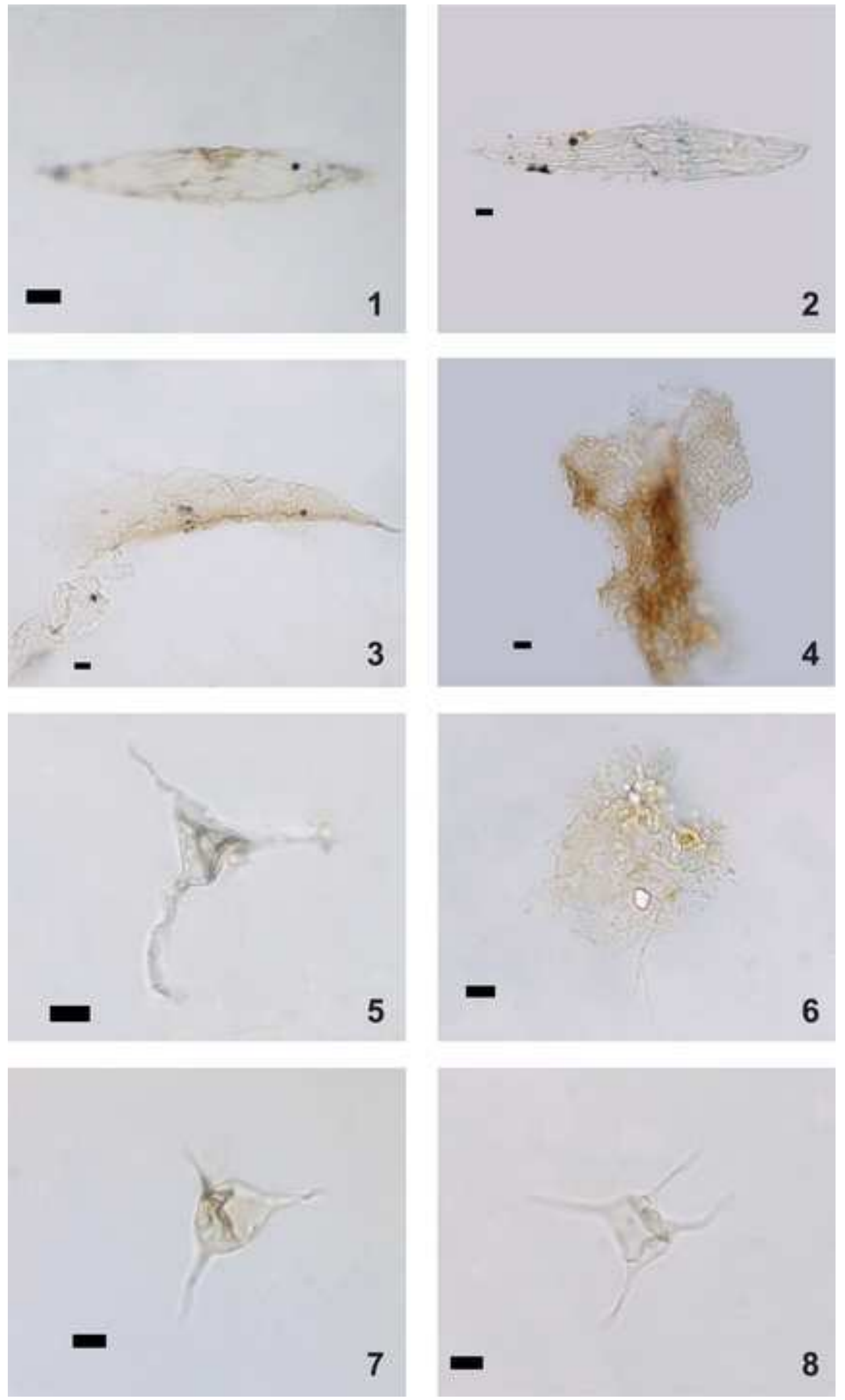

4 
Plate 5
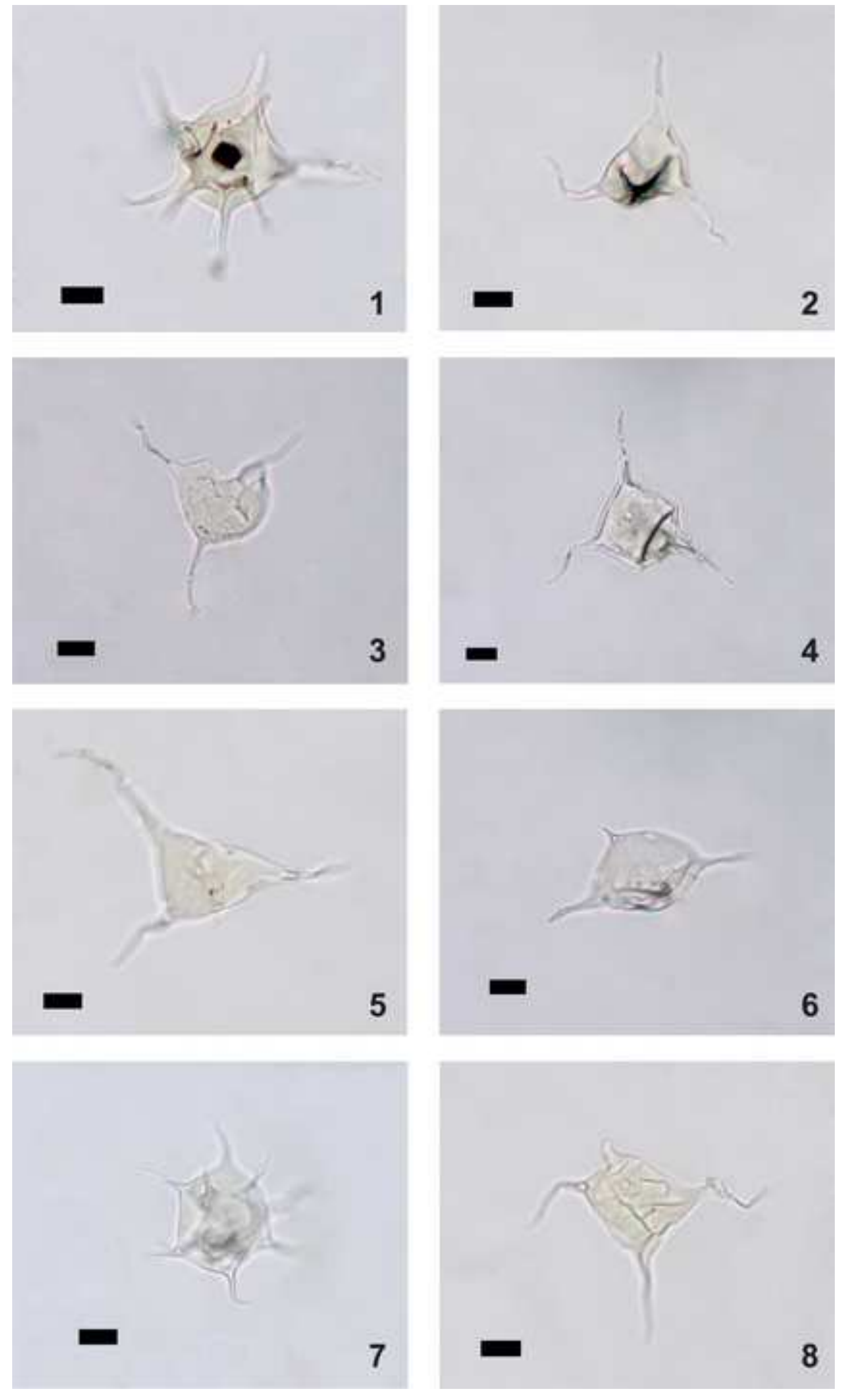

5 

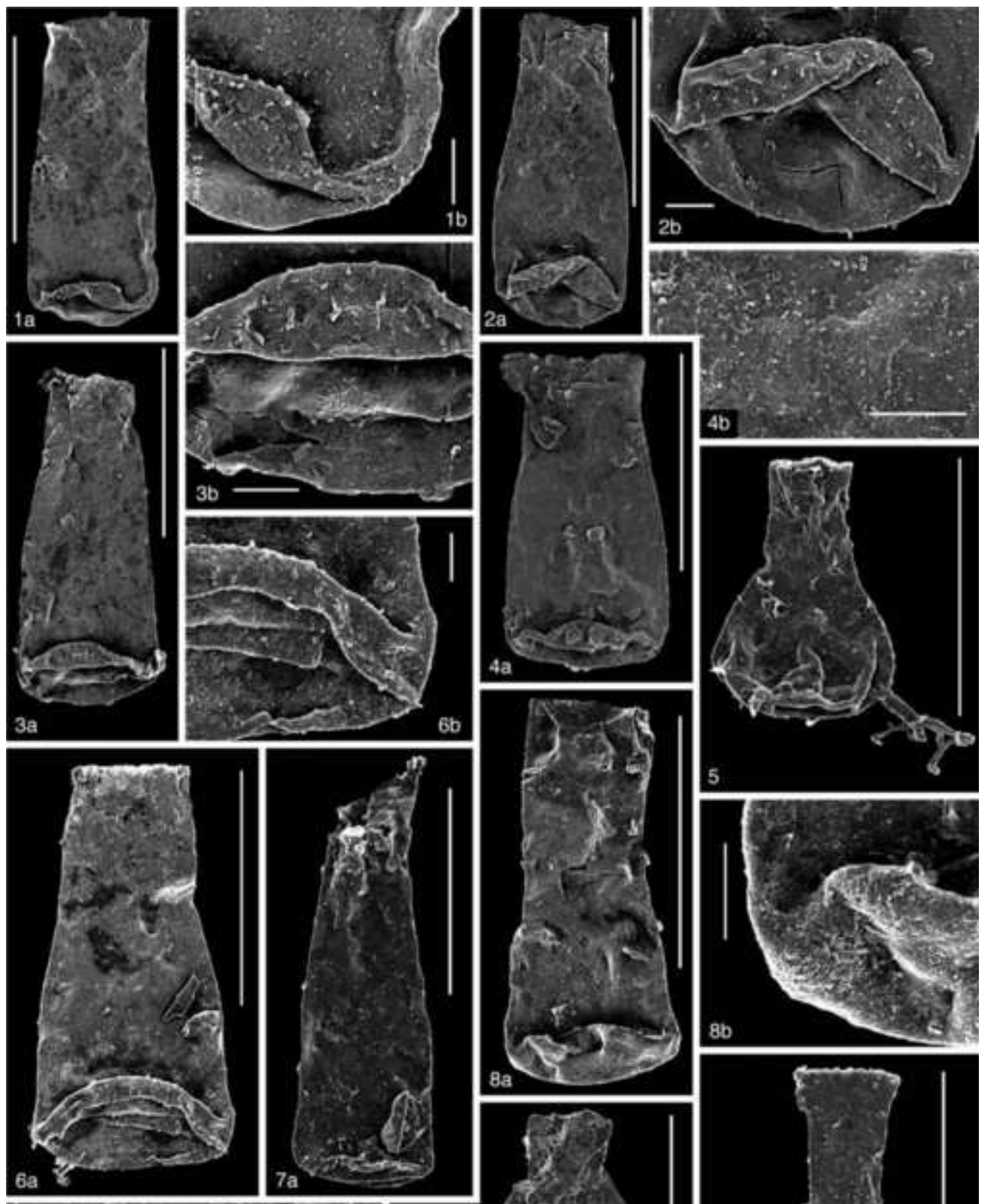

$4 b$
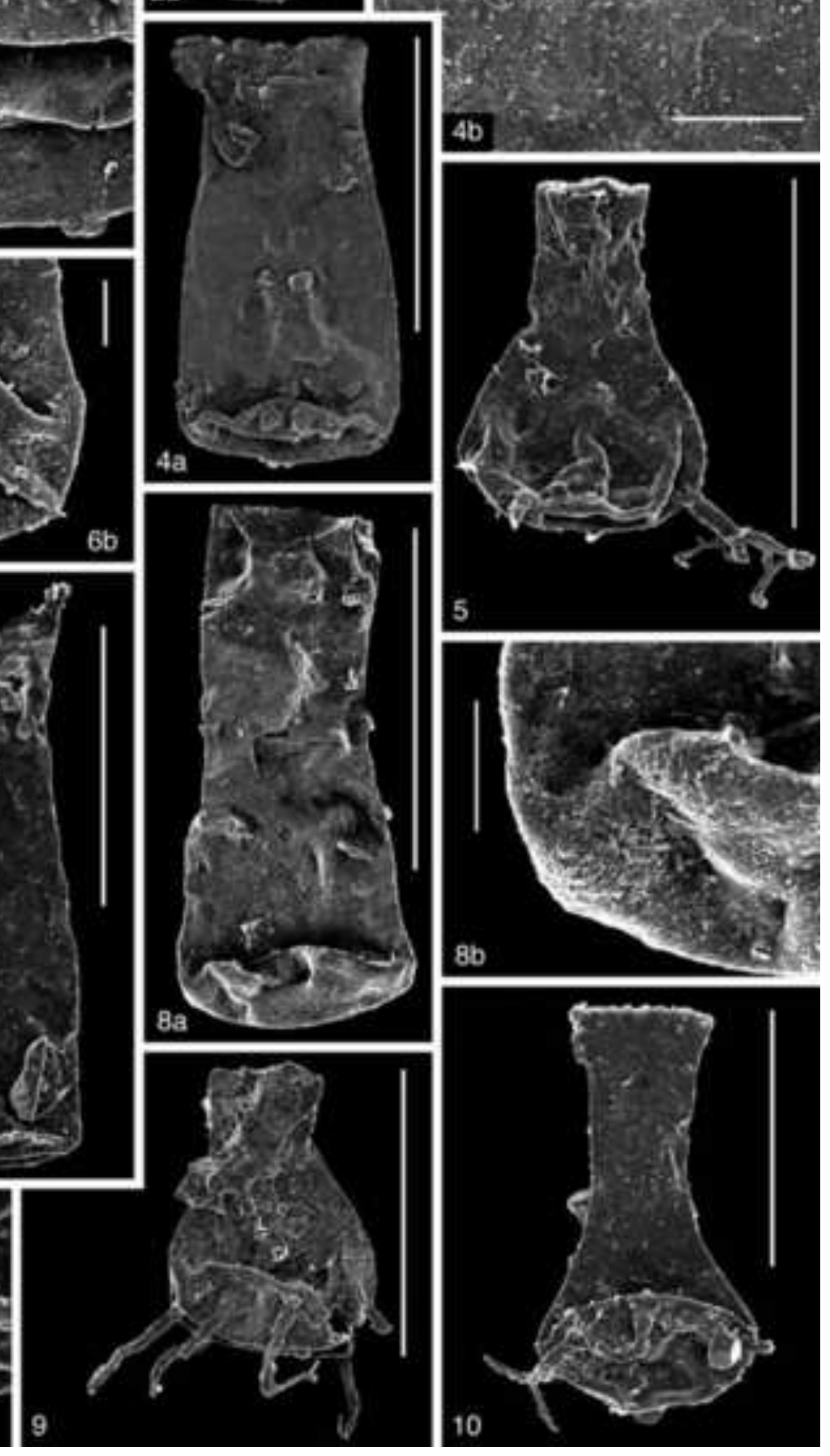
Plate 7

Click here to download high resolution image
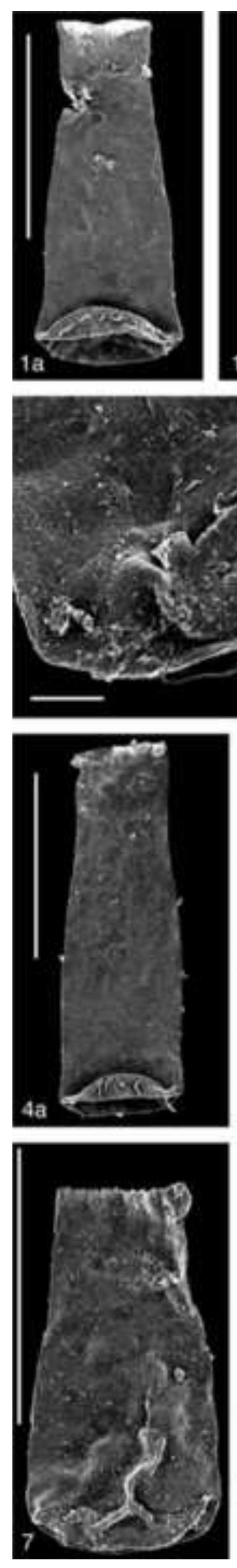
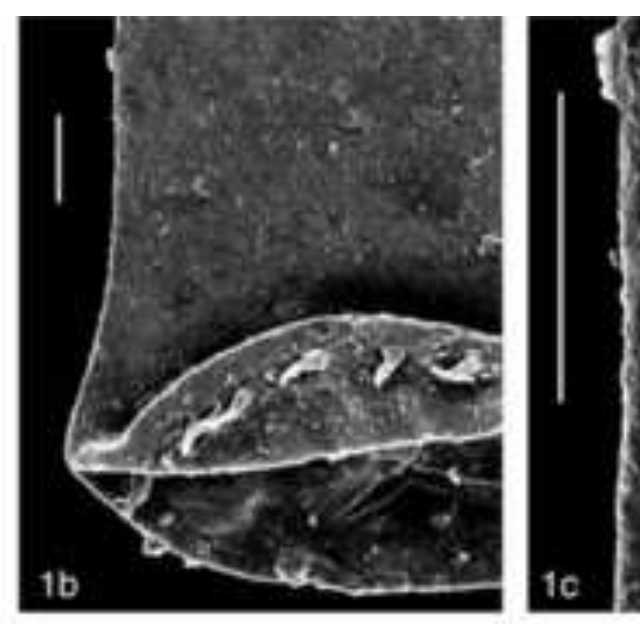

10
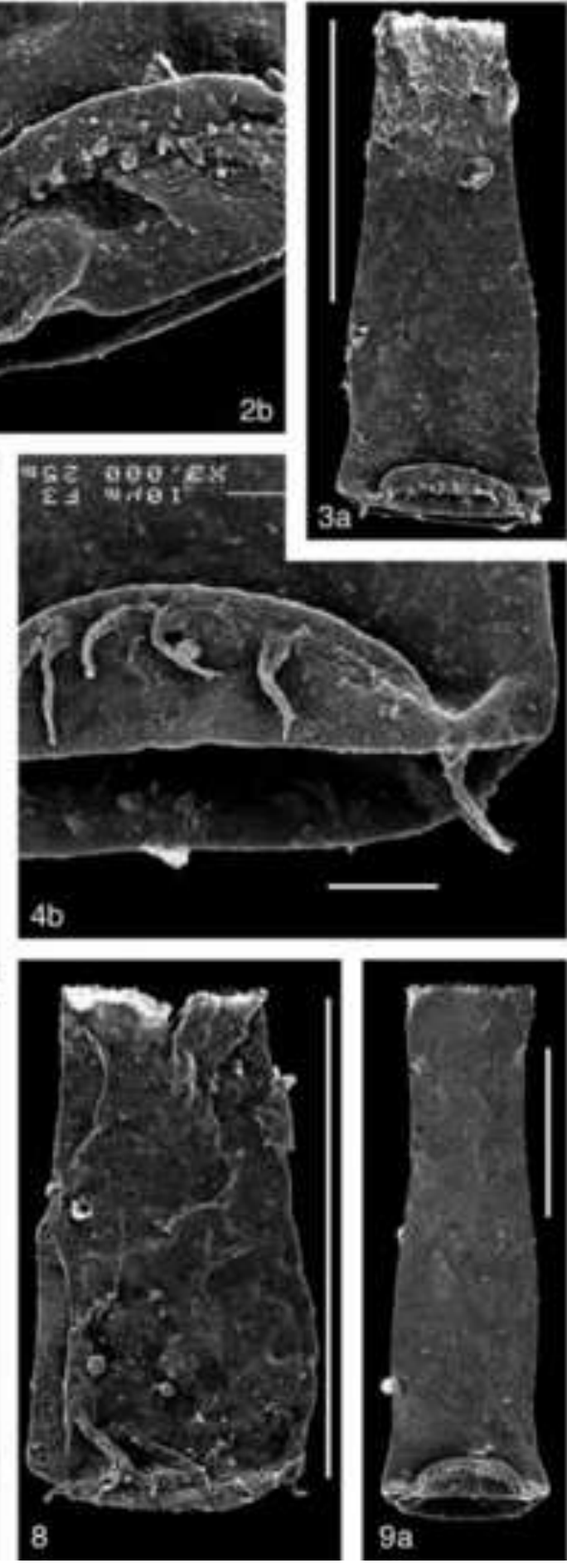
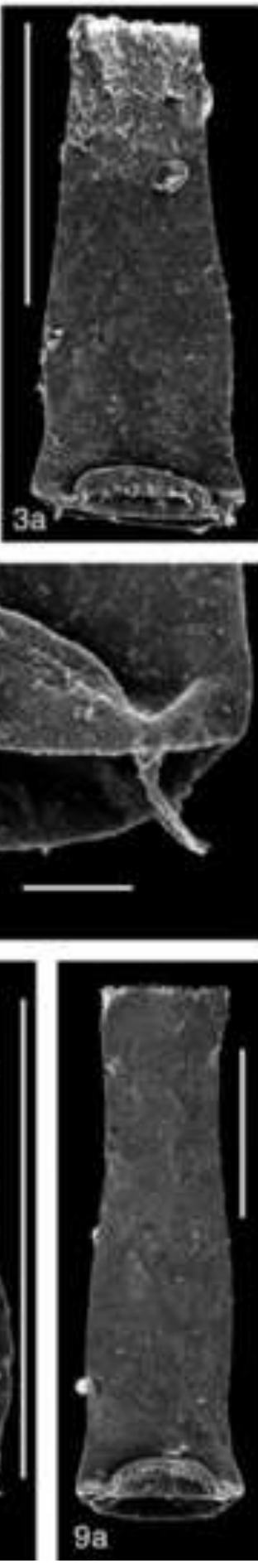
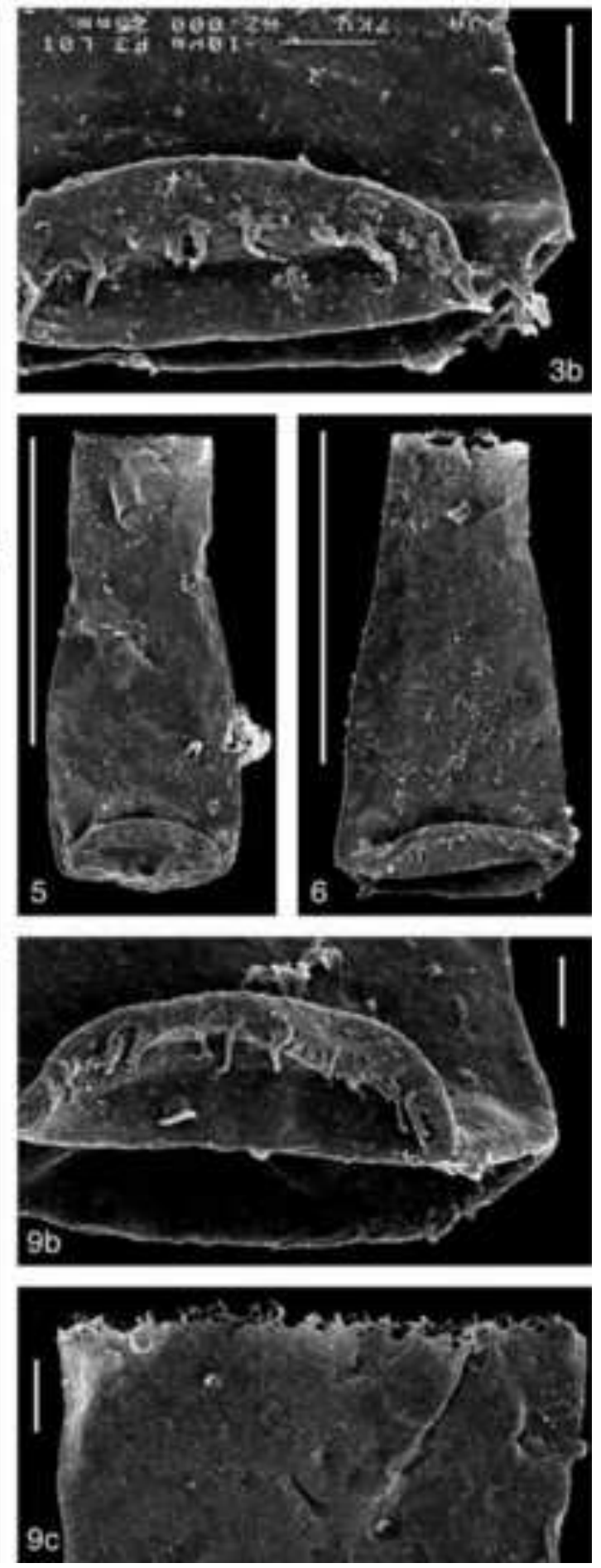
Plate 8

Click here to download high resolution image
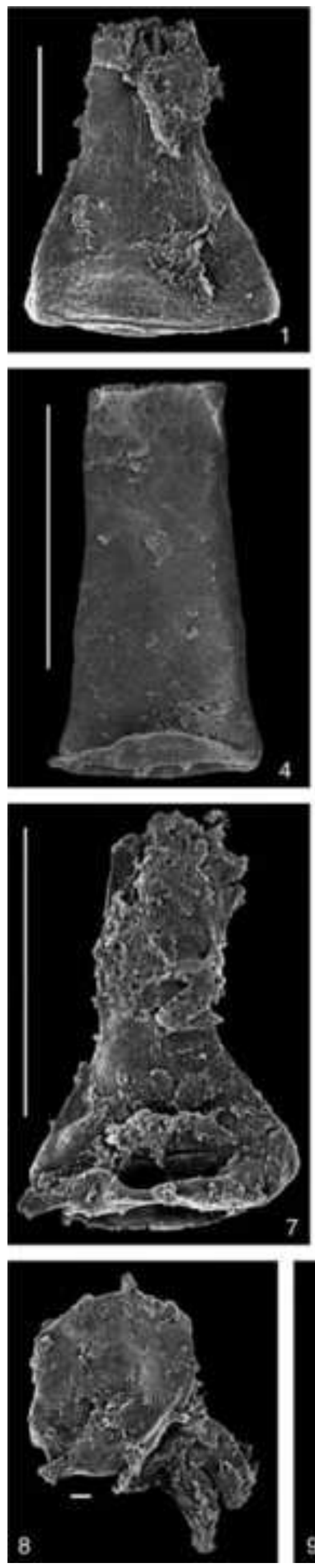
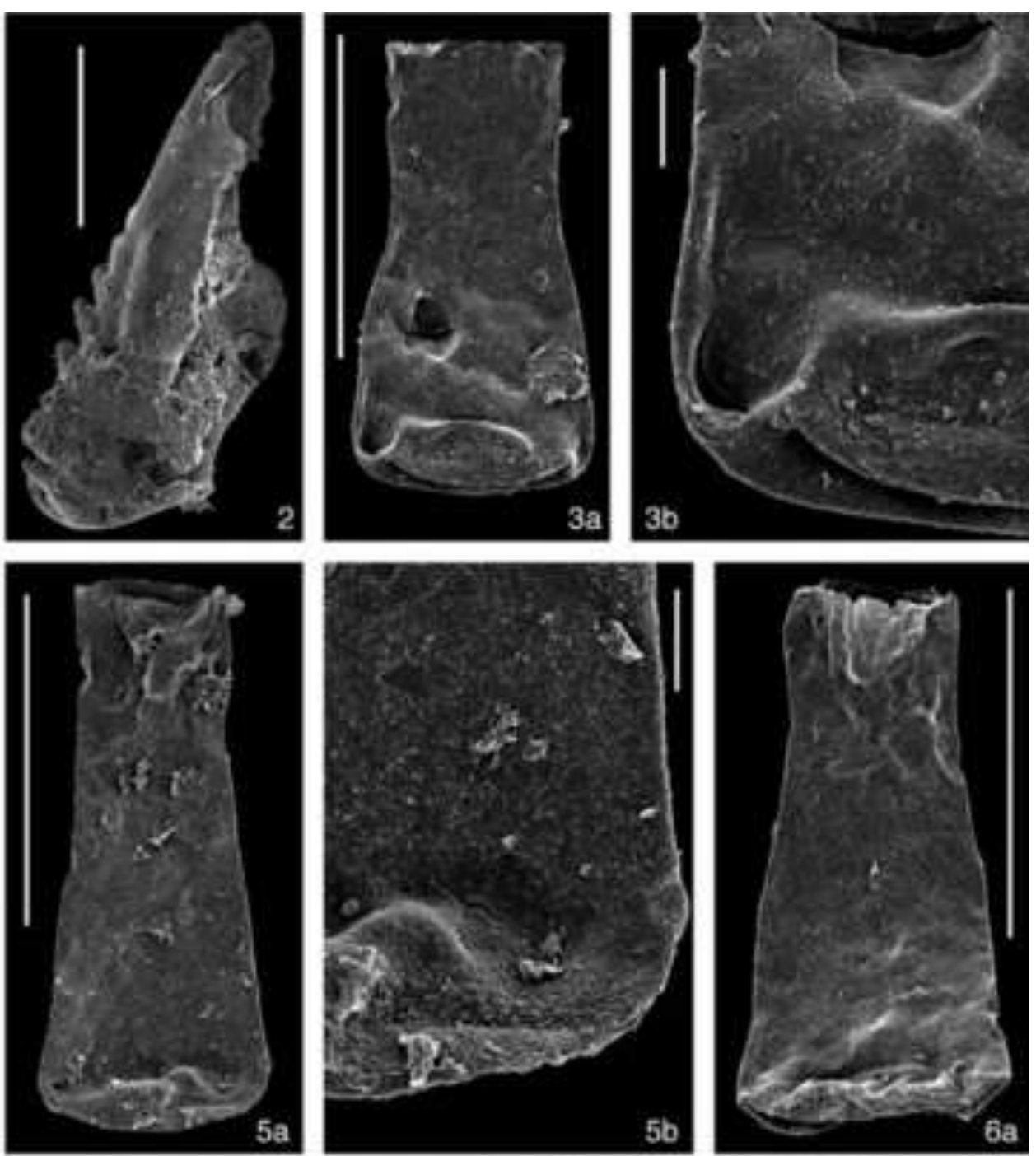

$5 b$

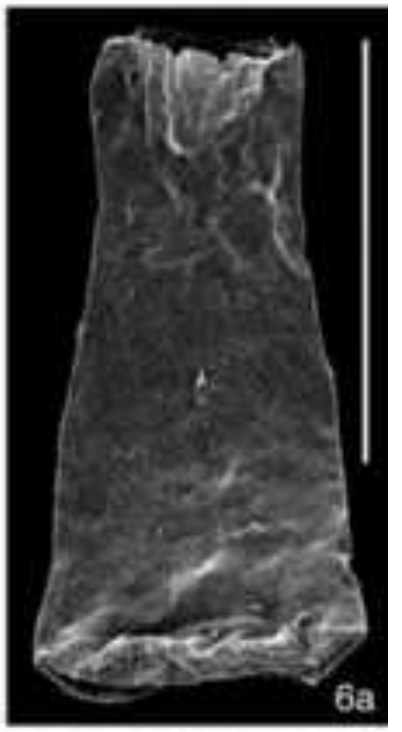

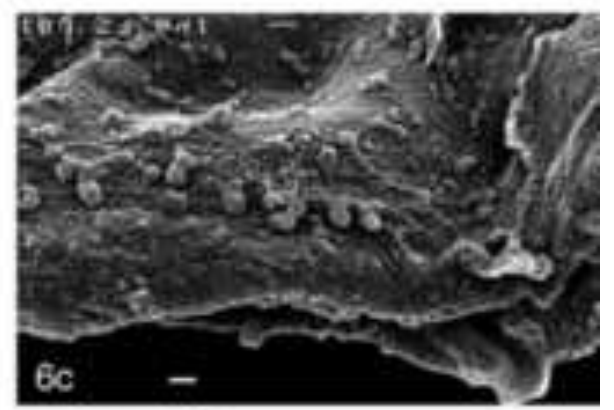

66
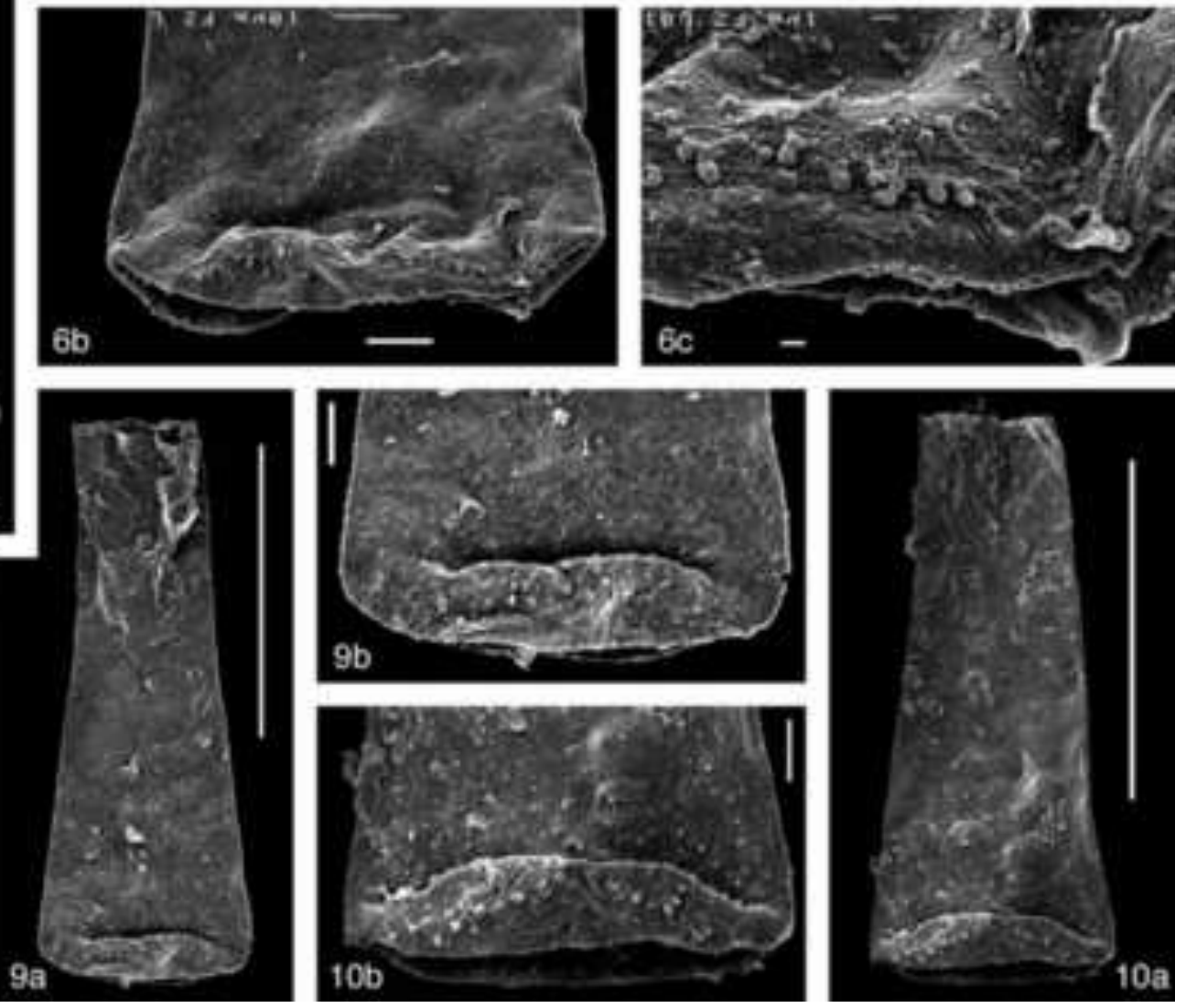
Plate 9

Click here to download high resolution image
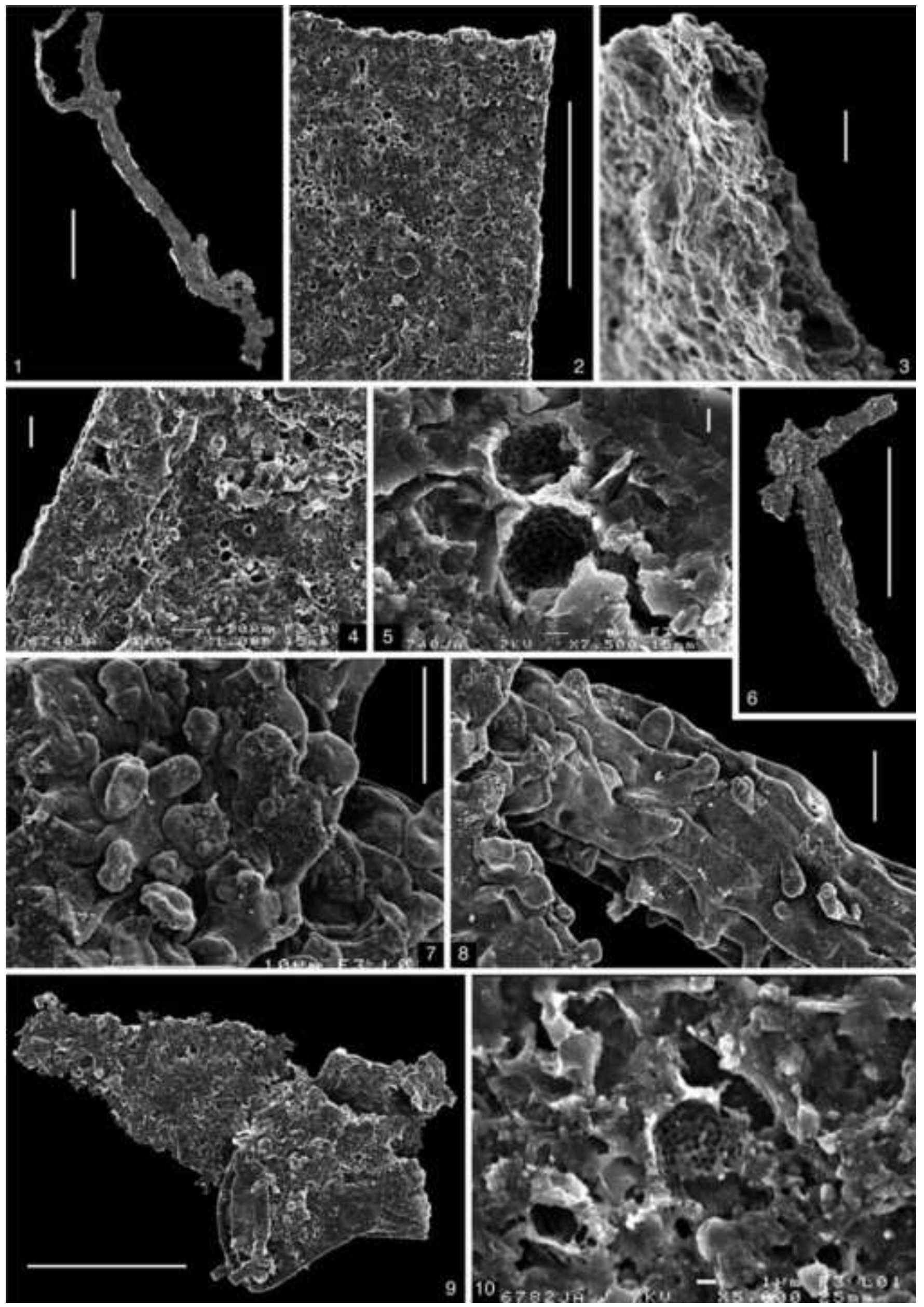

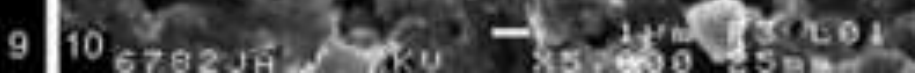




\section{Plate 10}

Click here to download high resolution image
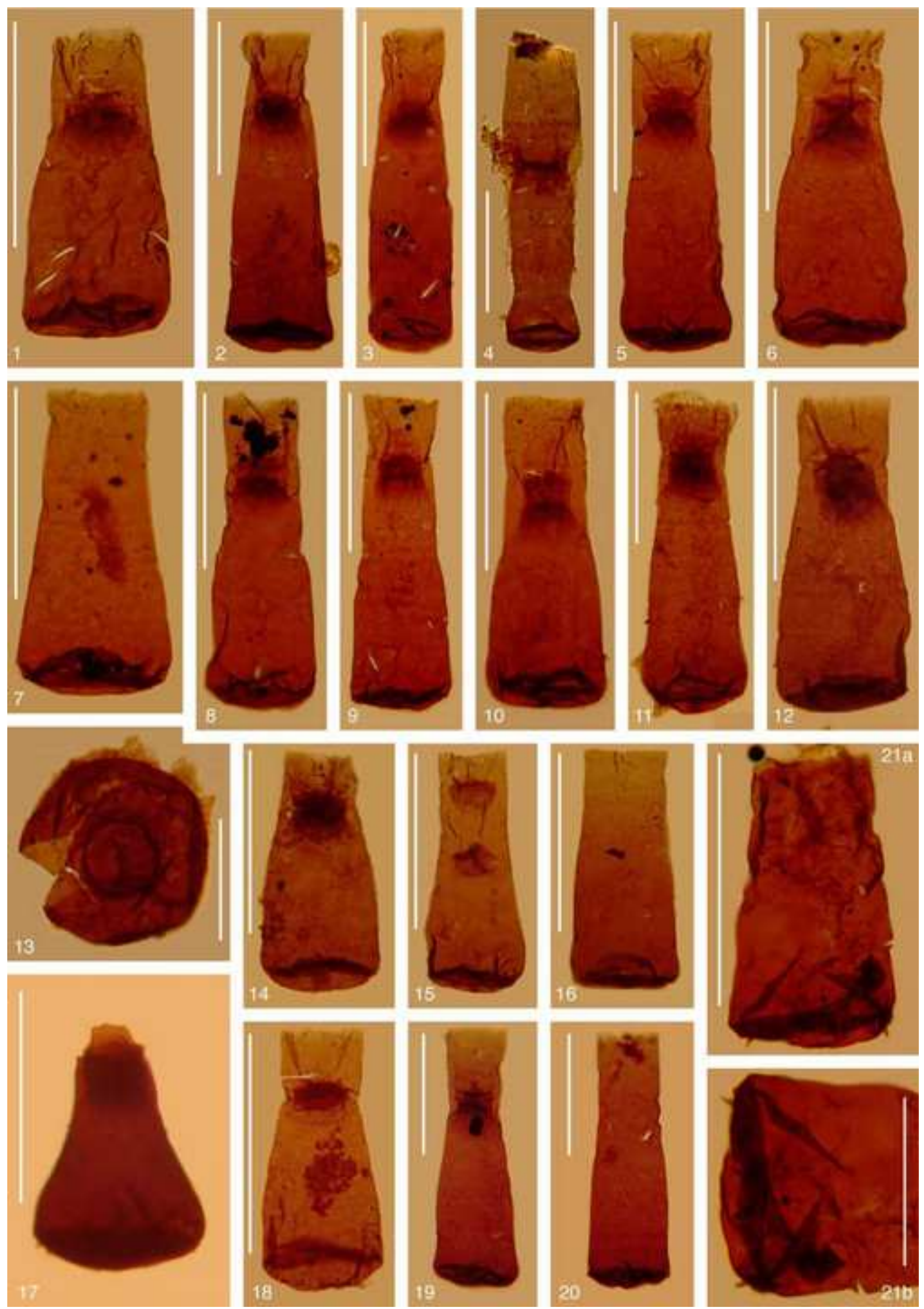


\section{Plate 11}

Click here to download high resolution image
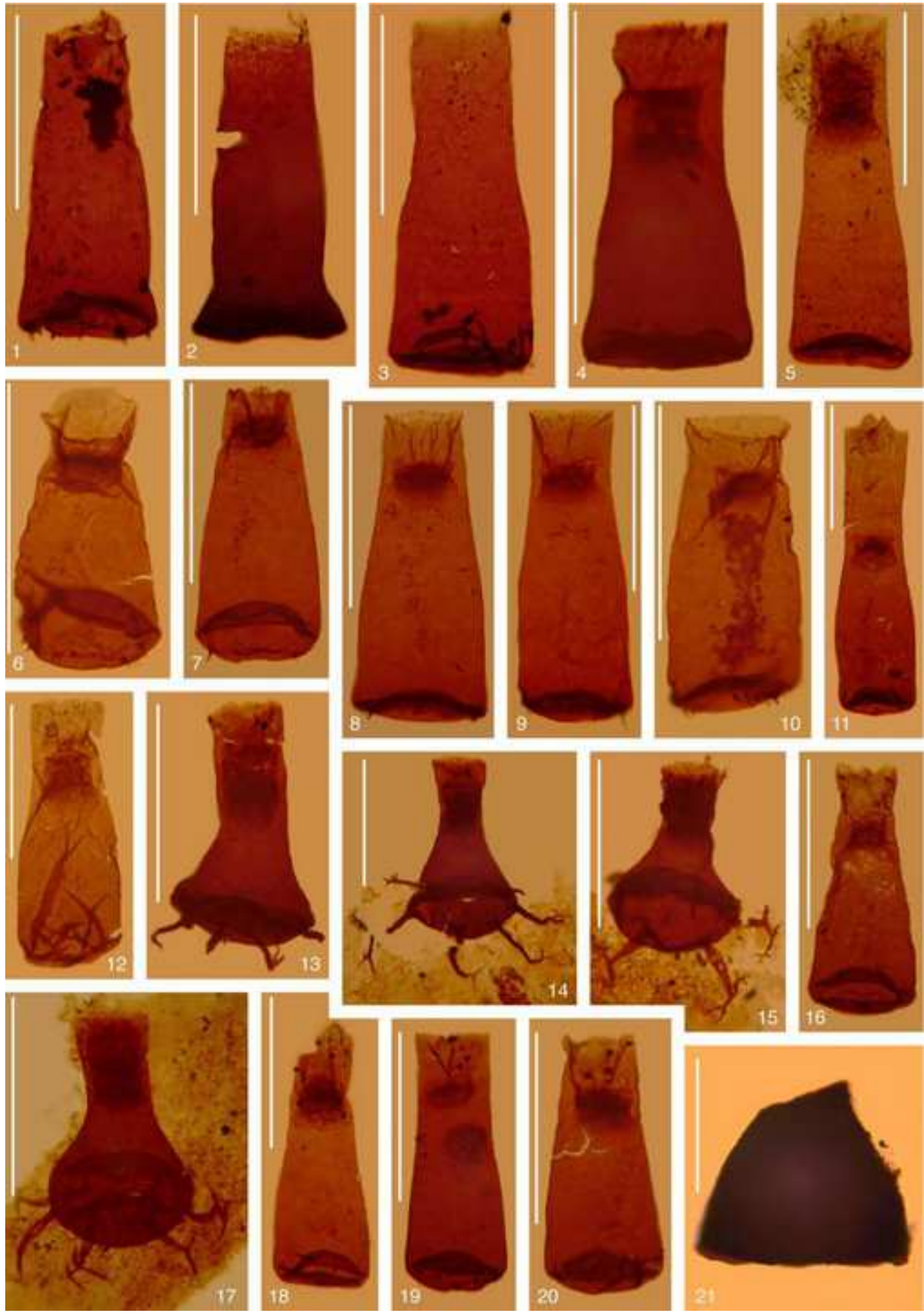
Plate 12

Click here to download high resolution image
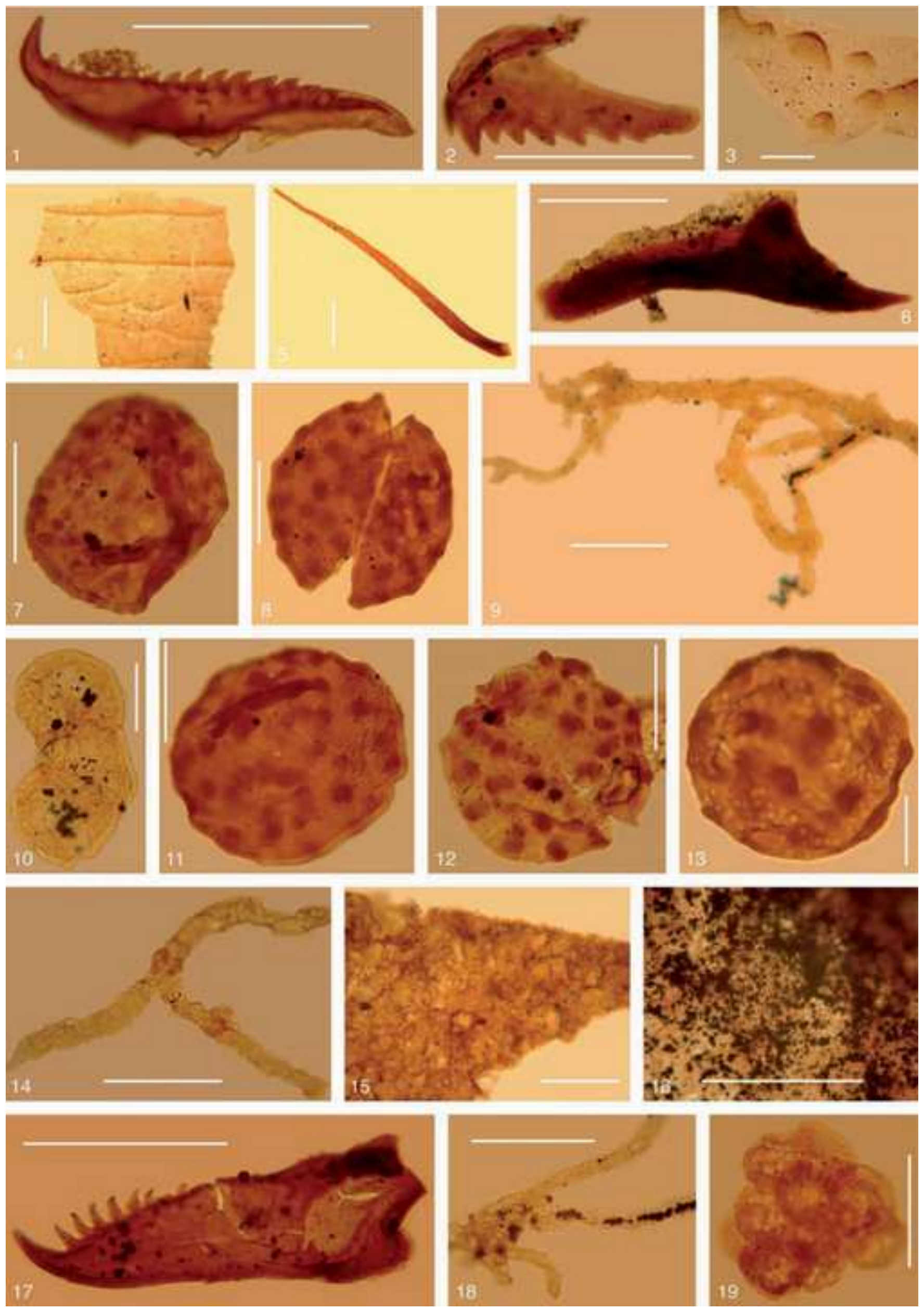